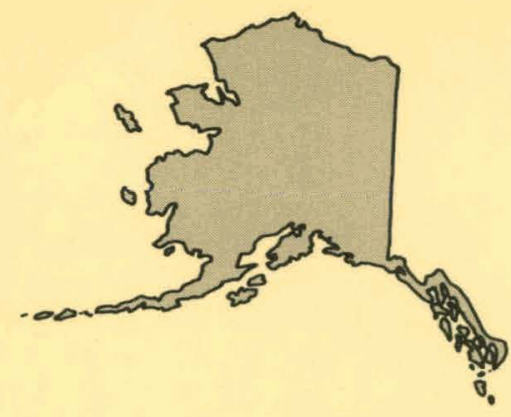

\title{
MASTER
}

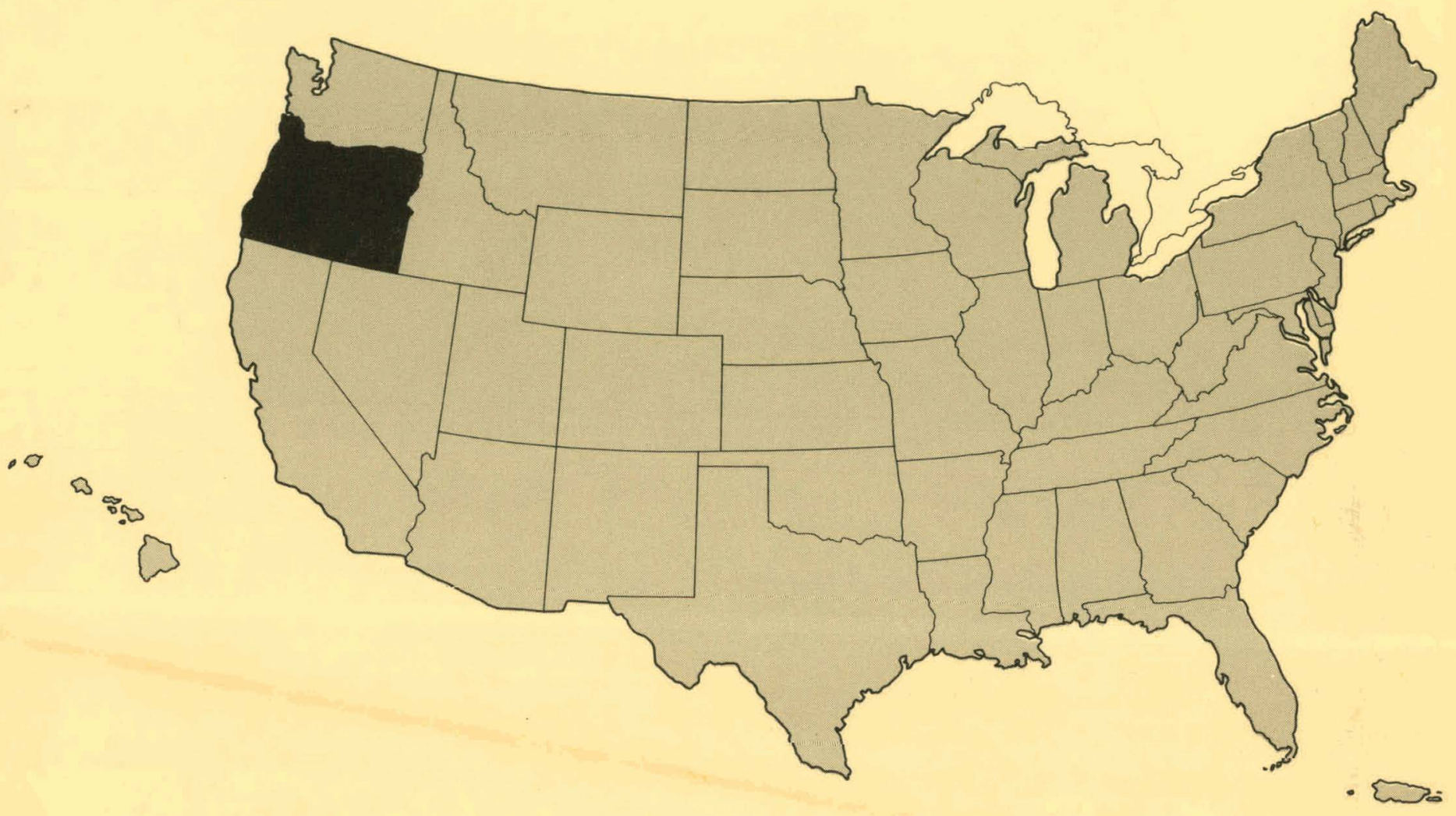

\section{Oregon State Briefing Book for Low-Level Radioactive Waste Management}




\section{DISCLAIMER}

This report was prepared as an account of work sponsored by an agency of the United States Government. Neither the United States Government nor any agency Thereof, nor any of their employees, makes any warranty, express or implied, or assumes any legal liability or responsibility for the accuracy, completeness, or usefulness of any information, apparatus, product, or process disclosed, or represents that its use would not infringe privately owned rights. Reference herein to any specific commercial product, process, or service by trade name, trademark, manufacturer, or otherwise does not necessarily constitute or imply its endorsement, recommendation, or favoring by the United States Government or any agency thereof. The views and opinions of authors expressed herein do not necessarily state or reflect those of the United States Government or any agency thereof. 


\section{DISCLAIMER}

Portions of this document may be illegible in electronic image products. Images are produced from the best available original document. 
DOE/IN $101570--T 47$

i

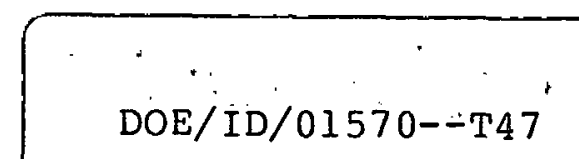

NUS 3635B

DE82 015275

\title{
OREGON STATE BRIEFING BOOK \\ LOW-LEVEL RADIOACTIVE,WASTE MANAGEMENT
}

Prepared for

EG\&G Idaho, Inc.

under

Subcontract No. K-5108

This book was prepared as an account of work sponsored by an agency of tha United States Government.

Neither tho United States Government nor any agency thereol, nor any of their employees, makes any

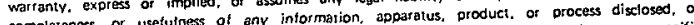

completentess. or usels wosuld not intringe privately owned rights, Reference herein to any specific

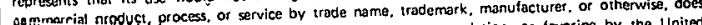

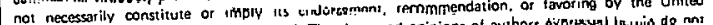

States Government or any agency thereof. The views and opinions of authars exprtsst.
necessarily state or reflect those of the United States Government or any agency thereof.

\author{
Prepared by \\ NUS Corporation \\ 4 Research Place \\ Rockville, Maryland 20850.
}

ROTICE

PORTIONS OF THIS REPOR'I ARE ILIEGIDLE. $X$ t

has been reproduced from the best availablo

copy to permit the broadest possible avail-

December 1980

ability.

MN ONLY

This report was prepared as an account of work sponsored by the United States Government. Neither the United States nor the Department of Energy, nor any of their employees, nor any of their contractors, subcontractors, or their employees, makes any warranty, express or implied, or assumes any legal liability or responsibility for the accuracy, completeness, or usefulness of any information, apparatus, product, or process disclosed, or represents that its use would not infringe privately owned rights. 
$\underline{\text { Page }}$

Title Page

Table of Contents

List of Figures

iv

List of Tables

$\mathbf{v}$

\section{Section}

1. Introduction

2. Overview of Low-Level Radioactive Waste

Management Practices

3. Demography 3-1

3.1 Location 3-1

3.2 Population $3-1$

3.3 Economy 3-2

3.3.1 Major Business Sectors 3-2

3.3.2 Employment and Per capita Incume 3-8

3.3.3 Gross State Product 3-8

3.4 Agriculture 3-13

3.5 Schools and Hospitals 3-13

4. Governmental and Public Aspects 4-1

4.1 Major Political Parties. 4-1

4.2 Congressional Representatives 4-1

4.3 State Government $\quad 4-2$

4.3.1 Executive Branch 4-2.

4.3.2 Legislative Branch 4-15

4.3.3 Judicial Branch 4-18

4.3.4 Statutory Regulations 4-19 
TABLE OF CONTENTS (concluded)

Section

Page

4.4 Federal Activities in the State of Oregon

4.5 Interest Groups

4-19

4.6 Printed Media

4-20

5. Survey Methodology

5-1

6. Use of. Commercial Low-level Waste Facilities 6-1

6.1 Response to Survey 6-1

6.2 Sources of Shipped Waste 6-2

6.2.1 Distribution by Type of Facilities 6-2

6.2.2 Origins of Radioactivity Resulting 6-2

in Shipped Wastes

6.3 Volume of Shipped Waste 6-2

6.4 Activity of Shipped waste 6-3

6.5 Physical Characteristics of Shipped Waste 6-3

\section{APPENDICES}

A. Radioactive Material Licenses in the State of Oregon A-1

B. State Laws and Regulations Applying to Radioactive B-l Waste Management in Oregon

C. Representative Newspaper Articles Related to Radiation . C-1 Issues and Radioactive Waste Management. 
3-1 Counties of the State of Oregon $3-3$

3-2 Standard Metropolitan Sțatistical Areas in Oregon 3-4

3-3 Population Density by County: Oregon, 1975 3-7

3-4 Percent of Gross Product by Industry: United States and . 3-14 Oregon, 1978

4-1 Oregon Congressional Districts

4-2 List of State Agencies 4-9

4-3 Oregon Senatorial Districts 4 4-16

4-4 Oregon Representative Districts $\quad 4-17$

5-1 Survey Form $\quad$ 5-2

5-2 Transmittal Letter for Survey Form . 5-4

5-3 General Instructions . 5-5

5-4 Form Used for Tabulation 5-6 
LIST OF TABLES

Table

Page

$1-1$

Commercial Shallow Land Burial sites

$1-2$

$1-2$

Total U.S. Waste Volumes Buried at Commercial

$1-3$

Burial sites (Cubic Meters)

Use of Commercial Low-level Waste Repositories

$2-4$

$2-2$

Disposal Practices Used for Low-Level Radioactive Wastes

$2-5$

$2-3$

Sources of Radioactivity Requiring Disposal

$2-6$

$3-1$

Standard Metropolitan Statistical Areas in the

3-5

state of Oregon

Major Economic Activities in Oregon by County

3-6

$3-3$

U.S. and Oregon Labor Force, 1976 and 1978

$3-9$

Per Capita Income in the U.S. and Oregon for

$3-9$

Selected Years

Persons Living Below the Poverty Level in the U.S: and Oregon, 1969,1975

Gross National Product, U.S. Employee Compensation

3-10 and Ratio of Product to Compensation, by Industry Product, by Industry, for Oregon

6-1 Response to Direct Mail Survey, 6-5

6-2 Type of Facilities Shipping Low-Level waste 6-6.

6-3 Origin of Radioactivity Resulting in Shipped Wastes 6-7

6-4 Volume of Shipped Waste $\quad 6-8$

6-5 Projected Change in Volume of Shipped waste 6-9 


\section{LIST OF TABLES (concluded)}

Table

Page

6-6 Activity of Shipped Wastes

$6-10$

6-7 Radionuclides in Shipped Waste

$6-11$

6-8. Onsite Processing of Shipped Waste

6-12

6-9

Shipping Container Used

$6-13$

$6-10$

Physical Form of Shipped Waste

$6-14$ 


\section{INTRODUCTION}

This Oregon State Briefing Book for Low-Level Radioactive Waste Management has been prepared to assist in the orderly planning and implementation of providing adequate safe low-level radioactive waste disposal facilities. The Oregon state Briefing Book is one of a series of briefing books being prepared that will provide background information of waste management practices in all states.

of six commercial low-level radioactive waste disposal sites that have operated within the United States (see Table 1-1), only three are currently accepting additional wastes. Of these three, two sites have been closed intermittently because of various irregularities in disposal and shipping operations. (1) Table 1-2 presents the total waste volumes that have been disposed of at commercial sites during the period 1962 through 1979. In 1979, approximately 79 percent of the wastes were shipped to the South Carolina site.

Projections of total national low-level radioactive waste generation and capacity of existing comercial disposal facilities indicate that if no change in present practices or trends occur, the current disposal sites could be filled by the mid1990s. However, recent proposed limitations of yearly burial quantities to be accepted by disposal sites located in South Carolina and Washington State will reduce the availability of burial space. South Carolina's limit on waste receipts will be reduced to 100,000 cubic feet per month by October 1981 and a Washington state initiative will restrict use of the Richland comercial disposal site after July 1, 1981. Therefore, it is possible that by the mid-1980s there would be more waste volume generated per year than could be buried. (1)

Section 2 of this Briefing Book presents an overview of past and present low-level radioactive waste management practices within the state of oregon. Section 3 identifies those demographic and economic factors and trends that affect or can be related to the quantity and nature of low-level radioactive wastes within the state 
COMMERCIAL LOW-LEVEL RADIOACTIVE

WASTE DISPOSAL SITES (1)

\section{Location}

Maxey Flats, Ry.

Beatty, Nev.

Sheffield, Ill.

Richland, Wash.

Barnwell, S.C.

West Valley, N.Y.
Year first

licensed

1962

1962

1967

1965

1971

1963
Site
operator

Nuclear

Engineering

Company

Nuclear
Engineer ing
Company

Nuclear Engineering Company

Nuclear Engineering Company

Chem-Nuclear Systome, Ine.

Nuclear Fuel Services
Licensing Year

authority closed

State $\quad 1977$

State Open

NRC

1978

state

and

NRC

State

and

NRC

State

and

NRC
Open

Open

1975 
TABLE 1-2

TOTAL U.S. WASTE VOLUMES BURIED AT COMMERCIAL BURIAL SITES (CUBIC METERS)

\begin{tabular}{|c|c|c|c|c|c|c|c|}
\hline \multirow[b]{2}{*}{ Year } & \multicolumn{6}{|c|}{ Burial Site } & \multirow{2}{*}{$\begin{array}{c}\text { National } \\
\text { annual } \\
\text { total }\end{array}$} \\
\hline & Rentucky & Nevada & $\begin{array}{c}\text { South } \\
\text { Carolina }\end{array}$ & Illinois & $\begin{array}{l}\text { New } \\
\text { York } \\
\end{array}$ & Washington & \\
\hline 1962 & - & 1,861 & - & - & - & - & 1,861 \\
\hline 1963 & 2,206 & 3,512 & - & - & 522 & - & 6,240 \\
\hline 1964 & 3,872 & 2,836 & - & - & 6,388 & - & 13,096 \\
\hline 1965 & 5,751 & 1,988 & - & - & 4.717 & 668 & 13,124 \\
\hline 1966 & 5,556 & 3,533 & - & - & 4,697 & 2,402 & 16,188 \\
\hline 1967 & 7,820 & 3,206 & - & 2,527 & 4,946 & 870 & 19,369 \\
\hline 1968 & 8,177 & 3,576 & - & 2,713 & 4,505 & 669 & 19,640 \\
\hline 1969 & 10,353 & 4,282 & - & 2,012 & 4,274 & 438 & 21,359 \\
\hline 1970 & 12,520 & 4,131 & - & 2,825 & 5,096 & 423 & 24,995 \\
\hline 1971 & 13,171 & 3,584 & 1,171 & 4,430 & 6,362 & 584 & 29,302 \\
\hline 1972 & 15,577 & 4,301 & 3,757 & 5,956 & 7,054 & 654 & 37,299 \\
\hline 1973 & 10.072 & 4,076 & 15,839 & 8,524 & 7,497 & 1,033 & 47,041 \\
\hline 1974 & 8,897 & 4,103 & 18,244 & 12,373 & 8,574 & 1,411 & 53,602 \\
\hline 1975 & 17,109 & 4,943 & 18,072 & 14,116 & $1,889 *$ & 1,500 & 57,629 \\
\hline 1976 & 13,783 & 3,864 & 40,227 & 13,480 & $\star$ & 2,867 & $7.4,221$ \\
\hline 1977 & $423 * \star$ & 4,742 & 46,563 & 17,643 & $\star$ & 2,718 & 72,089 \\
\hline 1978 & ** & 8.827 & 61,566 & $102 \star * *$ & $\star$ & 7,422 & 77,917 \\
\hline $1979^{(2)}$ & $\star \star$ & 6,491 & 63,433 & $* * *$ & $\star$ & 9,980 & 79,914 \\
\hline Total & 135,287 & 73,856 & 268,882 & 86,701 & 66,521 & 33,639 & 664,886 \\
\hline
\end{tabular}

*Receipt and burial of wastes were suspended by Nuclear Fuel Services on $3 / 11 / 75$. $*$ Receipt and burial of wastes were suspended on $12 / 27 / 77$.

$\star \star$ Receipt and burial of wastes were suspended on $4 / 8 / 78$. 
of oregon. Section 4 presents an overview of Oregon's state government and identifies the government institutions and agencies with statutory or other responsibilities affecting the generation, handling, and disposal of radioactive wastes within the state. The identities and attitudes of state officials and other organizations impinging on this issue are presented in the text and, where possible, in available representative print media. Section 5 presents the methodology employed for conducting a direct mail survey of radioactive material licensees within the state to obtain basic information on disposal practices. The results of this survey are presented in section 6 for that information dealing with wastes shipped to comercial disposal facilities. 


$$
1 \text { REFERENCE }
$$

1. William F. Bolcomb, Inventory (1962-1978) and Projections (to 2000) of Shallow Land Burial of Radioactive Wastes at Commercial Sites: An Update, Nuclear Safety, Vol. 21, No. 3, May-June 1980.

2. NUS Corporation, The 1979 State-by-State Assessment of Low-Level Radioactive Wastes Shipped to Commercial Burial Grounds, NUS 3440 , Revision 1, November 1980. 


\section{OVERVIEW OF LOW-LEVEI RADIOACTIVE WASTE MANAGEMENT}

Bistorically, the generation of low-level radioactive waste and the requisite disposal practices of licensees have received little focus from regulatory agencies, interest groups, and the facilities themselves. These wastes, including their creation and environmental impact, were judged to be less than paramount in light of the waste volumes and activities produced by irradiated reactor fuel and other high-level sources. Although comercial nuclear power reactors contribute a significant portion of low-level radioactive waste, other major categories of waste generators include medical, educational, and industrial facilities.

The State of Oregon is an Agreement State whereby all radioactive material licenses and waste disposal practices are under the conditions and regulations established by the state government. The specific controls and operational criteria follow, at minimum, those instituted by the federal government.

The only operating comercial nuclear reactor within the state of oregon is the Trojan unit, located 30 miles northwest of portland. Two additional reactors, Pebble Springs 1 and 2, are scheduled to become operational in 1988 and 1990 , respectively. No foderal nuclear facilities exist within the state of oregon.

Prior to the late 1960 s and early 1970s, low-level radioactive waste disposal practices typically consisted of onsite storage. In accordance with existing federal regulations, wastes were generally stored in above-ground buildings or buried in shallow trenches. Present trends in waste disposal include onsite storage and eventual release to sewer systems and combination with comon refuse after appropriate decay to exempt concentrations. Exempt concentrations, at minimum, follow parameters outlined in the Code of Federal Regulations, Section 10, Part 20.

The use of radioisotopes in medical diagnostic and therapeutic applications has increased as a result of relatively recent new applications and techniques in the medical field. Due to the short half-life of nuclides normally used for these purposes, the decay and release disposal method is frequently practiced. Other major facilities often seleot this mode of low-level radioactive waste disposal, if 
this option is feasible. As the availability of commercial repositories become limited and economically prohibitive parameters inpact the shipment of low-level radioactive waste, onsite decay is practiced with-increased incidence.

The economics of waste shipment to distant repositories is dictating an efficient managenent program with regard to volumes generated by each facility. Trends by generator facilities appear to be channeled towards volume reduction. Evaluations are ongoing by numerous facilities to effectively reduce the volume and subsequently the number of requisite annual shipnents of waste. These methods include the application of compaction, liquid evaporation, and waste solidification and incineration.

A total of 185 radicactive material licenses are in effect in oregon. Information on disposal practices was solicited from each license holder by a written questionnaire (see section 5.0). Appendix A presents the name and address of each license holder, the degree of response to the questionnaire, the type of facility, and whether they ship waste to a commercial disposal site. The degree of response was classified as follows:

$N$ indicates that no response to the written questionnaire was received.

1 indicates the licensee did respond and provided all appropriate information.

2 indicates the licensee did respond but provided only information on type of facillty, disposal method, and quantity of waste:

3 indicates the licensee did respond but provided only information on type of facility and disposal method.

The type of facility was classified as either Medical, Educational, Industrial, Power Reactor, or Governmental according to Part 1 of the survey form shown in Figure 5-4. It should be noted that the Medical classification includes both medical education facilties and governmental medical facilities, that the Educational classification excludes medical education facilities, and that the Governmental classification excludes both medical and educational facilities. A service 
unit, such as a laboratory, was classified according to the type of facility to which it provides the service.

of the 185 radioactive material users, contact was made with 91, of which 17 indicated they ship waste to comercial disposal facilities. Table 2-1 presents a breakdown of license holders by type of facility, response to questionnaire (telephone or written), and number of facilities using commercial disposal facilities. The "percent of all respondents" was calculated as the number of respondents shipping waste divided by the total number of respondents times 100 . The "percent of facility respondents" was calculated as the number of respondents shipping waste divided by the total number of respondents in a facility classification times 100 .

Table 2-2 presents the waste disposal practices employed, including disposal method other than shipnent to commercial disposal facilities. In this table; the total of "number using" exceeds the total number of respondents due to use of several disposal practices by some facilities. It is believed that many facilities reported only the major disposal method used rather than all methods used and the data should be viewed with this qualification in. mind. The "percent of all respondents" value was calculated as the number of respondents in a "type of facility" classification reporting use of a method divided by the total number of respondents times 100 .

Table 2-3 presents the source of the radioactivity which eventually requires use of some disposal method. 
TABLE 2-1

USE OF COMMERCIAL LOW-LEVEL WASTE PACILITIES

\begin{tabular}{|c|c|c|c|c|c|c|}
\hline \multirow[b]{2}{*}{$\begin{array}{c}\text { Type } \\
\text { of } \\
\text { facility }\end{array}$} & \multirow[b]{2}{*}{$\begin{array}{c}\text { Number } \\
\text { of } \\
\text { licensees }\end{array}$} & \multirow[b]{2}{*}{$\begin{array}{c}\text { Number } \\
\text { of } \\
\text { respondents }\end{array}$} & \multirow[b]{2}{*}{$\begin{array}{l}\text { Percent } \\
\text { response }\end{array}$} & \multicolumn{3}{|c|}{ Respondents using a commerclal facility } \\
\hline & & & & Number & $\begin{array}{c}\text { Percent } \\
\text { of all } \\
\text { respondents }\end{array}$ & $\begin{array}{l}\text { Percent } \\
\text { of facility } \\
\text { respondents }\end{array}$ \\
\hline Medical & 53 & 21 & 39.6 & 8 & 8.8 & 38.1 \\
\hline Educational & 16 & 12 & 75.0 & 5 & 5.5 & 41.7 \\
\hline Industrial & 86 & 42 & 48.8 & 1 & 1.1 & 2.4 \\
\hline Power Reactor & 1 & 1 & 100.0 & 1 & 1.1 & 100.0 \\
\hline Governmental & 28 & 15 & 53.6 & 2 & 2.2 & 13.3 \\
\hline Unknown & 1 & - & - & - & - & - \\
\hline TOTAL & 185 & 91 & 49.2 & 17 & 18.7 & - \\
\hline
\end{tabular}


TABLE 2-2

DISPOSAL PRACTICES USED FOR LOW-LEVEL RADIOACTIVE WASTES

\begin{tabular}{|c|c|c|c|c|c|c|c|c|c|c|c|c|c|c|c|}
\hline \multirow[b]{2}{*}{$\begin{array}{c}\text { Type } \\
\text { of } \\
\text { rocillty }\end{array}$} & \multirow[b]{2}{*}{$\begin{array}{c}\text { Mumber } \\
\text { of } \\
\text { reopondento }\end{array}$} & \multicolumn{2}{|c|}{$\begin{array}{l}\text { Bhlip to } \\
\text { Comanerclal } \\
\text { Repository }\end{array}$} & \multicolumn{2}{|c|}{$\begin{array}{l}\text { Releabe to } \\
\text { Sever }\end{array}$} & \multicolumn{2}{|c|}{$\begin{array}{c}\text { Combine } \begin{array}{c}\text { Hth } \\
\text { Refuse }\end{array}\end{array}$} & \multicolumn{2}{|c|}{$\begin{array}{l}\text { Vent to } \\
\text { Atomsphere }\end{array}$} & \multicolumn{2}{|c|}{$\begin{array}{l}\text { Return to } \\
\text { Vendor }\end{array}$} & \multicolumn{2}{|c|}{$\begin{array}{l}\text { Dlatribute in } \\
\text { Product Pora }\end{array}$} & \multicolumn{2}{|c|}{$\begin{array}{l}\text { No Waste } \\
\text { Generated }\end{array}$} \\
\hline & & $\begin{array}{c}\text { Nunber* } \\
\text { using }\end{array}$ & $\begin{array}{l}\text { Percent } \\
\text { of all } \\
\text { respon- } \\
\text { dents }\end{array}$ & $\begin{array}{l}\text { Number * } \\
\text { uging }\end{array}$ & $\begin{array}{c}\text { Percent } \\
\text { of all } \\
\text { respon- } \\
\text { dents }\end{array}$ & $\begin{array}{c}\text { Number* } \\
\text { using }\end{array}$ & $\begin{array}{c}\text { Percent } \\
\text { of all } \\
\text { respon- } \\
\text { dents }\end{array}$ & $\begin{array}{c}\text { Number" } \\
\text { using }\end{array}$ & $\begin{array}{c}\text { Percent } \\
\text { of all } \\
\text { respon- } \\
\text { dents }\end{array}$ & Number & $\begin{array}{l}\text { Percent } \\
\text { of all } \\
\text { respon- } \\
\text { dents }\end{array}$ & $\mid \begin{array}{c}\text { nunber * } \\
\text { us l ing }\end{array}$ & $\begin{array}{c}\text { Percent } \\
\text { of all } \\
\text { respon- } \\
\text { dents }\end{array}$ & $\begin{array}{c}\text { Number * } \\
\text { using }\end{array}$ & $\begin{array}{l}\text { Percent } \\
\text { of all } \\
\text { respon- } \\
\text { dents }\end{array}$ \\
\hline Medical & 21 & 8 & 8.8 & 3 & 3.3 & 8 & 8.8 & 1 & 1.1 & 4 & 4.4 & $\mathbf{0}$ & 0.0 & 4 & 1.4 \\
\hline Edueational & 12 & 5 & 5.5 & 3 & 3.3 & 2 & 2.2 & 1 & 1.1 & 3 & 3.3 & $\mathbf{0}$ & 0.0 & 2 & 2.2 \\
\hline Indubtelal & 42 & $\mathbf{2}$ & 1.1 & 1 & 1.1 & 0 & 0.0 & 0 & 0.0 & 23 & 25.3 & 3 & 3.3 & 15 & 16.5 \\
\hline Power Reactor & 1 & 1 & 1.1 & 0 & 0.0 & 0 & 0.0 & 0 & 0.0 & 0 & 0.0 & $\mathbf{0}$ & 0.0 & 0 & 0.0 \\
\hline Governmental & 15 & 2 & 2.2 & 1 & 1.1 & 1 & 1.1 & 0 & $0.0^{\circ}$ & 8 & .8 .8 & 0 & 0.0 & 1 & 4.1 \\
\hline TOTAL & 91 & 17 & 18.7 & 8 & 8.8 & 11 & 12.1 & 2 & 2.2 & 38 & 11.8 & 3 & 3.3 & 25 & 27.5 \\
\hline
\end{tabular}

"The total of "number using" exceeds the total number of regpondents due to use of several practices at each facllity 
TABLE 2-3

SOURCES OF RADIOACIIVITY REQUIRING DISPOSAL

\begin{tabular}{|c|c|c|c|c|c|c|c|c|c|}
\hline \multirow[b]{2}{*}{$\begin{array}{c}\text { Type } \\
\text { of } \\
\text { factlity }\end{array}$} & \multirow[b]{2}{*}{$\begin{array}{l}\text { Nunber } \\
\text { cf } \\
\text { respondents }\end{array}$} & \multicolumn{2}{|c|}{$\begin{array}{l}\text { Nuclear } \\
\text { reactor }\end{array}$} & \multicolumn{2}{|c|}{$\begin{array}{l}\text { Sealed } \\
\text { gources }\end{array}$} & \multicolumn{2}{|c|}{$\begin{array}{l}\text { Unsealed } \\
\text { radioact Ive } \\
\text { mater fal }\end{array}$} & \multicolumn{2}{|c|}{$\begin{array}{l}\text { Neutron } \\
\text { generator }\end{array}$} \\
\hline & & $\begin{array}{l}\text { Duaber } \\
\text { of } \\
\text { sources" }\end{array}$ & $\begin{array}{l}\text { Percent } \\
\text { of all } \\
\text { respon- } \\
\text { dents }\end{array}$ & $\begin{array}{l}\text { Number } \\
\text { of } \\
\text { sources* }\end{array}$ & $\begin{array}{l}\text { Percent } \\
\text { of all } \\
\text { reapon- } \\
\text { dents }\end{array}$ & $\begin{array}{c}\text { Number } \\
\text { of } \\
\text { sources" }\end{array}$ & $\begin{array}{l}\text { Percent } \\
\text { of all } \\
\text { respon- } \\
\text { dents }\end{array}$ & $\begin{array}{c}\text { Number } \\
\text { of } \\
\text { sources" }\end{array}$ & $\begin{array}{c}\text { Percent } \\
\text { of all } \\
\text { respon- } \\
\text { dents }\end{array}$ \\
\hline Medical & 17 & 0 & 0.0 & 0 & 0.0 & 17 & 25.8 & 0 & 0.0 \\
\hline Educational & 10 & 0 & $0: 0$ & 3 & 4.5 & 7 & 10.6 & 1 & 1.5 \\
\hline Industrial & 27 & 0 & 0,0 & 22 & 33.3 & 5 & 7.6 & 0 & 0.0 \\
\hline Power Reactor & 1 & 1 & 1.5 & 0 & 0.0 & 0 & 0.0 & $\mathbf{0}$ & 0.0 \\
\hline Governmental & 11 & 0 & 0.0 & 6 & 12.1 & 3 & 4.5 & $\mathbf{0}$ & 0.0 \\
\hline TOTAL. & 56 & 1 & 1.5 & 33 & 50.0 & 32 & 18.5 & 1 & 1.5 \\
\hline
\end{tabular}

"The total of "number of sources" exceeds the total number of respondents due to facllities generating waste fron severil gources 


\section{DEMOGRAPHY}

This section identifies those demographic and economic factors and trends that affect or can be related to the quantity and nature of low-level radioactive wastes within the State of Oregon, to assist with an assessment of the state as a potential producer of radioactive wastes. It also identifies those institutions, including hospitals, colleges, and universities that are major users of radionuclides that may ultimately be radioactive wastes.

\subsection{LOCATION}

Oregon is located in the nation's Pacific Northwest region. It is bounded on the north by Washington, on the east by Idaho, on the south by Nevada and California, and on the west by the Pacific Ocean. The state is physically separated from much of Washington by the Columbia River.

\subsection{POPULATION}

Population trends offer a broad-gauge measure of isotope utilization in medicine, educational and research activities, and industry. A trend revealing an increase in a state's population may imply increasing isotope use and in turn, waste generation.

Oregon ranks as the twenty-ninth most populous state in the nation and had a population density of approximately 24 persons per square mile in $1975 .(1,2)$ The state's population increased 14.0 percent between 1970 and 1977 from $2,091,533$ persons to $2,385,000$ persons. In 1978, Oregon's population totaled 2,444,000 persons, representing an annual increase of 2.5 percent. During both time periods, natural increases and migration were responsible for the population growth. Between 1970 and 1977, there were 232,591 births as compared to 141,603 deaths. This gain in population was accompanied by a net migration of 9.5 percent during this 7-year period, an inmigration of approximately 198,000 persons. In 1977, the birth rate was 15.8 births per 1,000 (approximately 37,683 births) and the death rate was 8.6 deaths per 1,000 (approximately 20,511 deaths). In 1978, the state's birth and death rates were 15.9 per 1,000 and 8.6 per 1,000 , respectively. $(3,4,5,6)$ 
(The 1978 figure represents a provisional sample of all deaths in Oregon. A final figure is currently unavailable.)

Oregon's major population centers are the Standard Metropolitan Statistical Areas (SMSA) of Eugene, Portland, and Salem, which comprised 59.4 percent of the state's population in 1978. Of the three SMSAs, Portland is the largest with a 1978 population of 968,600 persons. Between 1970 and 1977, Eugene, Portland, and Salem populations increased by $17.2,8.5$, and 17.4 percent, respectively. $(3,4)$ Figures 3-1 and 3-2 depict the location of Oregon's counties and SMSAs; Table 3-1 1ists the 1970, 1977, and 1978 population of the SMSAs; and Figure 3-3 presents the state's 1975 population density.

Population projections for Oregon forecast a total population of 2,576,900 persons by 1980. The projected population of $3,076,700$ persons in 1990 will represent a 19.4 percent increase over the 1980 population. It is estimated that between 1990 and the year 2000, the population will increase 14.8 percent and reach $3,532,600$ persons by $2000 .(8)$

\subsection{ECONOMY}

\subsubsection{Major Business Sectors}

oregon's economy has traditionally been built upon its natural resources. Lumber, agriculture/food processing, fishing, and tourism and recreation are the state's primary industries. Currently, however, the manufacturing field is growing and increasing its contribution to the state's economy. In 1978, the manufacturing sector employed 218,100 workers, a 26.6 percent increase over the 1970 manufacturing employment total of 172,300 persons.' In addition to manufacturing, retail trade, services, and state and local government are the main sector's of oregon's economy. In conjunction with the manufacturing sector, they employed a total of 741,900 workers in $1978--71.4$ percent of the total number of person's employed in oregon during that year. $(9,10,11)$ Table $3-2$ inventories the major economic activities of each county in the state. 
FIGURE 3-1

COUNTIES OF THE STATE OF OREGON (7)

$\stackrel{\varpi}{\omega}$

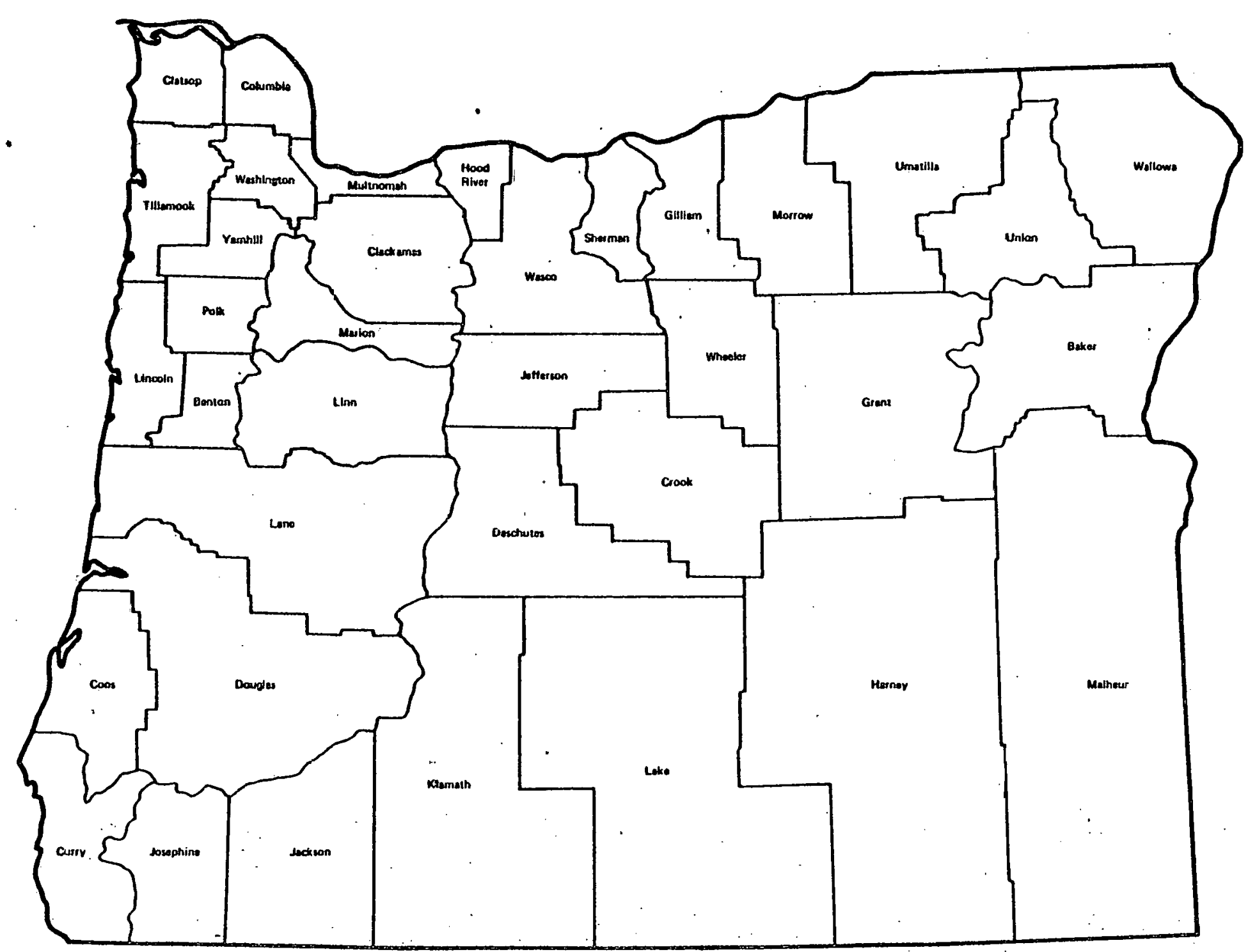


FIGURE 3-2

STANDARD METROPOLITAN STATISTICAL AREAS IN OREGON $(7)$

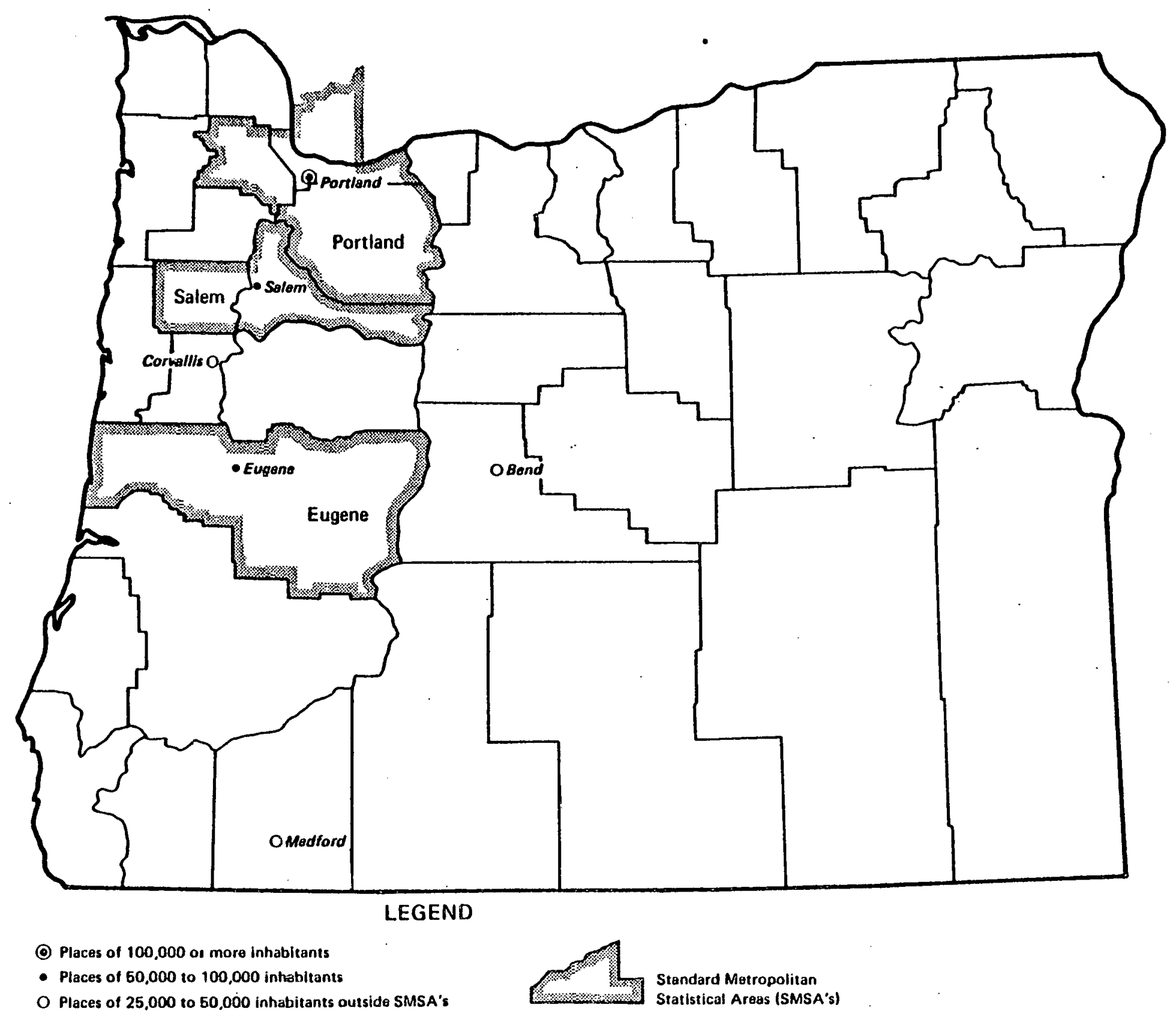


TABLE 3-1

STANDARD METROPOLITAN STATISTICAL AREAS

IN THE STATE OF OREGON $(3,4)$

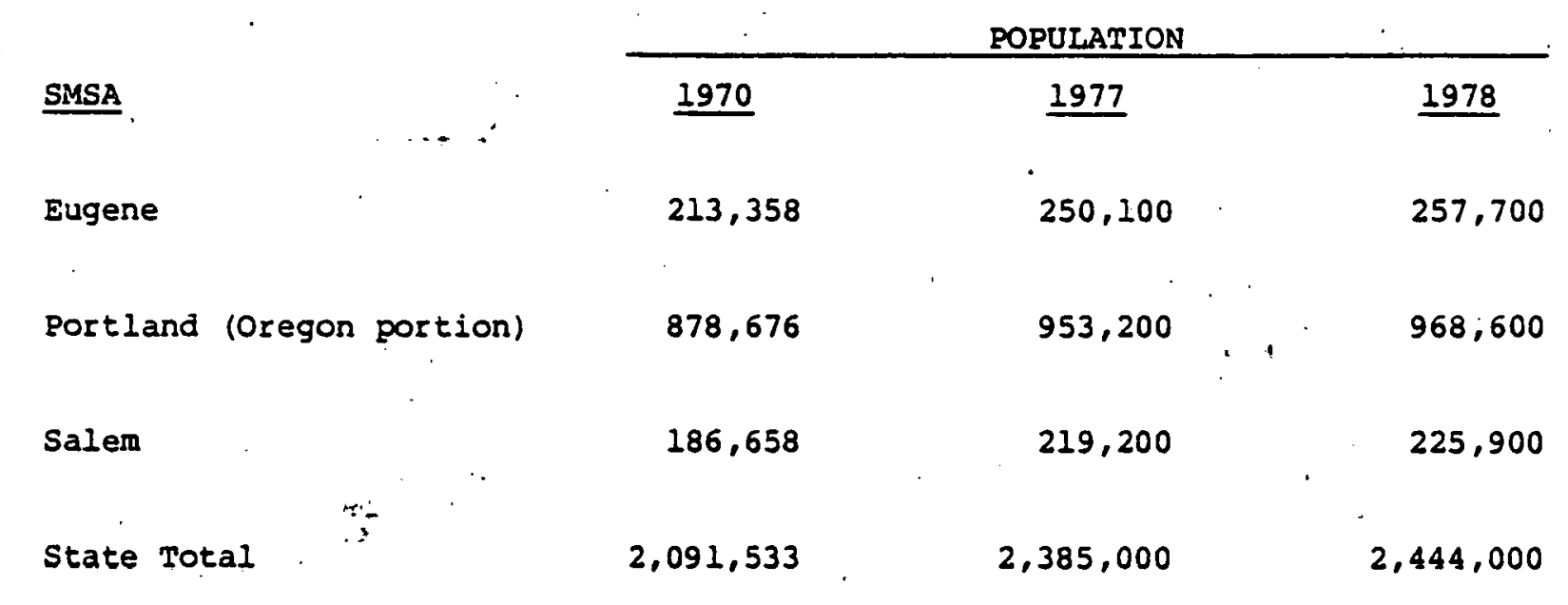


MAJOR ECONOMIC ACTIVITIES

IN ORECON BY COUNITY (8)

\section{Counties}

Linn, Jefferson, Yamhill, Lane, Douglas, Josephine, Jackson, Columbia, Rlamath

Deschutes, Crook, Wheeler

Coos, Curry, Lincoln,

Tillamock, Clatsop

Lake, Barney, Malheur, Grant, Baker

Wallowa

Hood River, Wasco, Sherman, Gillian, Morrow, Umatilla, unton

Washington, Multnomah, Clackamas

Polk, Marion

Benton
Major Economic Activities

Porestry

Forestry, Agriculture

Forestry, Fisheries

Agriculture

Tourism

Agriculture, Tour ism

Manufacturing

Government

Goverment, Oniversity, Manufacturing 


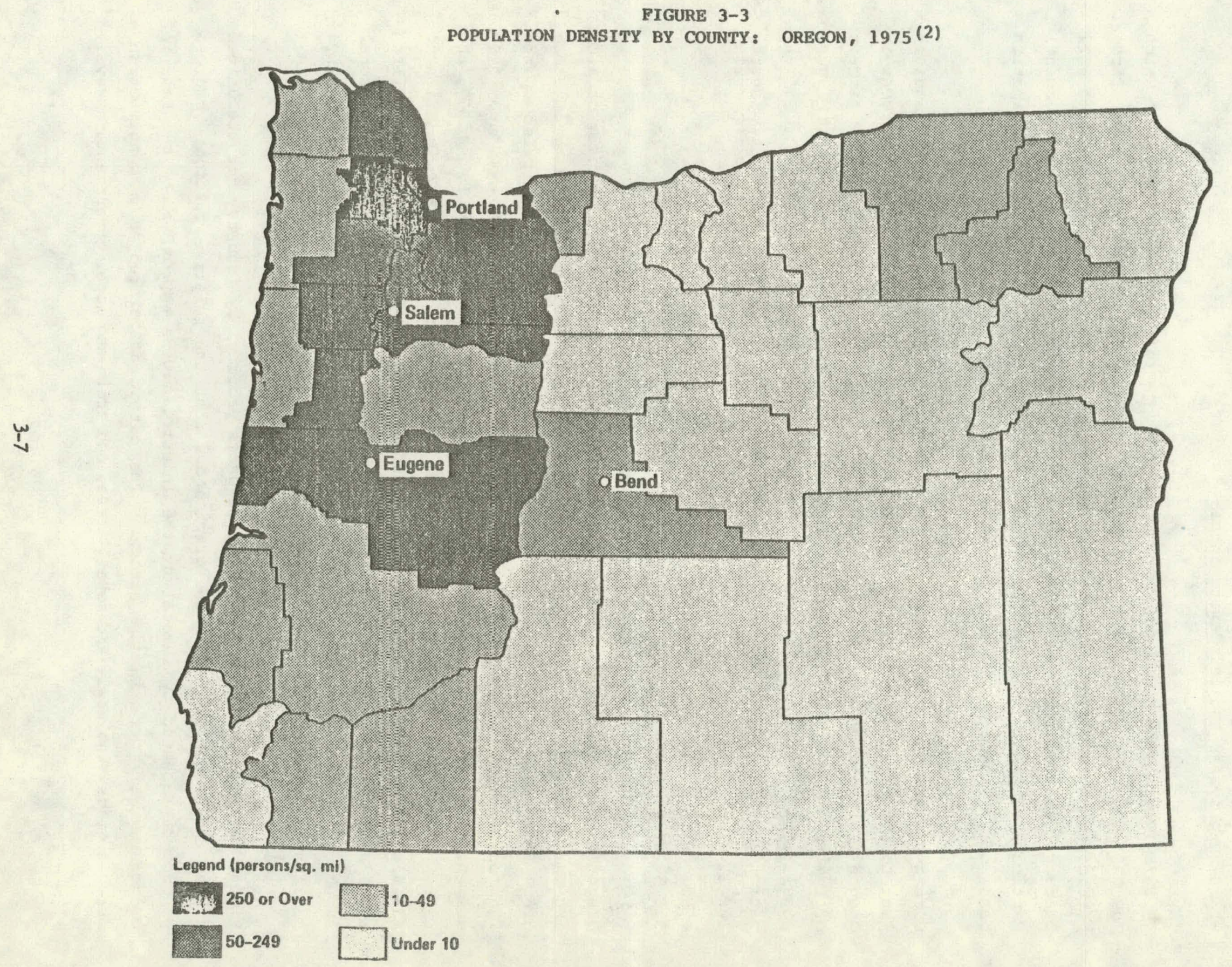




\subsubsection{Employment and Per Capita Income}

In 1978, there were 1,192,000 persons in Oregon's civilian labor force, of which 709,000 were male and 483,000 were female. This represented a total labor force participation rate of 65.7 percent, which was above the 1978 national rate of 63.2 percent. In addition, the state's male ( 79.4 percent) and female ( 52.5 percent) participation rates were above the 1978 national male and female participation rates of 77.9 percent and 50.0 percent, respectively. (

During the same year, per capita income in oregon was $\$ 7,839$, approximately equivalent to the $1978 \mathrm{U.S}$. average of $\$ 7,810$; and there were roughly 204,000 persons in Oregon living below the poverty level in 1975. This figure represented 8.9 percent of Oregon's total 1975 population compared with 11.4 percent of the 1975 U.S. population. (1) Tables 3-3, 3-4, and 3-5 present an overview of oregon's and the nation's labor force, per capita income and person's living below the poverty level.

\subsubsection{Gross State Product}

Oregon's gross state product (GSP) by industry has been estimated by first obtaining the gross national product (GNP) and U.S. employee compensation, shown in Table 3.6. The ratio of these two measures was then computed and multiplied by the figures for employee compensation for the state. Table 3-7 presents both employee compensation and the estimated Oregon GSP by industry for the years 1976, 1977, and 1978. During this period, the state's GSP rose from approximately $\$ 17.5$ million to $\$ 23.6$ million, remaining at 1.1 percent of the 1976 and 1978 GNP of $\$ 1.6$ trillion and $\$ 2.0$ trillion, respectively. $(12,13,14)$ During the same 3 -year period, personal income in oregon rose from $\$ 11.4$ million ( 1.1 percent of $0 . S$. income) to $\$ 15.4$ million (1.2 percent of U.S. income) in current dollars. (15)

Figure 3-4 represents the percentage of gross product, by industry for the United States and oregon in 1978. The graph shows that the relative portions of gross product represented by several of the industries were approximately the same in oregon as they were in the nation. The output associated with construction, durable goods, wholesale and retail trade, and state and local government, however, 
TABLE 3-3

U.S. AND OREGON LABOR FORCES (THOUSANDS), 1976, i978(1)

\begin{tabular}{|c|c|c|c|c|c|c|}
\hline & \multicolumn{3}{|c|}{1976} & \multicolumn{3}{|c|}{1978} \\
\hline & Total & Male & Female & Total & Male & Female \\
\hline U.S. & 94,773 & 56,359 & 38,414 & 100,420 & 58,542 & 41,878 \\
\hline Oregon & 1,069 & 640 & 429 & 1,192 & 709 & 483 \\
\hline Percent of U.S. & 1.13 & 1.14 & 1.12 & 1.19 & 1.21 & 1.15 \\
\hline
\end{tabular}

TABLE 3-4

PER CAPITA INCOME (CURRENT DOLIARS)

IN TRE O.S. AND OREGON FOR SELECTED YEARS(1)

$\begin{array}{ccccc}\text { Year } & \text { O.S. } & \text { Oregon } & \text { Rank } & \text { Percent of U.S. } \\ 1960 & 2,201 & 2,195 & 18 & 100 \\ 1970 & 3,893 & 3,677 & 24 & 94 \\ 1975 & 5,861 & 5,769 & 24 & 98 \\ 1978 & 7,810 & 7,839 & 19 & 100\end{array}$

TABLE 3-5

PERSONS BELOW THE POVERTY LEVEL (THOUSANDS)

IN THE U.S. AND OREGON, 1969, 1975 (1).

\begin{tabular}{|c|c|c|c|c|}
\hline \multirow[b]{2}{*}{ Year } & \multicolumn{2}{|c|}{0.5.} & \multicolumn{2}{|c|}{ Oregon } \\
\hline & Number & Percent & Number & Percent \\
\hline 1969 & 27,125 & 13.7 & 235 & 11.5 \\
\hline 1975 & 23,991 & 11.4 & 204 & 8.9 \\
\hline
\end{tabular}


TABLE 3-6

GROSS NATIONAL PRODUCT, U.S. EMPLOYEE COMPENSATION AND RATIO OF PRODUCT TO COMPENSATION (BILLIONS OF DOLLARS) BY INDUSTRY $(12,13,14)$

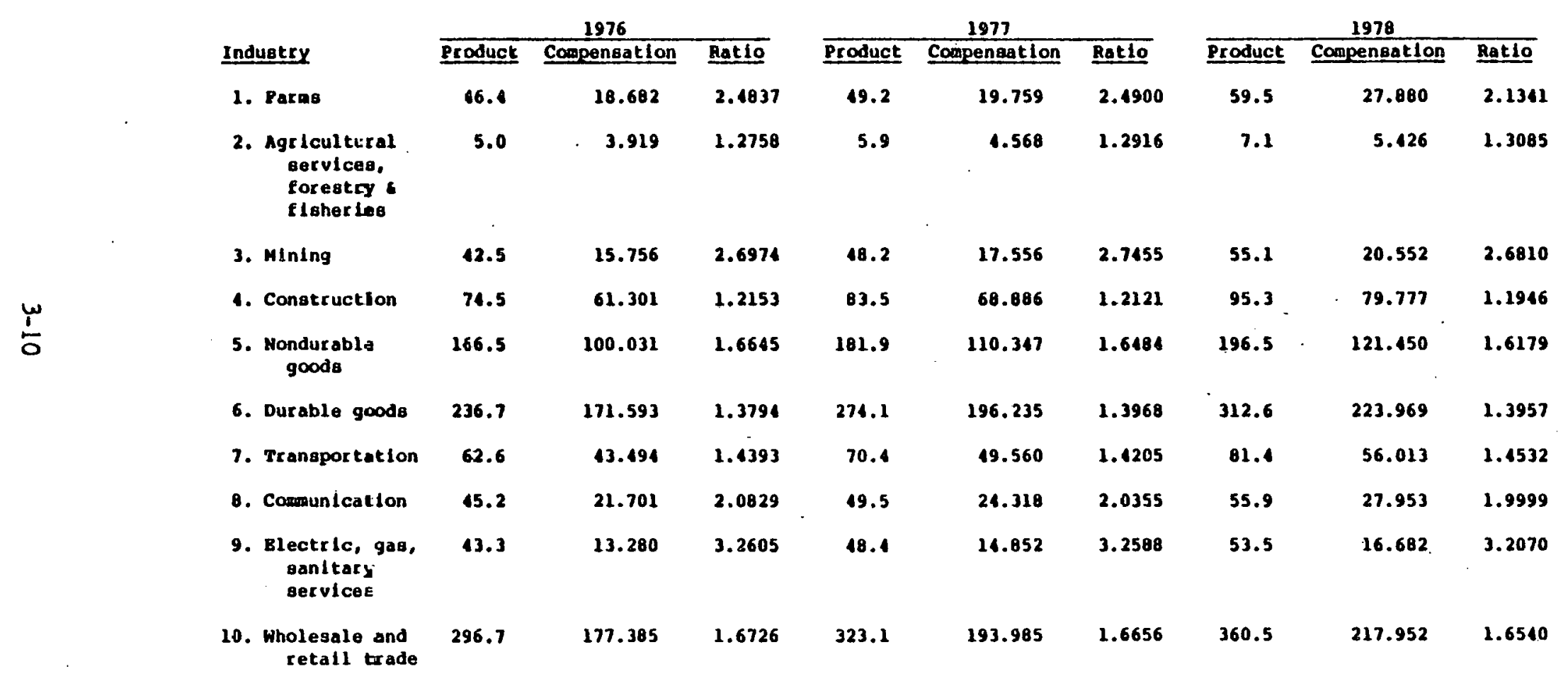


TABLE 3-6 (concluded)

GROSB NATIONAL PRODUCT, U.S. EMPLOYER COMPENSATION AND RATIO OF PRODUCT TO COMPENSATION (BILLIONB OP DOLLARS) BY INDUSTRY $(12,13,14)$

\begin{tabular}{|c|c|c|c|c|c|c|c|c|c|}
\hline Induatry & \multicolumn{3}{|c|}{1976} & \multicolumn{3}{|c|}{1977} & \multicolumn{3}{|c|}{1978} \\
\hline 11. TIRB" & 235.2 & 57.308 & 4.1041 & $267 ., 8$ & 66.548 & 4.0242 & 298.7 & 76.165 & 3.9217 \\
\hline 13. Pederal Gov. & 37.6 & 63.425 & -0.9087 & 59.0 & 67.148 & 0.8790 & 62.4 & 72.097 & 0.8656 \\
\hline $\begin{array}{l}\text { 11. Btate and } \\
\text { Local Gov. }\end{array}$ & 127.9 & 123.092 & 1.0392 & 138.1 & 133.026 & 1.0380 & 149.9 & 149.9 & 1.0380 \\
\hline TothL & 1.647 .6 & 1.044 .120 & & $1,833.9$ & $1,161.480$ & & 2.057 .1 & $1,312.219$ & \\
\hline
\end{tabular}

Tinance, Insurance, Real sotate 
TABLE 3-7

EMPLOYEE COMPENSATION AND ESTIMATED GROSS STATE PRODUCT (MILLIONS OF DOLLARS)

BY INDUSTRY FOR OREGON $(13,14)$

Industry

1. Parmen

2. Agricul tural services

3. Mining

4. Construction

5. Mondur sble goode

6. Durable goods

7. Iransportation

8. Communication

9. Blectricity, gas, san. aerv.

10. Wholesale and retall trade

11. PIRB*

i2. Servicea

13. Pederal Government

14. State ond Local Government

TOTAL.

Percent of U.8.

\begin{tabular}{|c|c|c|c|c|c|}
\hline \multicolumn{2}{|l|}{1976} & \multicolumn{2}{|c|}{1977} & \multicolumn{2}{|c|}{1978} \\
\hline compensation & GSP & compensation & GSP & Compensation & GSP \\
\hline 239.8 & 595.6 & 135.4 & 337.1 & 309.8 & 661.1 \\
\hline 71.0 & 90.6 & 94.0 & 121.4 & 121.0 & 158.3 \\
\hline 28.0 & 64.7 & 31.0 & 85.1 & 11.0 & 118.0 \\
\hline 219.0 & 873.8 & 897.0 & $1,087.3$ & $1,009.0$ & $1,300.9$ \\
\hline 684.0 & $1,138.5$ & 781.0 & $1,287.4$ & 848.0 & $1,372.0$ \\
\hline $2,174.0$ & $2,990.8$ & $2,608.0$ & 3.612 .9 & $3,101.0$ & 4.328 .1 \\
\hline 532.0 & 765.7 & 621.0 & 802.1 & 702.0 & $1,020.1$ \\
\hline 220.0 & 458.2 & 256.0 & 521.1 & 304.0 & 608.0 \\
\hline 137.0 & 0116.7 & 159.0 & 518.1 & 179.0 & 574.1 \\
\hline $2,192.0$ & $3,666.3$ & $2,508.0$ & $6,177.3$ & $2,911.0$ & $4,814.8$ \\
\hline 561.0 & $2,302.4$ & 223.0 & $2,909.5$ & 869.0 & $3,408.0$ \\
\hline $1,739.0$ & $2,082.9$ & $2,038.0$ & $2,457.8$ & $2,362.0$ & $2,859.7$ \\
\hline 160.0 & 418.0 & 508.0 & 146.5 & 567.0 & 490.8 \\
\hline $1,540.0$ & $1,600.4$ & $1,659.0$ & $1,722.0$ & $1,825.0$ & $1,894.4$ \\
\hline $11,292.8$ & 17.502 .6 & $13,018.4$ & $20,195.6$ & 15.231 .0 & $23,608.2$ \\
\hline 1.1 & 1.1 & 1.1 & 1.1 & 1.2 & 1.1 \\
\hline
\end{tabular}


represented $a^{\circ}$ slightly larger percentage of Oregon's GSP than the nation's GNP. Additionally, mining represented 2.68 percent of the nation's output and only 0.5 percent of the state's, nondurable goods represented 9.55 pecent of the U.S. output and 5.81 percent of Oregon's output, and both the state's services and federal government sectors produced outputs approximately 1.0 percent below the nation's services and federal government sectors. $(12,13,14)$

\subsection{AGRICULTURE}

The principal crops produced in oregon in 1978 were grain, forage, and miscellaneous field crops $(6,138,000$ tons); seed crops (152,000 tons); tree fruit and nuts $(296,000$ tons); berries (41,000 tons); and vegetables (852,000 tons). Of these, only the berry and tree fruit and nut totals represent a decrease in production over the 1976 production figures." The value of all crops produced in 1978 was estimated at $\$ 762,000,000$, which is 12.0 percent more than the 1977 production value and 6.0.percent more than the 1976 value. (16-22)

In addition to crop production, the state's principal livestock production in 1978 included cattle and calves $(477,225,000$ pounds); hogs $(32,970,000$ pounds); sheep and lambs $(24,442,000$ pounds); turkeys $(1,300,000$ pounds); and chickens $(2,800,000$ pounds). All livestock groups declined in production from 1976 to 1978 , but as a whole, production decreased less than 1.0 percent on an average annual basis. The value of all livestock produced was approximately $\$ 338,165,000$ in 1976 , $\$ 338,529,000$ in 1977 , and $\$ 323,768,000$ in $1978 .(16-22)$. (The 1978 figure, however, does not include the value for milk production.) Table 3-8 presents an inventory. of oregon's principal crops and the state's rank in the nation's agriculture.

\subsection{SCHOOLS AND HOSPITALS}

Several institutions in Oregon are potential sources of radioactive wastes through the use of radionuclides. Colleges and unversities are such potential sources; Oregon has 153 universities and colleges with a total enrollment of approximately 146,168 students in 1977 and 146,349 students the following year.(24,25) In 1977 , 24 institutions had enrollments of fewer than 2,500 students; 7 had student populations numbering between 2,500 and 4,999; 2 had between 5,000 and 9,999 students; . and 5 had enrollments of 10,000 or more students. (25) 
FIGURE 3-4

PERCENT OF GR.JSS PRODUCT BY INDUSTRY:

UNITED STATES AND OREGON, $1978(12,13,14)$

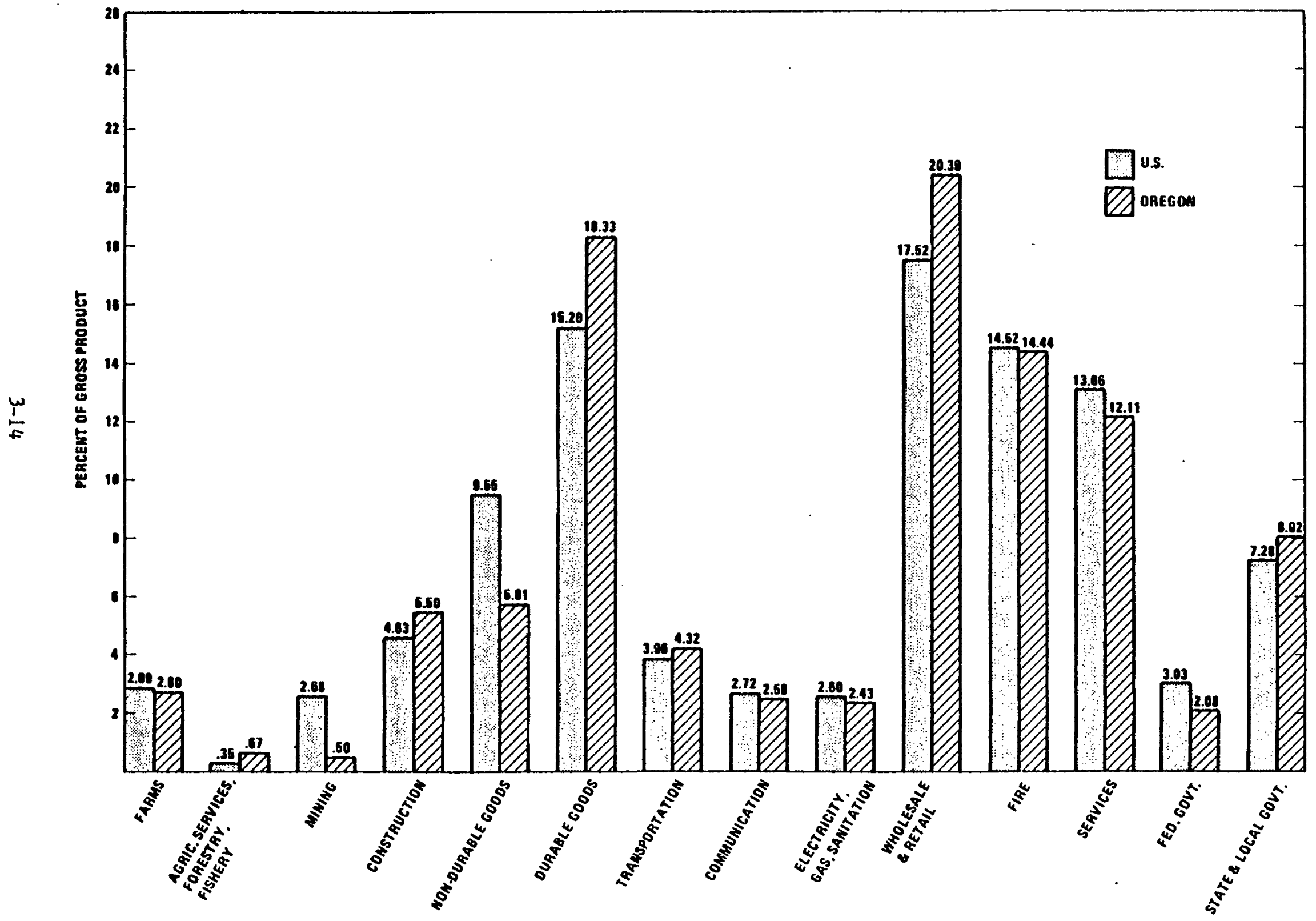


TABLE 3-8

OREGON'S RANR IN THE NATION'S AGRICULTURE, 1979(23)

\section{Commodity}

Crops:

Prunes and Plums

Snap Beans

Strawberries

Sweet Cherries

Pears

Sweet Corn

Green Peas

Potatoes

Carrots

Cranberries

Tart Cherries

Apples

Barley

Cucumbers

Peaches

Wheat (white, spring durum)

Oats

\section{Dairy Products:}

Butter

Cheese (excluding cottage cheese
Rank

Among States

2

2

2

2

3

3

4

4

5

5

6

9

11

13

15

15

18

13

19
Production as a

Percent of U.S. Totals
4.0

19.0

7.0

21.0

24.0

10.0

7.0

7.0

3.0

4.0

2.0

2.0

2.0

2.0

0.5

3.0

0.8

1.4

0.9 
In addition, Oregon had 87 hospitals with a total of 11,568 beds in 1978. Approximately 72 of these institutions had fewer than 250 beds, 10 had between 250 and 499 beds, and another 5 had 500 or more beds. ${ }^{(26)}$ In 1974, Oregon had 88 hospitals with a total of 12,088 beds, and in 1976, there were 88 hospitals in oregon with a total of 12,076 beds. The American Hospital Association explains the decrease in the number of hospitals, a national trend since 1967, as the result of the loss of specialty hospitals, predominantly from the closing of tuberculosis hospitals and the removal of hospital beds from psychiatric hospitals. $(27,28)$ 


\section{RERERENCES}

1. U.S. Department of Commerce, Bureau of the Census, Statistical Abstract of the United States, 1979, L00th edition. U.S. Government Printing Office, Washington, D.C., 1979.

2. U.S. Department of Commerce, Bureau of the Census, County and City Data Book, 1977. U.S. Government Printing office, Washington, D.C., 1977.

3. Personal communication with Thelma Ball, Bureau of the Census, Population Information Office, August 13, 1980.

4. Personal communication with Beulah Land, Bureau of Census, August 19, 1980.

5. Personal communication with Thelma Tassel, National Center for Health Statistics, Division of Vital Statistics, August 18, 1980.

6. Personal comunication with Joan Keemer, National Center for Heálth Statistics, Division of Vital Statistics, August 18, 1980.

7. U.S. Department of the Commerce, Bureau of the Census, 1970 Census of Population, Number of Inhabitants, Oregon. 'U.S. Government Printing Office, Washington, D.C., 1971.

8. Personal communication with Jerry Wood, Oregon Department of Economic Development, November 19, 1979.

9. Laila F. Cuily, Oregon: A Statistical Profile. Oregoñ Department of Economic Development, Research and Agency Liaison Division, Portland, Oregon, 1978.

10. Oregon Residential Labor Force, Onemployment and Employment, 1978. Oregon Deparment of Human Resources, mployment Division, Portland, Oregon.

11. Personal communication with Jerry wood, Oregon Department of Economic Development and Research Division, October, 11, 1979. 
12. U.S. Department of Commerce, Bureau of Economic Analysis, Survey of Current Business, Volume 59, Number 7. U.S. Government printing office, Washington, D.C., July 1979.

13. U.S. Department of Commerce, Bureau of Economic Analysis, Survey of Current Business, Volume 59, Number 8, Part II. U.S. Government Printing Office, Washington, D.C.. August 1979.

14. Personal communication with Andy Weiser, Bureau of Economir Analysis, Economic Measurements Division, June $1,1980$.

15. Personal communication with Stewart Schwartz, Bureau of Economic Analysis, Economic Measurements Division, August 5, 1980.

16. Oregon Crop and Livestock Reporting Service, "1978 Crop Production, Value and Number of Farms." Oregon Department of Agriculture, O.S. Department of Agriculture, Portland, Oregon, 1978.

17. Uregot Crop and Livestock Reporting Service, "1977 Crop Production, Value and Number of Farms." Oregon Department of Agriculture, U.S. Department of Agriculture, Portland, Oregon, 1977.

18. Oregon State Oniversity Extension Service, "Commodity Data Sheets: Chicken and Eggs." Oregon State University, Corvalles, Oregon, 1979.

19. Oregon State University Extension Service, "Commodity Data Sheets: Turkey." Oregon State University, Corvalles, Oregon, 1979.

20. Oregon State Oniversity Extension Service, "Commodity Data Sheets: Sheep, Lambs, Wool." Oregon State University, Corvalles, Oregon, 1979.

21. Oregon State University Extension Service, "Comodity Data Sheets: Bogs." Oregon State University, Corvalles, Oregon, 1979. 
22. Oregon State University Extension Service, "Commodity Data Sheets: Cattle." Oregon State University, Corvalles, Oregon, 1979.

23. Personal communication with Joe Sestak, U.S. Department of Agriculture, Economic Statistics Division September 17, 1980.

24. Personal communication with Vance Grant, U.S. Departrant of Health, Education and Welfare, Department of Education, Statistics Division, August 19, 1979.

25. Arthur Poddsky and Carolyn R. Smith, Education Directory, Colleges and Universities, 1977-1978. U.S. Department of Health, Education and Welfare, National Center for Education Statistics, Washington, D.C., 1978.

26. American Hospital Association, Guide to the Bealth Care Field. American Hospital Association, Chicago, Illinois, 1978.

27. National Center for Bealth Statistics, Office of Health Research Statistics and Technology, Public Health Service, Health Resource Statistics, 1976-1977 edition. U.S. Department of Bealth, Education and Welfare, Washington, D.C., 1977.

28. National Center for Health Statistics, Public Health Service, Hospitals: A County and Metroplitan Area Data Book, 1974. U.S. Department of Bealth, Education and Welfare, Washington, D.C., 1978. 


\section{GOVERNMENTAL AND PUBLIC ASPECTS}

This section presents an overview of Oregon's state government and identifies the government institutions and agencies with statutory or other responsibilities affecting the generation, handling, and disposal of radioactive wastes within the state. The identities and attitudes of state officials and other organizations impinging on this issue are presented in the text, and where possible, in available representative print media.

\subsection{MAJOR POLITICAL PARTIES}

The Republican Party has a larger following in Oregon than the Democratic Party has significant following in the major cities such as Portland, Eugene, and Salem, with the Republican Party having significant members in the rural areas of the state. Currently, the Democrat hold 78 percent of the 30 seats in the Oregon Senate and 57 percent of the 60 seats in the Oregon House of Representatives. Both of Oregon's United States Senators and one Congressional Representative belong to the Republican Party and the other three United. States Congressional Representatives belong to the Democratic Party. (1).

\section{2 , CONGRESSIONAL REPRESENTATIVES}

Oregon's two Congressional Senators are Mark O. Hatfield (Republican) and Bob Packwood (Republican). (1) Senator Packwood is in favor of having electrical generation capacity based on a mixture of fossil fuel and nuclear energy. As such, he does not support a moritorium on the construciton of nuclear generating facilities. In contrast, however, Senator Packwood feels that the need for additional nuclear-fuled plants. may be reduced by increases in conservation and reliance on solar energy. As the ranking minority member and the exofficio member of all subcomnittees of the Committee on Commerce, Science and Transportation, the Senator, may become involved in issues concerning the regulation of interstate carriers and highway safety. $(2,3)$

Senator Hatfield has supported legislation for a 2-year moratorium on the construction permits for nuclear electric generating facilities by the Nuclear 
Regulatory Commission. In addition, the Senator Hatfield may become involved in issues concerning nuclear waste because he is the ranking minority member of the Committee on Energy and Natural Resources. This committee is responsible for all proposed legislation, messages, and petitions concerning energy policy, energy regulation, energy research and development, and the nomilitary development of nuclear energy.

Oregon is also represented in the United States Congress by four Representatives, who are presented in Table 4-1 in conjunction with Oregon's Senators. (1) The table also indicates the congressional committees the Senators and Representative serve on and their length of service in Congress. Additionaly, the location of Oregon's congressional districts is indicated in Figure 4-1.

\subsection{STATE GOVERNMENT}

The Oregon government is divided into three branches, as required by the Oregon Constitution (adopted in 1857). The specific branches are the executive, legislative, and judicial. (1)

\subsubsection{Executive Branch}

The executive branch of government, which administers state agencies and enforces state laws, is headed by six independently elected officials. The Governor, Secretary of State, and Treasurer, in addition to their individual duties, jointly form the Land Borad. While the Governor acts as chairman of the board, the three officials have equal responsibility. The Attorney General, Superintendent of Public Instruction, and Labor Commissioner are provided by statute to carry out the special duties of their respective divisions. (1)

\section{Governor}

The present Governor, Victor G. Ateyeh (Republican), took office in January 1979. The Governor advises and recommends a budget to the State Assembly, coordinates the activities of state agencies, and serves as 
TABLE $4-1$

OREGON MEMBERS OF THE UNITED STATES CONGRESS $(3,5)$

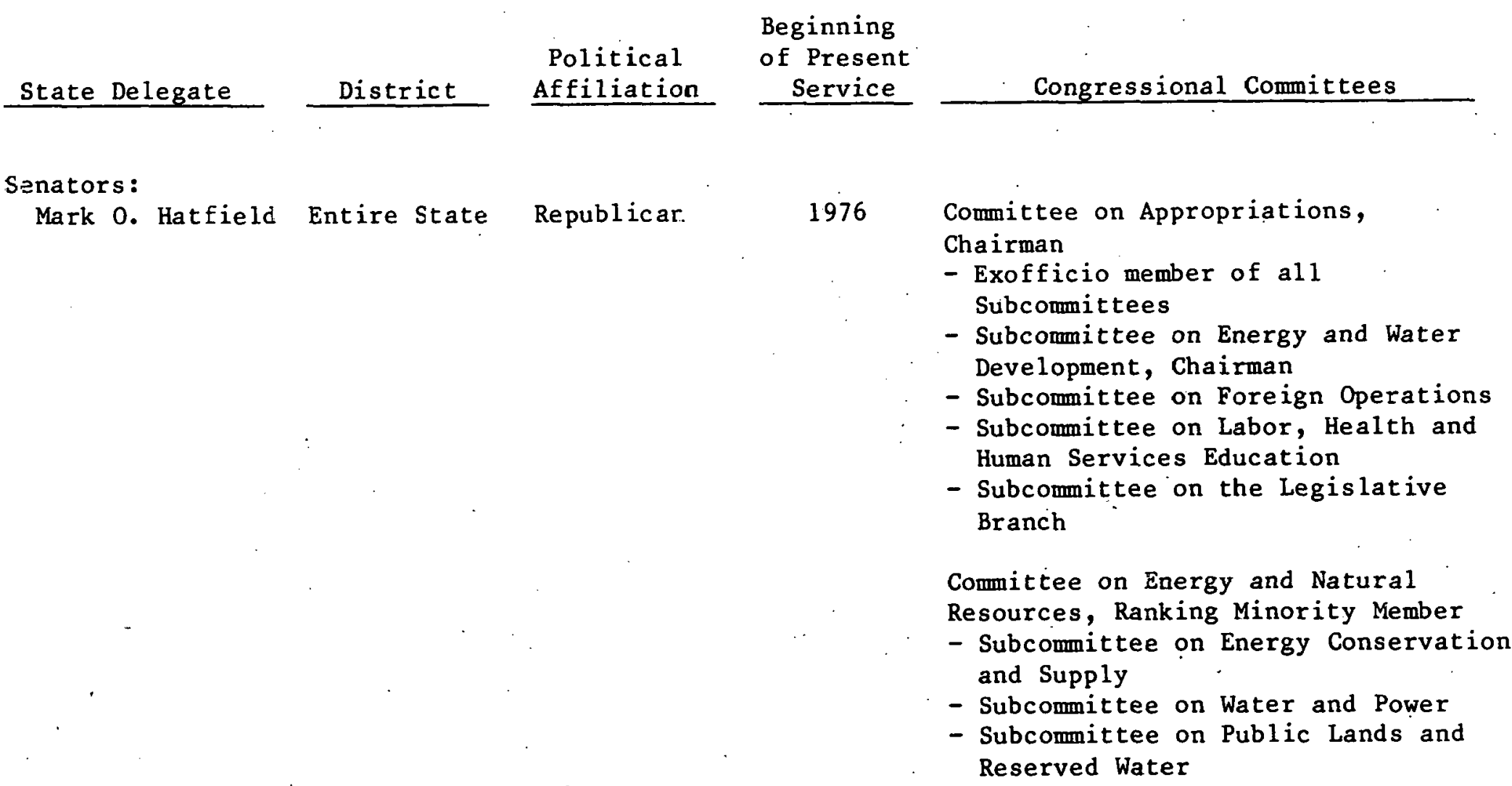

Committee on Rules and

Administration, Ranking Minority

Member

Joint Committee on Printing

Joint Committee on the Library

Committee on Commerce, Science and Transportation, Chairman

- Ex officio member of all subcomittees

- Subcomittee on Business, Trade, and Tourism 
TA3LE 4-1 (continued)

OREGON MEMBERS OF THE JNITED STATES CONGRESS $(3,5)$

State Delegate $\quad$ District $\quad \begin{gathered}\text { Beginning } \\ \text { Political }\end{gathered} \begin{gathered}\text { Begition } \\ \text { of Present } \\ \text { Service }\end{gathered}$

Bob Packwood (con't $)$

Representatives:

Les AuCo in

First

Democrat

1975

Denny Smith

Second

Republican

1981
Congressional Committees

Committee on Finance

- Subcomittee on Taxation and Debt, Chairnan

- Subcomittee on Savings, Pensions, and Investment Policy

- Subcommittee on Health Select Committee on Small Business Joint Committee on Taxation

Committee on Appropriations

- Subcommittee on the Interior

- Subcormittee on Transportation
Committee on Veteran's Affairs

- Subcomittee on Education, Training, and Employment

- Subcomittee on Compensation, Pension, and Insurance

Committee on Interior and

Insular Affairs

- Subcommittee on Insular Affairs

- Subcomittee on Energy and the Enviranment 
TABLE 4-1 (continued)

OREGON MEMBERS OF THE UNITED STATES CONGRESS $(3,5)$

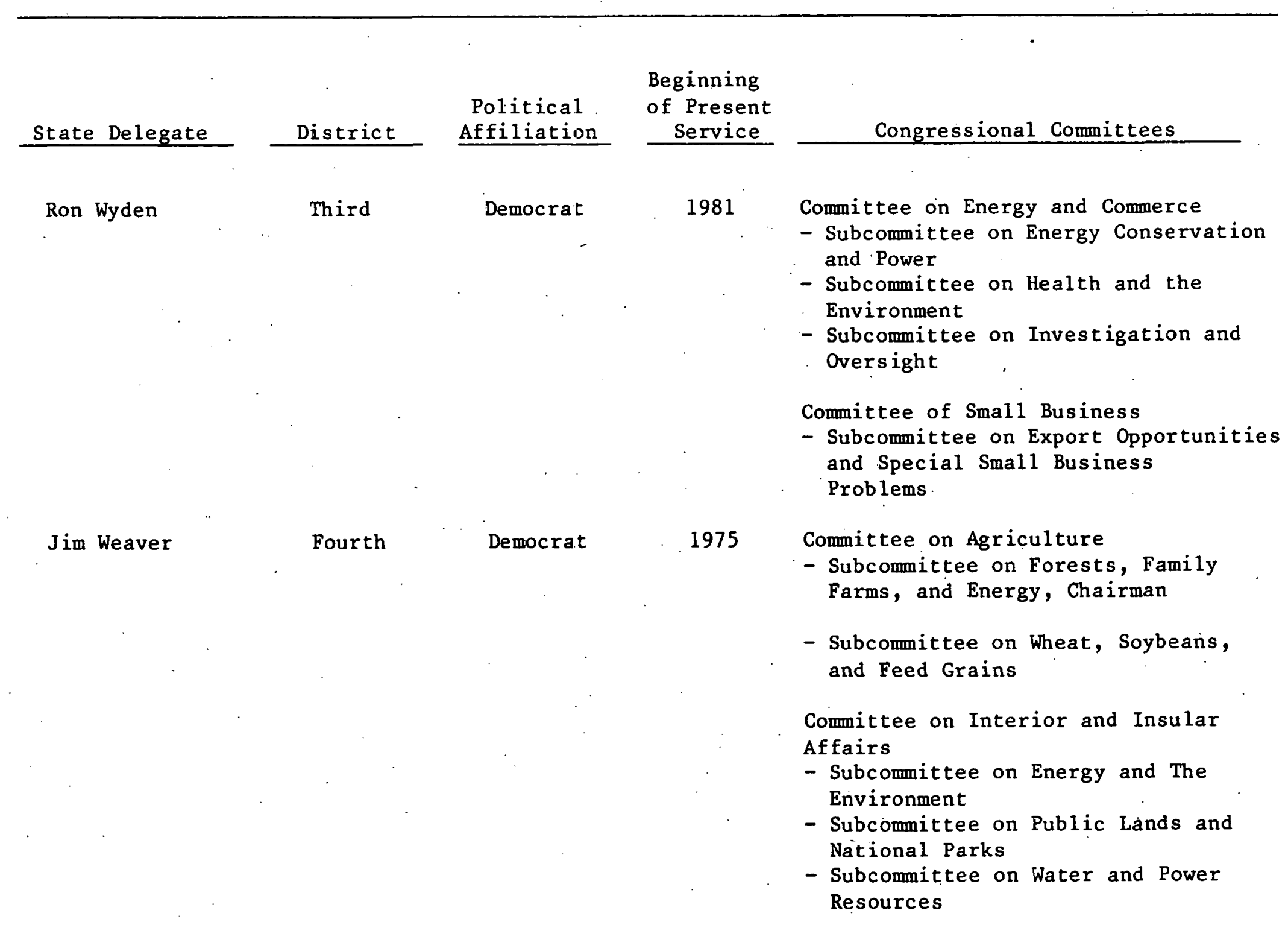


OREGON CCNGRESSIONAL DISTRICTS (1)

$\stackrel{f}{a}$

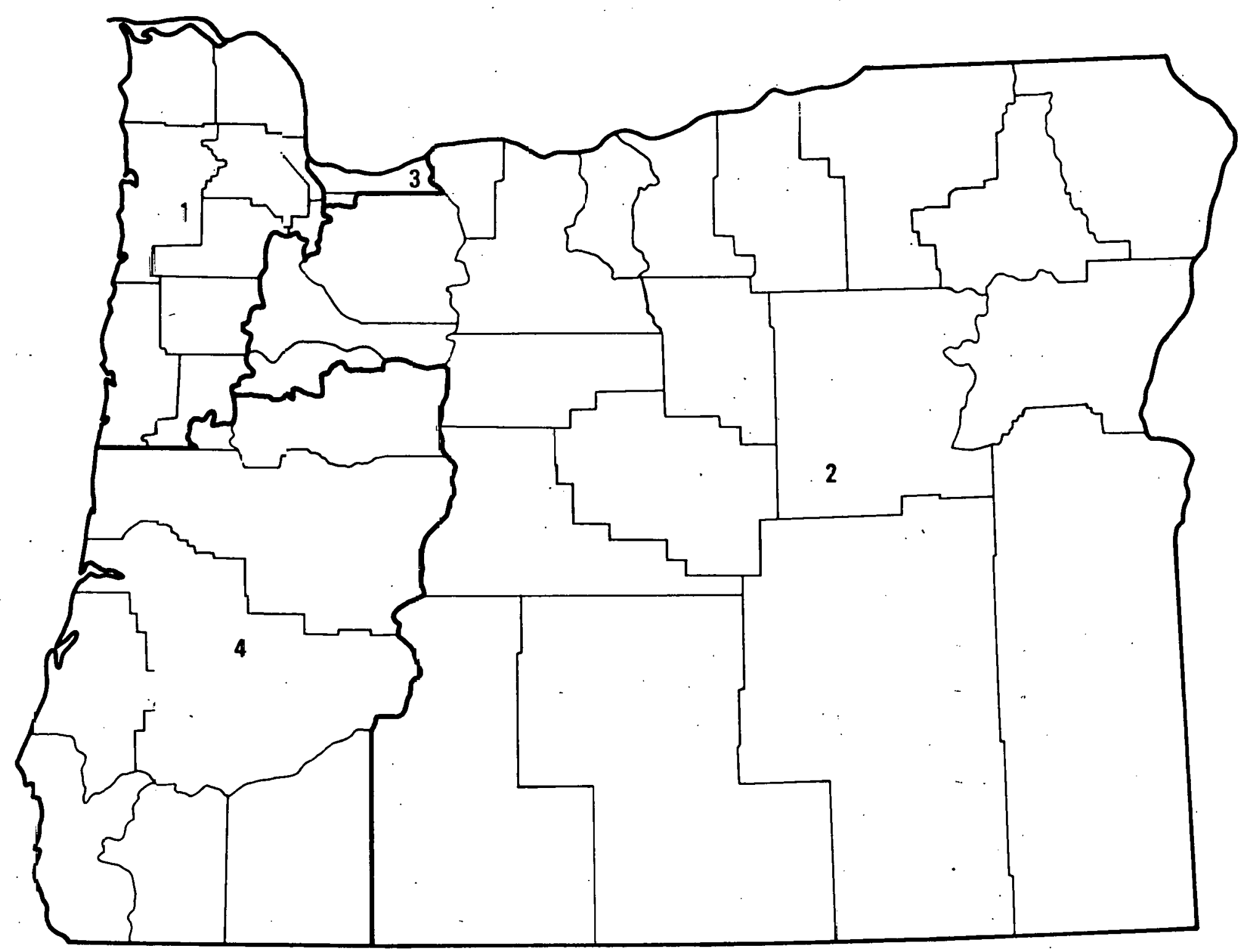


Commander-In-Chief of the state military forces. He may call special sessions of the Oregon Legislature and may veto legislation or individual items or appropriation bills. (1)

In 1979, Governor Atiyeh was aginst shutting down the Trojan nuclear generating facility; nevertheless, he delayed licensing Pebble Springs for six months because of the nuclear accident at Three Mile Island. In addition, the Three Mile Island incident prompted Governor Atiyeh to establish the Emergency Response System for the Trojan Power Plant. The system establishes open communicaton channels between the Governor and the Radiation Control Section of the Department of Human Resources, the Department of Energy, state emergency services and county emergency operations in every Oregon county and several Washington counties. In the event of an accident at the Trojan facility, only Governor Ateyeh would make the decisions, direct the emergency operations and issue press releases. Governor Atiyeh established the system to prevent confusing and conflicting directives and information during an accident and to prevent needless evacuation in the event of a false alarm. (6)

\section{Lieutenant Governor}

According to the Oregon Constitution, Oregon does not have a Lieutenant Governor. Should a vacancy occur in the office of the Governor the order of gubernatorial succession is: Secretary of State, State Treasurer, President of the Senate, and Speaker of the House. (1)

\section{Secretary of State}

The present Secretary of State is Norma Paulus (Republican), who was elected in 1976. The Secretary of State is the auditor of public accounts and chief election officer for Oregon, keeps a record of official acts of the Legislative Assembly and executive department, and is custodian of the Great Seal of the State of Oregon. As a member of the State Land Board, the Secretary of State shares responsibility with the Governor and State Treasurer for supervising the administration of state-owned lands. The secretary also sits on the Public Contact Review Board. 


\section{Attorney General}

The Attorney General of the State of Oregon is James A. Redden (Democrat), elected in 1976. The Attorney General acts as the state's legal advisor. He has full charge and control of all legal business of all state departments, boards and commissions, and state officers which require the services of legal counsel. In addition, he consults with and advises the district attorneys in Oregon's 36 counties in criminal matters, investigates criminal matters upon the request of the Governor, and handles criminal cases on appeal to Oregon's appellate courts. (1)

\section{Other Elected officials}

Other major elected state officials include Clay Myers, the State Treasurer; Verne A. Duncan, Superintendent of Public Instruction; and Mary Wendy Roberts, Labor Commissioner.

\section{State Agencies}

The Oregon Department of Human Resources, Health Division, Radiation Control Section is authorized to review the regulations and standards concerning the handling, disposal, and control of all radiation sources within oregon. They are also responsible for licensing the nuclear facilities and for monitoring the disposal and transportation of nuclear waste in the state. The Department of Energy is responsible for siting and regulating the location, construction, and operation of all nuclear installations in oregon, in addition to electric power generating facilities, pipelines, transmission lines, and solar collecting facilities. $(1,6,7)$

In addition to these agencies, other state agencies in Oregon, such as the Department of Agriculture, the Intergovernmental Relations Divison of the Executive Department or the Department of Energy, may become involved in the nuclear energy or radioactive waste disposal issue because of interest or jurisdiction in the areas of land-use planning and environmental management or protection. Figure 4-2 inventories Oregon's state agencies. 


\section{OREGON}

ADJUTANT GENERAL

Richard A. Miller, Adjutant General and Chief of Staff to the Governor

Military Department

2150 Fairgrounds Rd., N.E.

Salem OR 97303

(503) 378-3981

ADMINISTRATION

Laurence R. Sprecher, Director

Executive Department

240 Cottage St., S.E.

Salem OR 97310

(503) $378-3104$

\section{AERONAUTICS}

Paul E. Burket, Administrator

Aeronautics Division

Department of Transportation

3040 25th St., S.E.

Salem OR 97310

(503) $378-4880$

ACING

Marvin M. Janzen, Administrator

Office of Eldarly Affairs

Department of Human Resources

- 772 Commercial St., S.E.

Salem OR 97310

(503) $378-4728$

\section{AGRICULTURE}

Leonard Kunzman, Director

Department of Agriculture

Agriculture Bldg.

635 Capitol St., N.E.

Salem OR 97310

(503) $378-4152$

AIR POLLUTION CONTROL

E. Jack Weathersbee, Administrator

Air Quality Control Division

Department of. Environmental Quality

Yeon Bldg.

522 S.W. Sth Ave.

P.O. Box 1760

Portland OR 97207

(503) $229-5397$

\section{ALCOHOLISM}

Richard R. Runyon, Assistant Administrator

Programs for Alcohol and Drug Problems

Mental Health Division

Department of Human Resources

2575 Bittern St. N.E.

Salem OR 97310

(503) 378-2163
ARCHIVES AND RECORDS

James D. Porter, State Archivist

Archives Division

Office of the Secretary of State

I005 Broadway, N.E.

Salem OR 97310

(503) $378-424$

\section{ARTS AND HUMANTIES}

Peter Hero, Executive Director

Oregon Arts Commission.

835 Summer St., N.E.

Salem OR 97301

(503) $378-3625$

\section{ATTORNEY GENERAL}

James A. Redden, Attorney General

Department of Justice

100 State Office Bldg.

Salem OR 97310

(503) $378-6002$

\section{AUDIT}

George Renner, Supervisor

Audits Division

Office of the Secretary of State

$112 \mathrm{~A}$ Labor and Industries Bldg.

Capitol Mall

Salem OR 97310

(503) 378-3329

\section{BANKING}

John B. Olin, Superintendent of Banks Department of Commerce

280 Court St., N.E.

Salem OR 97310

(503) $378-4140$

BUDGET

Robert W. Smith, Administrator

Budget and Management Division Execulive Department

240 Cottage St., S.E.

Salem OR 97310

(503) 378-3103

\section{CHILD WELFAAE}

J. N. Peet, Administrator Children's Services Division Department of Human Resources 198 Commercial St.. S.E.

Salem OR 97310

(503) $378-4374$ 


\section{OREGON}

CIVIL DEFENSE

Harvey L. Latham, Administrator Emergency Services Division

Executive Department

43 State Capitol

Salem OR 97310

(503) $378-4124$

\section{Cleak OF THE hOUSE}

Winton J. Hunt, Chief Clerk

House of Representatives

H27I State Capitol

Salem OR 97310

(503) $378-8880$

\section{COMMEACE}

Cornelius C. Bateson, Director

Department of Commerce

428 Labor and Industries Bldg.

Capitol Mall

Salem OR 97310

(503) $378-4100$

\section{COMMUNITY AFFAIRS}

Donald L. Jones, Administrator Intergovernmental Relations Division

Executive Department

306 State Library Bldg.

Summer and Court Sts.

Salem OR 97310

(503) 378-5978

\section{CONFLICT OF INTEREST}

Michael K. Friel, Executive Director Oregon Government Ethics Commission 102 Public Service Bldg.

Capitol Mall

Salem OR 97310

(503) 378-5105

\section{CONSUMER AFFAIRS}

Caroline Wilkins, Administrator

Consumer Services Division

Department of Commerce

104 Labor and Industries BIdg.

Capitol Mall

Salem OR 97310

(S03) $378-4320$

\section{COARECTIUNS}

Robert J. Watson, Administrator Corrections Division

Department of Human Resources

2575 Center St., N.E.

Salem OR 97310

(503) $378-2467$

\section{COURT ADMINISTRATION}

Loren D. Hicks, State Court Administrator

Supreme Court

Supreme Court Bldg.

1147 State St.

Salem OR 97310

(503) $378-6046$ data processing

Gerald C. Schmitz, Administrator

Data Systems Division

Executive Department

625 Trade St., S.E.

Salem OR 97310

(503) 378-3161

\section{DRUG ABUSE}

Richard R. Runyon, Assistant Administrator Programs for Alcohol and Drug Problems Mental Health Division

Department of Human Resources

2575 Bittern St., N.E.

Salem OR 97310

(503) $378-2.163$

\section{ECONOMIC DEVELOPMENT}

Daniel L. Goldy, Director

Department of Economic Development

Loyalty Bldg., 9th F1.

317 S.W. Alder St.

Portland OR 97204

(503) 229-5535

\section{ECONOMIC OPPORTUNITY}

Ellen Schneider, Program Manager

State Community Services Program

Department of Human Resources

772 Commercial St., S.E.

Salem OR 97310

(503) 378-4729

\section{EDUCATION (higher)}

Roy E. Lieuallen. Chancellor Oregon State System of Higher Education

P.O. Box 3175

Eugene OR 97403

(503) 686-4153

EDUCATION (primary, socondary, and vocational)

Verne A. Duncan, Superintendent of Public

Instiuction

Department of Education

942 Lancaster Dr., N.E

Salem OR 97310

(503) $378-3573$

EMPLOYMEN'I BECUAITY

Raymond P. Thorne, Administrator Employment Division

Department of Human Resources

405 Employment BIdg.

875 Union St., N.E.

Salem OR 97311

(503) $378-321$

ENERGY

Fred Miller, Director

Department of Energy

111 Labor and Industries Bldg.

Capitol Mall

Salem OR 97310

(503) $378-4128$ 


\section{OREGON}

ENVIRONMENTAL AFFAIRS

William H. Young, Director

Department of Environmental Quality

Yeon Bldg.

522 S.W. Sth Ave.

P.O. Box 1760

Portland OR 97207

(503) $229-5696$

\section{FEDERAL-STATE RELATIONS}

Donald L. Jones, Administrator Intergovernmental Relations Division Executive Department

306 State Library Bldg.

Summer and Court Sts.

Salcm OR 97310

(503) 378-5978

\section{FINANCE}

Laurence R. Sprecher, Director

Executive Department

240 Cottage St., S.E

Salem OR 97310

(503) 378-3104

\section{FISH AND GAME}

John R. Donaldson, Director Department of Fish and Wildlife 506 S.W. Mill St.

P.O. Box 3503

Portland OR 97208

(503) 229-5551

\section{FOOD AND DRUGS}

Joe Gray, Adninistuator

Division of Food and Dairy

Department of Agriculture

Agriculture Bldg.

635 Capitol St., N.E.

Salem OR 97310

(503) $378-3790$

\section{FORESTAY}

J. E. Schroeder, State Forester Forestry Department

2600 State St.

Salem OR 97310

(503) $378-2511$

\section{general services}

Corinnc Hayen, Diroctor

Department of General Services

General Services Bjdg.

1225 Ferry St., S.E.

Salem OR 97310

(503) $378-4658$

\section{GEOLOGY}

Donald A. Hull, State Geologist

Department of Geology and Mineral Industries

1069 State Office Bldg.

1400 S.W. 5th Ave.

Portland OR 97201

(503) $229-5580$

\section{HANDICAPPED}

Fred M. Tolleson, Coordinator

Governor's Committee on Employment of the

Handicapped

Office of the Governor

208 Employment Bldg.

875 Union St., N.E.

Salem OR 97310

(503) 378-4545

\section{MEALTH}

Kristine M. Gebbie, Administrator

Health Division

Department of Human Resources

930 State Office Bldg.

1400 S.W. 5th Ave.

P.O. Box 231

Portland OR 97201

(503) 229-5032

\section{HIGHWAY SAFETY}

Gil W. Bellamy, Administrator

Traffic Safety Commission

895 Summer St., N.E.

Salem OR 97310

(503) 378-3669

\section{HIGHWAYS}

H. S. Coulter, State Highway Engineer

Highway Division

Department of Transportation

Transportation Bldg.

Capitol Mall

Salem OR 97310

(503) $378-6891$

\section{hISTORIC PAESERVATION}

David G. Tảlhot, State Parks Superintendent State Parks and Recreation Branch

Department of Transportation Vick Bldg.

525 Trade St., S.E.

Salem OR 97310

(503) 378-5019

\section{HOUSING}

M. Gregg Smith, Administrator

Housing Division

Department of Commerce

Labor and Industries Bldg.

Capitol Mall

Salem OR 97310

(503) $378-4343$

\section{HUMAN RIGHTS}

Malcolm H. Cross, Administrator

Civil Rights Division

Bureau of Labor

State Office Bldg.

1400 S.W. 5th Ave.

Portland OR 97201

(503) $229-6076$ 


\section{INSURANCE}

W. W. Fritz, Insurance Commissioner

Insurance Division

Department of Commerce

Commerce Bldg.

158 12th St., N.E.

Salem OR 97310

(503) $378-4474$

\section{JUVENILE DELINQUENCY}

Richard S. Peterson, General Superintendent

Juvenile Corrections Services

Children's Services Division

Department of Human Resources

2450 Strong Rd., S.E.

Salem OR 97310

(503) $378-5341$

\section{LABOR}

Bill Stevensö̆, Cómmissioner

Bureau of Labor

State Office Bldg.

1400 S.W. Sth Ave.

Portland OR 97201

(503) 229-5735

\section{LAW ENFORCEMENT PLANNING}

Keith A. Stubblefield, Administrator

Law Enforcement Council

Slate Planning Agency

2001 Front St., N.E

Salem OR 97310

(503) 3784347

\section{LEgislative hesearch}

Thomas G. Clifford, Legislative Counsel

Legislative Counsel Commiltec

SIOI State Cupitul

Salem OR 97310

(503) $378-8148$

\section{LIBRARY SERVICES}

Marcla Lowéll, State Lubrarian

State Library

State Library Bidg.

Summer and Court Sts.

Salem OR 97310

(503) $378-4243$

LICENSING (occupational and professlonal)

Cornelius C. Bateson, Director

Department of Commerce

428 Labor and Industries Bldg.

Capitol Mall

Salem OR 97310

(503) $378-4100$

\section{LIQUOR CONTROL}

C. Dean Smith, Administrator Oregon Liquor Control Commission

9079 S.E. McLoughlin Blvd.

P.O. Bnx 22297

Portland OR 97222

(503) 653-3018

\section{MASS TRANSIT}

Dennis H. Moore, Administrator

Public Transit Division

Department of Transportation

304 Transportation Bldg.

Capitol Mall

Salem OR 97310

(503) $378-8200$

MENTAL HEALTH

J. D. Bray, Administrator

Mental Health Division

Department of Human Resources

2575 Bittern St., N.E.

Salem OR 97310

(503) 378-2671

\section{MENTAL RETARDatIon}

David A. Isom. Assistant Administrator Mental Heallh Division

Department of Human Resources

2575 Bittern St., N.E.

Salem OR 97310

(503) $378-2429$

\section{MINING}

Donald A. Hull, State Geologist

Department of Geology and Mineral Industries 1069 State Office Bldg.

1400 S.W. 5th Ave.

Portland OR 97201

(503) $229-5580$

MOTOR VEHICLES

Harold L. Grover, Administrator

Motor Vehicles, Division

Department of Transpoitation

1905 Lana Ave., N F.

Salem OR 97314

(503) 378-6997

NATURAL RESOURCES

Janet MoLennan; Administrative Assistaul lo the Governor for Natural Resources

Office of the Governor

160 State Capitol

Salem OR 97310

(503) 378-3109

MUCLEAR CNERQY

Fred Miller, Director

Department of Energy

111 Labor and Industries Bldg.

Capitol Mall

Salem OR 97310

(503) $378-4128$

\section{OCCUPATIONAL SAFETY AND HEALTH}

Darrel Douglas, Administrator

Accident Prevention Division

Workers' Compensation Department

204 Labor and Industries Bldg.

Capitol Mall

Salem OR 97310

(503) $378-3272$ 


\section{OREGON}

\section{OIL AND CAS}

Donald A. Hull, State Geologist

Department of Geology and Mineral Industries 1069 State Office Bldg.

1400 S.W. 5th Ave.

Portland OR 97201

(503) 229.5580

\section{OMBUDSMAN}

Phil McLaurin, Ombudsman

Office of the Governor

160 State Capitol

Salem OR 97310

(503) $378-4582$ or $1-800-452-7813$

\section{PARKS}

David G. Talbot, State Parks Superintendent

State Parks and Recreation Branch

Department of Transportation

Vick Bldg.

525 Trade St., S.E.

Salem OR 97310

(503) $378-5019$

\section{PEASONNEL}

Richard J. Burke, Administrator

Personnel Division

Executive Department

100 Public Service Bldg.

Capitol Mall

Salem OR 97310

(503) $378-3140$

\section{PLANNING}

Donald L. Innes, Administrator

Intergovernmental Relations Division

Executive Department

306 State Library Bldy.

Summer and Court Sts.

Salem OR 97310

(503) $378-5978$

\section{POLICE}

Robert R. Fisher, Superintendent

Department of State Police

107 Public Service Bldg.

Capitol Mal

Salem OR 97310

(503) $378-3720$

\section{painting and pUblishing}

John R. Chamberlain, State Printer

Printing Division

Department of General Services

General Services Bldg.

1225 Ferry St., S.E.

Salem OR 97310

(503) 378-3564

\section{PROBATION AND PAROLE}

Nancy Peck Farrar, Executive Director Buard of Parole

2575 Center St., N.E.

Salem OR 97310

(503) 378-2334
PUBLIC DEFENDER

Gary D. Babcock, Public Defender.

Office of the Public Defender

Mill Creek Office Park

555 13th St., N.E.

Salem OR 97310

(503) $378-3349$

PUBLIC UTILITIES

Charles Davis, Commissioner

Puhlic Utility Commissioner

Labor and Industries Bldg.

Capitol Mall

Salem OR 97310

(503) $378-6611$

\section{PURCHASING}

Lee E. Moore, Administrator

Purchasing Division

Department of General Services

General Services Bldg.

1225 Ferry St., S.E.

Salem OR 97310

(503) $378-4643$

RAILROADS

David Astle, Assistant Commissioner Rail-Air-Marine Program

Public Utility Commissioner Labor and Industries Bldg.

Capitol Mall

Salem OR 97310

(503) $378-6351$

\section{RETIREMENT}

James L. McGoffin, Director Public Employees Retirement Board 200 Terminal $\mathrm{Plz}$

1221 S.W. Yambill St.

Portland OR 97205

(503) 229-6028

\section{BECAETARY OF STATE}

Norma Paulus, Secretary of State Office of the Secretary of State

136 State Capitol

Salem OR 97310

(503) $378-4139$

\section{SECRETARY OF THE SENATE}

Maribel Cadmus, Secretary of the Senate State Capitol

Salem OR 97310

(503) 378.8168

\section{SECUAITIES}

Andrew Ositis, Assistant Commissioner

Securities Section

Corporation Division

Department of Commerce

Commerce Bidg.

158 12th St. N.E.

Salem OR 97310

(503) $378-4387$ 


\section{OREGON}

BOCIAL BEAVICES

Richard A. Davis, Director

Department of Human Resources

318 Public Service Bldg.

Capitol Mall

Salem OR 97310

(503) 378-3034

\section{SOLID WASTE MANACEMENT}

Ernest A. Schmidh Administrator

Solid Waste Division

Department of Environmental Quality

Yeon Bldg.

522 S.W. Sth Ave.

P.O. Box 1760

Portland OR 97207

(503) 229-5356

8TATE-LOCAL RELATIONS

Donald L. Jones, Administrator

Intergovernmental Relations Division

Executive Department

306 State Library Bldg.

Summer and Court Sts.

Salem OR 97310

(503) $378-5978$

TAXATION AND REVENUE

John J. Lobdell, Director

Department of Revenue

204 State Office Bldg.

Salem OR 97310

(503) $378-3363$

\section{TOURISM}

Victor B. Fryer, Manager

Travel Information Section

Department of Transportation

Transportatiun Bldg.

Capitol Mal!

Salem OR 97310

(503) 378-6309

\section{TRANSPOATATION}

Robert A. Burco, Director of Transportation Department of Transportation

135 Transportation Bldg.

Capitol Mall

Salem OR 97310

(503) $378-6388$

\section{TREASURER}

Clay Myers, State Treasurer

Treasury Department

157 Stale Capitol

Salem OR 97310

(503) $378-4329$
VETERANS: AFFARS

H. C. Saalfeld, Director

Department of Veterans' Affairs

200 Generd Services Bldg.

1225 Ferry St., S.E.

Salem OR 97310

(503) $378-6850$

VTAL AECORDS/8TATISTICS

Marian M. Martin, State Registrar

Vital Statistics Section

Health Division

Department of Human Resources

965 State Office Bldg.

1400 S.W. 5th Ave.

P.O. Box 116 (97207)

Portland OR 97201

(503) 229-5898

WATER POLLUTION CONTROL

Harold L. Sawyer, Administrator

Water Quality Control Division

Department of Environmental Quality

Yeon Bldg.

522 S.W. Sth Ave.

P.O. Box 1760

Portland OR 97207

(503) 229-5324

WATER RESOURCES

James E. Sexson, Director

Water Resources nepartment

Mill Creek Office Park

555 13th St., N.E.

Salem OR 97310

(503) $378-2982$

WELFARE

Keith Putman, Administrator

Adult and Family Services Division

Department of Human Resources

417 Public Service Bldg.

Capitol Mall

Salem OR 97310

(503) $378-3680$

\section{WORKMEN'S COMPENSATION}

Roy G. Green, Director

Workers' Compensation Department

20M Labor and Industries Bldy.

Capitol Mall

Salem OR 97310

(503) $378-3304$ 


\subsubsection{Legislative Branch}

Oregon's legislative power is vested in the Oregon Legislative Assembly, which is composed of the Oregon Senate and the House of Representatives. The state is divided into 30 legislative districts according to a 1952 reapportionment. Each district elects one senator and two representatives. As such the senate consists of 30 members and the house consists of 60 members. The senators and the representatives are each elected every 2 years. (1) Figures $4-3$ and 4-4 delineate the state legislative districts.

The Legislative Assembly convenes the second Monday in January each odd numbered year. The oregon Constitution does not limit the length of sessions, but recent sessions have lasted approximately 6 months. Special sessions of the legislature may be called by the Governor or by a majority of each house. (1)

The primary functions of the legislature are to enact laws, and finance state government. The Legislative Assembly also confirms various gubernatorial appointments and reviews the administrative rules of certain agencies. Most of the work in either house in the assembly is done in committee. The committees hear testimony on a measure, then amend the measure if necessary and return it to the house of origin for debate. The committee also has the authority to kill a measure, ending its consideration. (1)

In 1979, the Legislative Assembly introduced legislation dealing with nuclear power and low-level radioactive waste--House Bill 2570, sponsored by Representative Rick Bauman and 19 other legislative members. The bill calls for the Department of Energy to conduct a study of Three Mile Island, including the quantity of radioactive waste generated and its long-term storage. Additionally, the bill declares that the findings should be made a part of the site certificate proceedings of the Energy Facility Siting Council. Senate Bill 394, introduced by Senator Ted Hallock, was passed by the Legislature and approved by Governor Atiyeh in 1979. This law governs the transportation and disposal of radioactive-waste produced in the state, and prohibits the establishment, operation, and licensing of radioactive waste disposal facilities in the state of oregon. (7) This bill is presented in Appendix B. 
FIGURE 4-4

OREGON REPRESENTATIVE DISTRICTS (1)

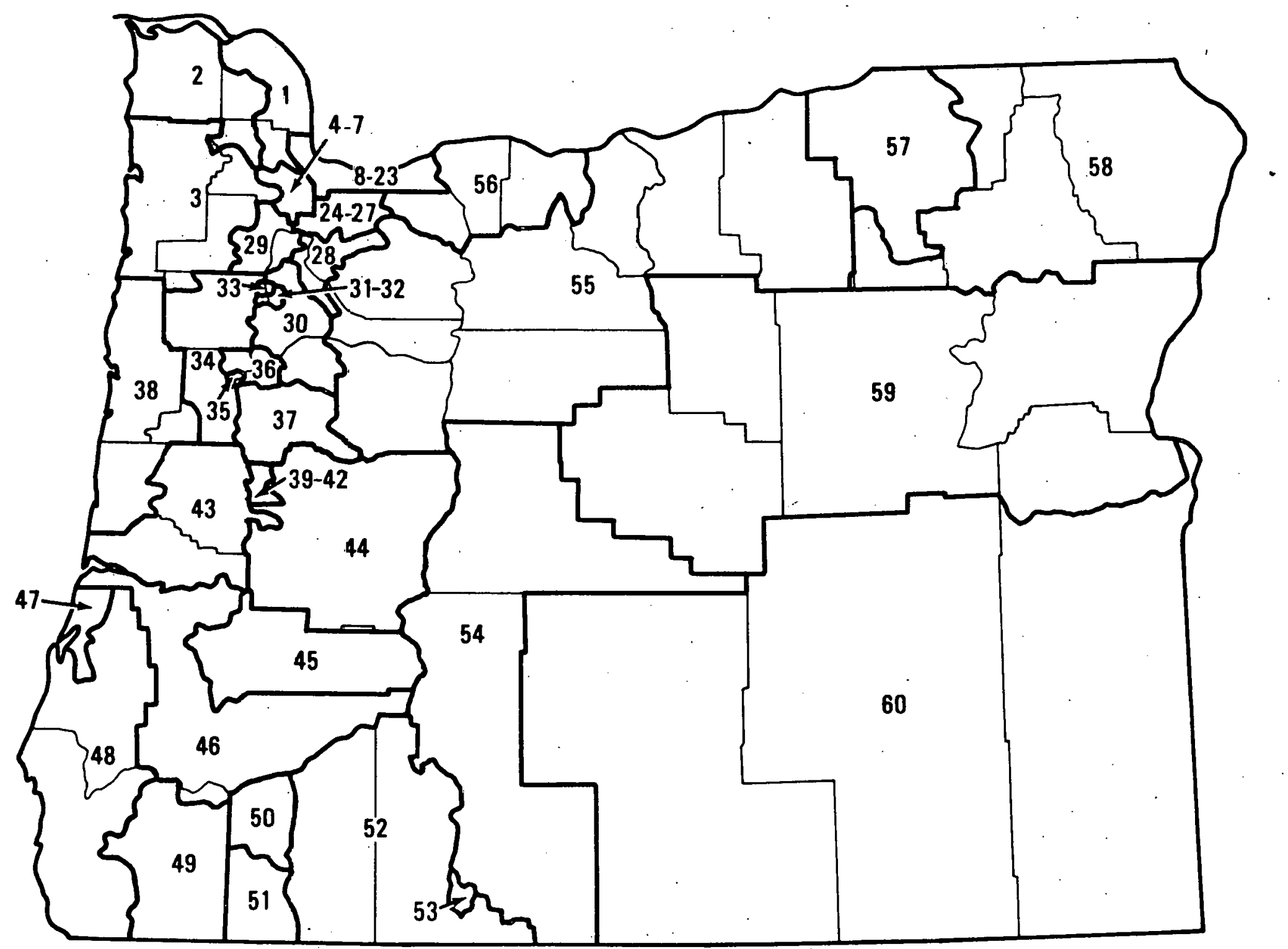




\subsubsection{Judicial Branch}

The judicial branch consists of one supreme court, one court of appeals, one tax court, circuit courts, and district courts. Seven justices comprise the supreme Court of Oregon and this court has general administrative authority over all other courts in the state. The supreme court justices are elected by nonpartisan statewide ballot for a 6-year term. (1)

The Court of Appeals of Oregon is comprised of 10 judges, serving 6-year terms. The court has exclusive jurisdiction over all appeals; both civil and criminal, from the circuit and district courts. Additionally, the court of appeals is responsible for the review of state administrative agency orders, Corrections Division disciplinary actions and Board of Parole orders.

The Oregon Tax Court has exclusive authority over tax questions relating to income, inheritance, gift, real property, personal property, timber and cigarette taxation, and local budget levy. Court is usually held in the county where the taxpayer resides or where the property is located. The judge serves a 6-year term and is elected on a state-wide, nonpartisan judicial ballot. (1)

The circuit courts are the state trial courts of general jurisdiction. There are 75 circuit judges serving the 36 oregon counties, which are grouped in 20 geographical areas called judicial districts. Circuit court judges are elected for a term of 6 years. (1)

The district courts are trial courts with jurisdiction limited to $\$ 3,000$ in civil cases and to some misdemeanor criminal cases, including traffic offenses. District courts may also conduct preliminary hearings on felony matters and each has a small claims department which handles disputes concerning the recovery of money or damages up Lo $\$ 500$. The district court's geographical jurisdiction is by county. There are 51 district judges sitting in 24 of Oregon's 36 counties and judges are elected on a nonpartisan ballot in the individual county. District court judges may be assigned by the supreme court to serve other district courts or to serve temporarily as circuit judges. 


\subsubsection{Statutory Regulations}

The State of Oregon has a specific regulation concerning radioactive waste storage and one concerning the transportation of radioactive material. $(9,10)$ These regulations, part of the Energy Facility siting Council's Rules on radioactive waste materials, restrict the temporary storage of radioactive material and outline the procedure for transporting radioactive material in oregon. In addition; Oregon statute 469.525, as amended by House Bill 394, states that "no waste disposal facility for any radioactive material shall be established, operated or licensed within the state of Oregon." (11) Both House Bill 394 and Oregon's regulations on radioactive materials are presented in Appendix B.

\subsection{FEDERAL ACTIVITIES IN THE STATE OF OREGON}

Currently, there is no ongoing, proposed, or pilot federal project or program within the state with respect to radioactive waste disposal. (7)

\subsection{INTEREST GROUPS}

Many interest groups concerned with nuclear issues and radioactive waste have offices in oregon. In addition, there are many groups generally concerned with the environment who may become actively involved in nuclear energy and waste management issues if they view the issues as detrimental to their environmental interests. Following is a list of some of the major energy and environmental organizations located in oregon and their specific areas of concern. $(12,13,14)$

American Society of Civil Engineers, Pacific Northwest Council: Professional group concerned with the nuclear energy field.

Clatstop County Environmental Council: Founded to preserve and protect the environment of Clatstop County.

Conservation of Urban and Rural Environment (CURE): Concerned with preserving the viable environment of Central Oregon; actively lobbies the Oregon Legislature on bills affecting the environment. 
Eugene Future Power Committee, Inc.: Originally formed to fight local public utilities' plans to construct a nuclear power plant. The Committee monitors local, state, and national nuclear developments and studies alternative power sources and energy conservation options.

Friends of the Earth, Portland Group: Committed to the "preservation, restoration and rational use of the earth." Some of their interests concern the issues of nuclear power safety, strip mining, energy conservation, and water pollution.

Oregon Association of Conservation Districts: Concerned with wise land-use planning and involved in legislative action concerning environmental issues.

Oregon Environmental Council: Concerned with general environmental issues and is involved in public education and legislation concerning these issues.

Oregon Environmental Foundation: The foundation is the educational and research arm of the Oregon Environmental Council.

Oregon Environmental Health Association: A group of professionals interested in radiological health, air and water pollution control, solid-waste management,. community planning, and industrial hygiene.

Sierra Club, Pacific Northwest Chapter: The Sierra Club'E Fnergy Committee advocates a moratorium on the further construction of nuclear plants. In general, the club is concerned with the natural environment and protecting it from the adverse impacts of man and his society.

Trofan Decommissioning Alliance: Concerned with nuclear power safety and actively opposes the existence of the Trojan nuclear facility.

\subsection{PRINTED MEDIA}

The 21 articles presented in Appendix C represent a 2-week search of 2 major newspapers in the state and are related to the broad subject of nuclear power. Although the issues reviewed did not produce' more than two articles specifically related to low-level radioactive waste, the articles are intended to present a 
general indication of the coverage of radiation issues by printed media in the State of Oregon.

In addition to the articles in Appendix $C$, the oregon Journal has printed approximately 24 editorials on nuclear wastes and nuclear energy, which may further indicate the media's coverage of these issues in the state. (15) During the same time the Oregon Statesman printed one editorial on the topic of nuclear energy. Neither newspaper however, has recently conducted any polls or surveys concerning nuclear energy or radioactive waste issues. $(16,17)$ 


\section{REFERENCES}

1. Oregon Blue Book, 1979-1980. Office of Secretary of the state, state of Oregon, Salem, Oregon, 1979.

2. Personal communication with Bruce Hagman, member of Senator Bob Packwood's staff, November $30,1979$.

3. Charles B. Brownson, 1980 Congressional Staff Directory. Mt. Vernon, Virginia, 1980.

4. Personal communication with Jeff Booth, Member of Senator Mark Hatfield's staff, November 11, 1979.

5. 1979 Congressional Directory, 96th Congress, lst Session. U.S. Government Printing Office, Washington, D.C., 1979.

6. Personal communication with Dr. Perrit, Oregon Department of Human Resources, Radiation Control Section, August 19, 1980.

7. Personal communication with David Wagstaff, Oregon Department of Human Resources, Radiation Control Section, August 12, 1980.

8. The National Directory of State Agencies, 1978-1979. Information Resource Press, Washington, D.C., 1978.

9. Oregon Administrative Rules, Energy Facility Siting Council, Chapter 345, Division 50, Radioactive Waste Materials, Rule 345-50-006 through 345-50-035.

10. Oregon Administrative Rules, Energy Facility Siting Council, Chapter 345, Division 60, Transportation of Radioactive Material, Rule 345-60-001 through 345-60-007.

11. Enrolled Senate Bill 394, Oregon Legislative Assembly, 1979. 
12. Thaddeus C. Tryna and Sally R. Osberg, Environmental Protection Directory. Marques Academic Press, Chicago, Illinois, 1975.

13. Onyx Group, Inc., Environment U.S.A., A Guide to Agencies, People, and Resources. R.P. Bowker Co., New York, N.Y., 1974.

14. Center for California Public Affairs, Directory of Consumer Protection and Environmental Agencies. Academic Press, Orange, New Jersey, 1973.

15. Personal communication with Sue Montgomery, The Oregon Journal, August 26, 1980 .

16. Personal communication with Martha Vargine, Oregon Statesman, August 24, 1980 .

17. Personal comunication with Barbara Hitton, Oregon State Library, September 2, 1980 . 


\section{SURVEY METHODOLOGY}

A direct mail survey was conducted during September 1979 of all Radioactive Material License holders in the state of Oregon. Names of license holders were obtained from the Oregon Department of Buman Resources. The questionnaire used is presented in Figure 5-1. This "free form" questionnaire was developed to solicit basic information necessary to generally characterize the low-level radioactive waste management practices. Questions asked were'limited to those which have a direct bearing on the overall characterization of practices within the state, rather than on a detailed characterization of each facility.

Each questionnaire was sent with a transmittal letter (see Figure 5-2), general instructions (see Figure 5-3), and a return envelope. Responses were first evaluated to determine the information presented in Appendix A, List of Radioactive Material ticensees. If a response was not received, classification of "type of facility" was determined from the licensee name, if possible; if not, they were classified as "unknown." The responses received were then transposed onto a "fixed form" survey form (see Figure 5-4) which was developed based on analysis of the "free form" responses given in Figure 5-1. The information provided by the licensees was then tabulated in the formats presented in Sections 2 and 6 of this briefing book. 
FIGURE 5-1

NUS RADIOACTIVE WASTE SURVEY

FACILITY NAME:

STREET ABDRESS:

CITY/STATE/ZIP:

TELEPHONE NO:

PERSON CONTACTED/TITLE:

TYPE OF FACILITY:

$\square$ ACADEMIC

MEDICAL

INDUSTRIAL

$\square$ OTHER DESCRIBE

SIZE OF FACILITY:

STUDENTS

BEDS

EMPLOYEES

PROCESS(ES) WHICH GENERATE WASTE:

IS WASTE TREATED BEFORE PACKAGING?

HOW?

HOW IS WASTE PACKAGED?

WHAT IS PRINCIPAL CHEMICAL \& PHYSICAL COMPOSITION OF WASTE?

HOW MANY WASTE SHIPMENTS DID YOU MAKE IN:

$$
\begin{aligned}
& 1978 \text { - } \\
& 1977 \text { - } \\
& 1976 \text { - }
\end{aligned}
$$

DO YOU EXPECT INCREASE OR DECREASE IN WASTE VOLUME?

PLEASE QUANTIFY WASTE DISPOSED OF IN CALENDAR YEARS 1978, 1977, 1976 ON REVERSE SIOE OF FORM. IF MORE SPACE WILL BE REQUIRED THAN IS AVAILABLE ON FORM, PLEASE PROVIDE IN SAME FORMAT ON BLANK SHEET OF PAPER. 
FIGURE 5-1 (Concluded)

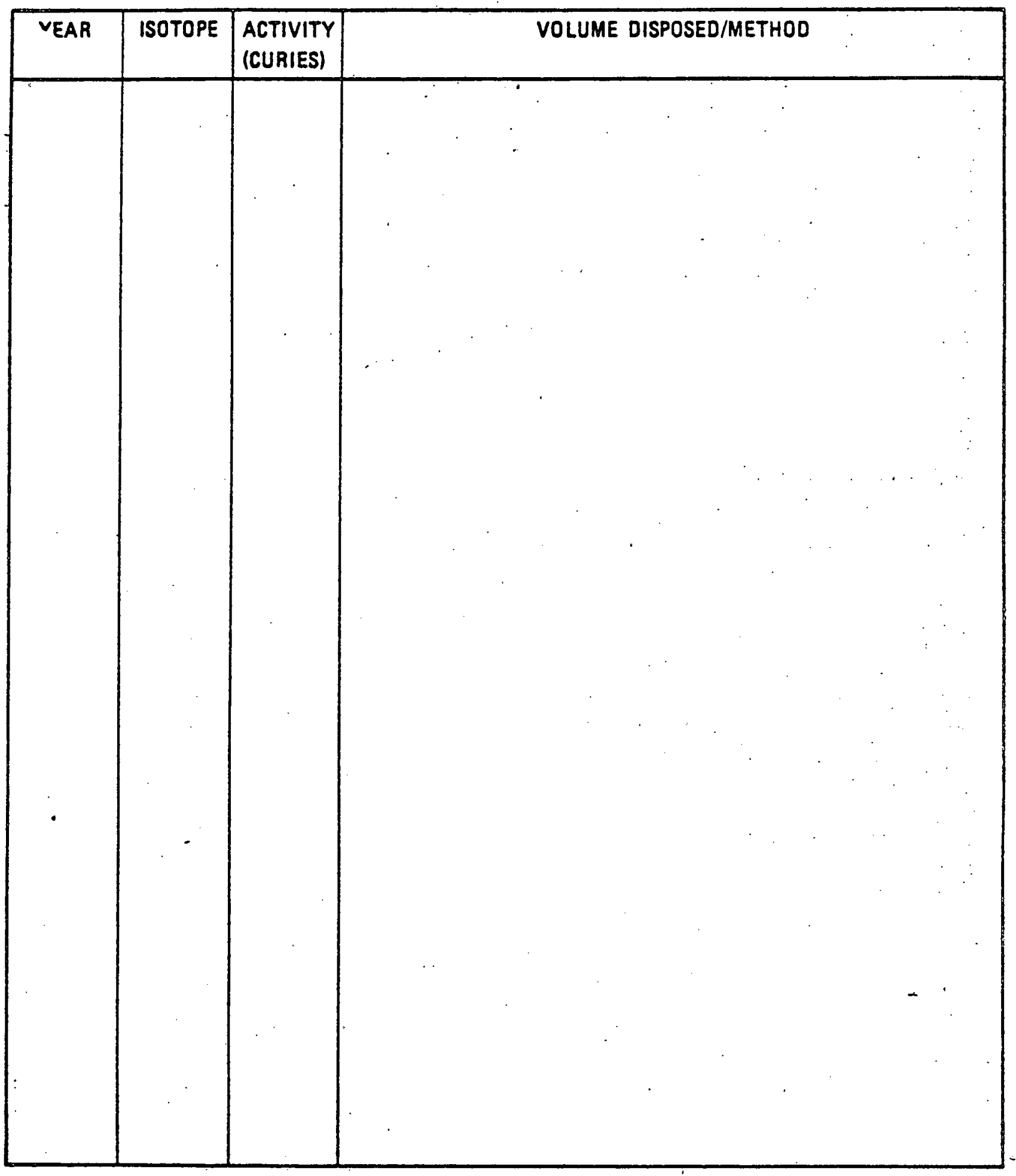

ADDITIONAL COMMENTS:

$5-3$

r 
FIGURE 5-2

TRANSMITTAL LETTER

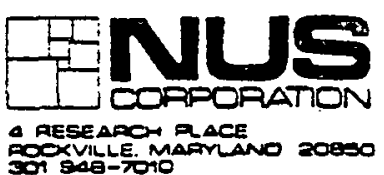

September 11, 1979

BDC-PE-275

St. Judith's Bospital

600 Beauregard Avenue

Danville, Jilinois 61832

Attr: Dr. J. M. Wilson

Subject: Survey of Low Level Radioactive Waste Disposal

Dear Dr. W11s0s:

Maintaining free access to proper low level radioactive waste disposal sites is becoming more difficult as individual state and local furisdictions seek to impose control upan or eliminate such activity.

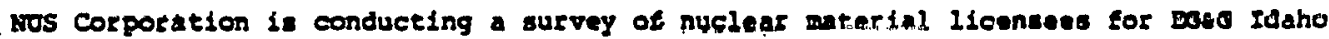
and the Department of gnergy to ascertain the volume and naturo of waste they generate. At the present time there is not an avallable data base for the long $r$ ange projections nocessary for proper planning of future lon level vaste disposal facilities.

Completion of the attached survay ford will enable wos to ganarnte wueh a dota base ser the 0.3. Covernment. Your cooperation will assist both your organization and other upers of radioactive materials in mintaining continued access to appropriate waste disposal sacllities.

If you bave any questions on the attached survey form or lts use, please foel troe to contact at 301/948-7010.

sincerely,

Bruce D. Guilbeault

Profect kanager

BDosdg

Enclosure 
FIGURE 5-3

\section{GENERAI DNSIRUCIONS}

1. The exclesed Radioactue Waste Survey fom us is salf-explaratory. the following instructons prowde general guldellnes. If you have ary spectic conceras, pleese call Brice Guibeault ar Don EIIl oz

$$
301-948-7010
$$

2. If posstble, all quantitative data should be taken difectly fou

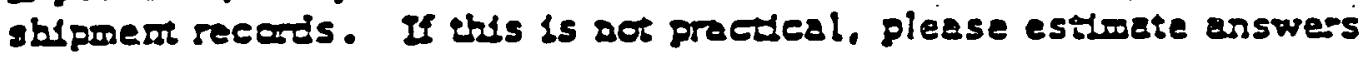
as accurately es posstie.

3. Pleese explain or spectfy enswers (where requested) es eoxpletely as possible. If additional space is reeded. pleese use the - Acditsonal commerts" secalon on the last page of uhis questronnet-e.

4. Wher you bave corpleted this questloaratre, please resura it in the enclesed stamped, self-eddressed envelope.

5. If your fectlity does rot dis pose of Radloactive Materals by use of the comertal redicocive meterial disposal sties, please flll out the sivvey farm with the amount of material recelved in eact yeer and where these Radioectue Mate-lals received were disposed (a.g. Isctopes used is patlem treatment residues decayed to beckground, disposed in trash. or shlpped out 18 flistshed product.)

TEANX YOU VERY MUCE FOR YOUR CO-OPERATION 
FIGURE 5-4

FORM USED FOR TABULATION

LICEVSEE YAME

NAME OF FACILTY

STREET ADORESS

CTY/STATE/ZAP

TELEPHONE NO.

PERSON SUPPLYING INFORMATION

TIRE

PART I - TYPE OF. FACILTTY

(CHECX THE ONE CATEGORY DHICH IS MOST APPLICABLE)

MEDICAL

a mospttal

口 PHARMACEUTTCAL MANUPACTURER

$\square$ VEDICAL RESEARCH/EDUCATTON

D OTHER (SPECAFY)

EDUCATIONAL

$\square$ UNTERSTT

$\square$ HІH SCHOOL

OTHER (SPECIFY)
INDUSTRIAL

D INCORPORATES RADIOACTIVTTY INTO PRODUCTS

D USES RADIOACTIVTY IN PROCESS CONTROL

D COMMERCUL POEER REACTOR

Q OTHER (SPECIFY)

COVERNMENTAI (NONHEDICA OR EDUCATIONAL)

D FEDRAL

D MLTTARY

DTATE

$\square$ LOCAL

PART II - DSPOOSAL METHOD

CHECX EACA DLSOSAL MFTHOD WHISY YOU DO EMPLOY

D SIIP TO COMMERCLL REPOSTORY

a RELASE TO SEWER

口 COMBINE VITH COMMON RERUSE

Q VENT TO ATMOSPHERE

$\square$ BURY ON-STR

Q RETURN TO VENDOR

D DISTRIBUTE IN PRODUCT FORM

D NO WASTE CENERATED

a other (SFEeIfy) 
FIGURE 5-4 (Continued)

PART WI - SOURCE OP RADIOACTIVE WASTE

(CHECX EACH SOURCE OF YOUR POTENTIAL RADIOACTIVE DASTE AND. IF YOU SHUP. DNDICATE THE PERCENTAGE OF YOUR TOTAL SHIPPED DASTE VOLUME ORIGINATING FROM EACH SOURCE CATEGORY)

SOURCE OF RADIOACTIVITY

PERCENT OF $\nabla A S T E$

VOLUME SHIPPED

D NUCLEAR REACTOR

D NEUTRON GENERATOR

D CYCLOTRON OR STMCHROTRON

D SEALD SOURCE

D UNSEALED RADIOACTTV MATERLAL

D NATURAL ORES OR MUL TARINGS

O OTHER (SPECIFY)

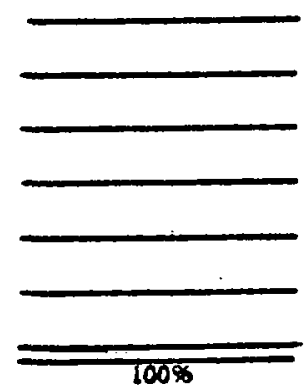

IP YOU DO NOT SHIP RADIOACTIVE WASTES. YOU HAVE COMPLETED THE QUESTIONNARE THANK YOU. DF YOU DO SHIP, PLEASE CONTINUE WITH THE FOLLOWINC QUESTIONS.

\section{PART IV - PHYSICAL FORM OF SHIPPED WASTES}

(CHECX EACH FORM OF WASTE WHICH YOU SHIP AND INDICATE THE PERCENTAGE OF YOUR TOTAL SHIPPED DASTE VOLUME REPRESENTING EACH FORM)

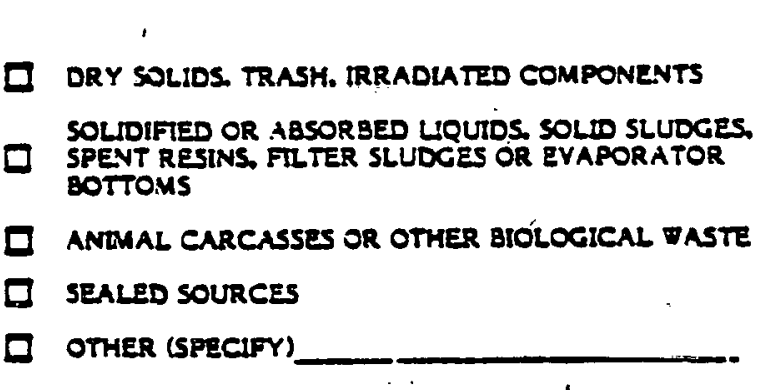

\section{PERCENT OF WASTE YOLUME SHIPPED}

DOES DASTE CONTAN ANY MATERLAL THICH IS POTENTIALLY:

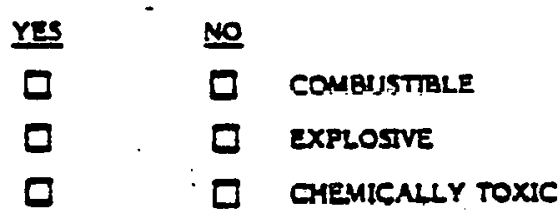

THAT SHIPPINC CONTAINERS DO YOU USE?
IS GALLON STEEI DRUMS
Q 30 GALLON STEEL DRUMS
OTHER (SPECIFY)

WHAT ONSITE PROCESSNG OF DASTE DO YOU EMPLOY?
D. vone
D heghanteal COMPACTION
D INCINERATION
SOLDIFCATION OR EYAPORATION OF LUQUTOS
ABSORṔtION OF LQUTDS
OTHER (SPECIFY) 
FIGURE 5-4 (Concluded).

PART V - WASTE QUANTITY

INDICATE TOTAL YEARLY VOLUME UN CUBIC PEETI OF TASTE SHIPPED TO A COMMERCULL DISPOSAL FACILITY.

\section{CUBIC PEET SHIPPED}

ACTUAL SHIPPED IN 1977

ACTUAL SHIPPED IN 1978

ACTUAL SHIPPED IN 1979

INDICATE TOTAL YEARLY VOLUME (IN CUBC FEET) OF WASTE PROJECTED TO BE CENERATED WHICH WILL BE SHIPPED.

\section{CUBIC FFET GENERATER}

ESTIMATED GENERATION IN 1980

ESTTMATED GEVERATTON IN 1985

ESTLMATED CENERATTON IN 1990

INDICATE THE QUANTITY OF RADIOACTIVITY (IN CURLES) SHIPPED TO A COMMERCIAL FACLITY IN THE YEARS 1977, 1978 ANO 1979.

\begin{tabular}{|l|l|l|l|}
\hline \multirow{2}{*}{ SSOTOPE } & \multicolumn{3}{|c|}{ QUANTITY SHLPPED (CURIES) IN: } \\
\hline & 197 & 1973 & 1979 \\
\hline & & & \\
\hline & & & \\
\hline & & & \\
\hline & & & \\
\hline & & & \\
\hline & & & \\
\hline & & & \\
\hline & & & \\
\hline & & & \\
\hline & & & \\
\hline
\end{tabular}




\subsection{USE OF COMMERCIAL LOW-LEVEL WASTE DISPOSAL FACILITIES}

In the state of Oregon, a total of 185 potential shippers of low-level radioactive waste were identified. These potential shippers were sent, by direct,' mail questionnaires concerning their waste management practices. The respondent was identified as either a medical, educational, industrial, power reactor, or governmental type facility. All but one of the potential shippers identified for the state of oregon were able to be grouped into one of these classifications of facilities. Section 2.0 presents the number of respondents using various disposal methods and the source of radioactivity used at facilities. Table 2-1 indicates that 18.7 percent ( 17 facilities) of the respondents use commercial low-level waste facilities. The following subsections present a sumary of the characteristics and quantity of wastes disposed of by these 17 facilities.

\subsection{RESPONSE TO SURVEY}

Table 6-1 presents, by facility type, the number of potential shippers surveyed, the total number and percentage of responses obtained, and a breakdown of responses by degree of response. If a facility provided at least the facility type and method of disposal, the answers were considered a response. If no information was obtained, the type of facility was determined by the facility name, if possible. If not, the type of facility was tabulated as "unknown." The responses were further categorized by degree of response into three groups. Group 1 responses were responses in which all appropriate information requested was provided (see Pigure 5-1). Group 2 responses provided only information on the type of facility, disposal method, and quantity of waste. Group 3 responses included only information on the type of facility and the disposal method.

Forty-nine percent of all potential shippers identified provided some degree of response. The percent of response between type of facility ranged from 39.6 percent for medical facilities to 75.0 percent for educational facilities. Of the respondents, 64.1 percent provided all requested information.

It should be noted that of the 94 potential shippers (out of 185) which did not provide any information, many of these may in fact be shippers. A decline to answer the questionnaire can be reasonably assumed to indicate that they in fact do 
ship wastes, since the only response and effort required if they do not ship wastes was to return the form. Accordingly, there is a high potential that the percent response to the survey from shippers may be as low as 15 percent ( 17 shipper respondents out of a total of 112 shippers or nonrespondents) rather than the 49 percent response from all potential shippers.

\subsection{SOURCES OP SHIPPED WASTE}

\subsubsection{Distribution by Type of Facilities Shipping Wastes}

Table 6-2 presents the distribution of numbers of facilities shipping wastes by major type of facility and by subgroup within each major type. In terms of number of facilities shipping wastes, medical facilities account for over 47 percent of all shippers, with educational facilities comprising 29 percent of all shippers.

\subsubsection{Origin of Radioactivity Resulting in Shipped Wastes}

The origin of radioactivity resulting in shipped waste was grouped into three categories: nuclear reactor operation, purchased as sealed sources, and purchased as unsealed radioactivity. Table 6-3 presents the distribution of number of facilities shipping wastes according to type of facility and origin of radioactivity. It should be noted that more than one origin may be appropriate for a given facility. Therefore, the total number of origins presented in Table 6-3 is greater than the total number of shippers of low-level waste. Over 88 percent of the facilities shipping waste obtain the radioactivity as unsealed radioactive material.

\subsection{VOLUME OF SHIPPED WASTE}

Volumes of low-level wastes shipped to commercial disposal facilities were provided by 14 facilities of the 17 respondents that indicated they shipped wastes. These 14 facilities represent 12.5 percent of the 112 potential shippers within the state (17 respondents and 95 non-respondents). Table 6-4 presents volumes of shipped wastes for the years 1976, 1977, and 1978 for each type of facility. 
The one operating power reactor within Oregon (Trojan station) generated the majority of waste volume, accounting for about 44 percent of all shipped waste in 1976, 61 percent in 1977, and 72 percent in 1978. This reactor started operating in May 1976. Thus, the 1978 data are most representative of current shipments.

Table 6-5 shows the number of facilities that expect to increase, decrease, or not change the volume of shipped waste. These data indicate that a small increase with time might be expected, continuing the trend shown in the 1976, 1977, and 1978 data.

Two additional power reactors (Pebble Springs 1 and 2 ) are scheduled to become operational in 1988 and 1990, respectively. Their operation would approximately triple the total waste volume generated within oregon.

\subsection{ACTIVITY OF SBIPPED WASTE}

Table 6-6 presents quantity of activity in the waste shipped for the years 1976, 1977, and 1978 for each type of facility. As with the volumes shipped, power reactors accounted for the vast majority of activity shipped, being as high as 99.2 percent in 1978. However, in 1977, the University of Oregon disposed of 2,200 curies of Cobalt -60 , which is expected to be an infrequent occurrence. This one shipment represents 96.4 percent of the total activity disposed of from oregon in 1977. Table 6-7 presents the distribution by radionuclides of activity shipped.

\subsection{PHYSICAL CRARACTERISTICS OF SEIPPED WASTE}

Onsite processing of low-level waste may be performed to either reduce the volume of the waste (compaction, incineration) or to remove free liquid (solidification, evaporation, absorption). Table 6-8 shows the number of facilities using these illethods. Only one of the 11 respondents indicated they used mechanical compaction or incineration for volume reduction. Over half of the facilities use absorption to handle free liquids.

Table 6-9 presents the type of shipping container used onsite to package waste for transport to disposal facilities. Most facilities use either 55-gallon or 30- 
gallon steel drums. Bowever, about 29 percent of the facilities (shown under "other" column) use simply cardboard boxes for small volumes of waste which are packaged in drums by the transporter.

Shipped waste was categorized as either dry, moist, biological, sealed, or other. Table 6-10 presents the number of facilities shipping waste in any of these categories. 
TABLE 6-1

RESPONSE TO DIRECT MAIL SURVEY

\begin{tabular}{|c|c|c|c|c|c|c|c|c|c|c|c|c|}
\hline \multirow[b]{3}{*}{$\begin{array}{c}\text { Type } \\
\text { of } \\
\text { facillty } \\
\end{array}$} & \multirow[b]{3}{*}{$\begin{array}{c}\text { Number } \\
\text { of } \\
\text { 11cen- } \\
\text { gees }\end{array}$} & \multirow[b]{3}{*}{$\begin{array}{c}\text { Number } \\
\text { of } \\
\text { respon- } \\
\text { dents }\end{array}$} & \multirow[b]{3}{*}{$\begin{array}{l}\text { Percent } \\
\text { response }\end{array}$} & \multirow{2}{*}{\multicolumn{9}{|c|}{$\frac{\text { Degree of Regponise }}{\text { Group } 2}$}} \\
\hline & & & & & & & & & \multicolumn{2}{|r|}{ Group 3} & \\
\hline & & & & Number & $\begin{array}{c}\text { Percent } \\
\text { of } \\
\text { licen- } \\
\text { gees }\end{array}$ & $\begin{array}{c}\text { Percent } \\
\text { of } \\
\text { respon- } \\
\text { dents }\end{array}$ & Number & $\begin{array}{c}\text { Percent } \\
\text { of } \\
\text { licen- } \\
\text { gees }\end{array}$ & $\begin{array}{l}\text { Percent } \\
\text { of } \\
\text { respon- } \\
\text { dents }\end{array}$ & Number & $\begin{array}{c}\text { Percent } \\
\text { of } \\
\text { licen- } \\
\text { Bees }\end{array}$ & $\begin{array}{c}\text { Percent } \\
\text { of } \\
\text { respon- } \\
\text { dents }\end{array}$ \\
\hline Medical & 53 & 21 & 39.6 & 14 & 7.6 & 15.4 & 6 & 3.2 & 6.6 & 1 & 0.5 & 1.1 \\
\hline Bducational & 16 & 12 & 75.0 & 8 & 4.3 & 0.8 & 2 & 1.1 & 2.2 & 2 & 2.1 & 2.2 \\
\hline Industr lal & 86 & 42 & 48.8 & 27 & 14.6 & 29.7 & 15 & 8.1 & 16.5 & 0 & 0.0 & 0.0 \\
\hline Power Reactor & $i$ & 1 & 100.0 & 1 & 0.5 & 1.1 & 0 & 0.0 & 0.0 & 0 & 0.0 & 0.0 \\
\hline Governmental & 28 & 15 & 53.6 & 9 & 4.9 & $9: 9$ & 5 & 2.7 & 5.5 & 1 & 0.5 & 1.1 \\
\hline Unknowm & 1 & - & - & - & - & - & - & - & - & - & - & - \\
\hline TOTAL & 185 & 91 & 49.2 & 59 & 31.9 & 64.1 & $: \quad 28$ & 15.1 & 30.8 & 4 & 2.2 & 44 \\
\hline
\end{tabular}


TABLE 6-2

TYPE OF FACILITIES SHIPPING LOW-LEVEL WASTE

\begin{tabular}{|c|c|c|c|c|}
\hline \multicolumn{2}{|c|}{ Type of Facility } & \multirow{2}{*}{$\begin{array}{l}\text { Number of } \\
\text { facilities } \\
\text { shipping }\end{array}$} & \multirow{2}{*}{$\begin{array}{l}\text { Percent } \\
\text { of all } \\
\text { shippers }\end{array}$} & \multirow{2}{*}{$\begin{array}{c}\text { Percent } \\
\text { of } \\
\text { facilities type }\end{array}$} \\
\hline Facility & Subgroup & & & \\
\hline Medical & $\begin{array}{c}\text { Eospital } \\
\text { Pharmaceutical } \\
\text { Research/Education } \\
\text { Other } \\
\text { Total }\end{array}$ & $\begin{array}{l}3 \\
0 \\
1 \\
4 \\
8\end{array}$ & $\begin{array}{r}17.6 \\
0.0 \\
5.0 \\
23.5 \\
47.1\end{array}$ & $\begin{array}{r}37.5 \\
0.0 \\
12.5 \\
50.0 \\
100.0\end{array}$ \\
\hline Educational & $\begin{array}{l}\text { University } \\
\text { Bigh School } \\
\text { Other } \\
\text { Total }\end{array}$ & $\begin{array}{l}5 \\
0 \\
0 \\
5\end{array}$ & $\begin{array}{r}29.4 \\
0.0 \\
0.0 \\
29.4\end{array}$ & $\begin{array}{r}100.0 \\
0.0 \\
0.0 \\
100.0\end{array}$ \\
\hline Industrial & $\begin{array}{l}\text { Product Use } \\
\text { Process Control } \\
\text { Other } \\
\text { Total }\end{array}$ & $\begin{array}{l}0 \\
1 \\
0 \\
1\end{array}$ & $\begin{array}{l}0.0 \\
5.9 \\
0.0 \\
5.9\end{array}$ & $\begin{array}{r}0.0 \\
100.0 \\
0.0 \\
100.0\end{array}$ \\
\hline Power Reactor & Total & 1 & 5.9 & 200.0 \\
\hline Governmental & $\begin{array}{l}\text { Pederal } \\
\text { Military } \\
\text { State } \\
\text { Local } \\
\text { Total }\end{array}$ & $\begin{array}{l}1 \\
0 \\
0 \\
1 \\
2 \\
2\end{array}$ & $\begin{array}{l}5.9 \\
0.0 \\
0.0 \\
5.9 \\
11.8\end{array}$ & $\begin{array}{r}50.0 \\
0.0 \\
0.0 \\
50.0 \\
200.0\end{array}$ \\
\hline TOtac & & 17 & 100.0 & 100.0 \\
\hline
\end{tabular}


TABLE 6-3

ORIGIN OF RADIOACTIVITY RESULTING IN SHIPPED WASTES

\begin{tabular}{|c|c|c|c|c|c|c|c|}
\hline \multirow[b]{2}{*}{$\begin{array}{c}\text { Type } \\
\text { of } \\
\text { facility }\end{array}$} & \multirow[b]{2}{*}{$\begin{array}{l}\text { Number } \\
\text { of } \\
\text { respon- } \\
\text { dents } \\
\end{array}$} & \multicolumn{2}{|c|}{$\begin{array}{l}\text { Nuclear } \\
\text { reactor }\end{array}$} & \multicolumn{2}{|c|}{$\begin{array}{l}\text { Sealed } \\
\text { sources }\end{array}$} & \multicolumn{2}{|c|}{$\begin{array}{l}\text { Onsealed } \\
\text { radioactive } \\
\text { material }\end{array}$} \\
\hline & & $\begin{array}{c}\text { Number } \\
\text { of } \\
\text { sources* }\end{array}$ & $\begin{array}{l}\text { Percent } \\
\text { of all } \\
\text { shippers }\end{array}$ & $\begin{array}{c}\text { Number } \\
\text { of } \\
\text { sources }\end{array}$ & $\begin{array}{l}\text { Percent } \\
\text { of all } \\
\text { shippers }\end{array}$ & $\begin{array}{c}\text { Number } \\
\text { of } \\
\text { sources* }\end{array}$ & $\begin{array}{l}\text { Percent } \\
\text { of all } \\
\text { shippers }\end{array}$ \\
\hline Medical & 8 & 0 & 0.0 & 0 & 0.0. & 8 & 47.1 \\
\hline Educational & 5 & 0 & 0.0 & 0 . & 0.0 & 5 & 29.4 \\
\hline Industrial & 1 & 0 & 0.0 & 1 . & 5.9 & 0 & 0.0 \\
\hline Power Reactor & 1 & 0 & 0.0 & 0 . & 0.0 & 0 & 0.0 \\
\hline Governmental & 2 & 1 & 5.9 & 0 & 0.0 & 2 & 11.8 \\
\hline TOTAL & 17 & 1 & 5.9 & 1 & 5.9 & 15 & 88.2 \\
\hline
\end{tabular}

*The total of "number of sources" exceeds the total number of respondents due due to facilities generating waste from several sources. 
TABLE 6-4

VOLUME OP SHIPPED WASTE

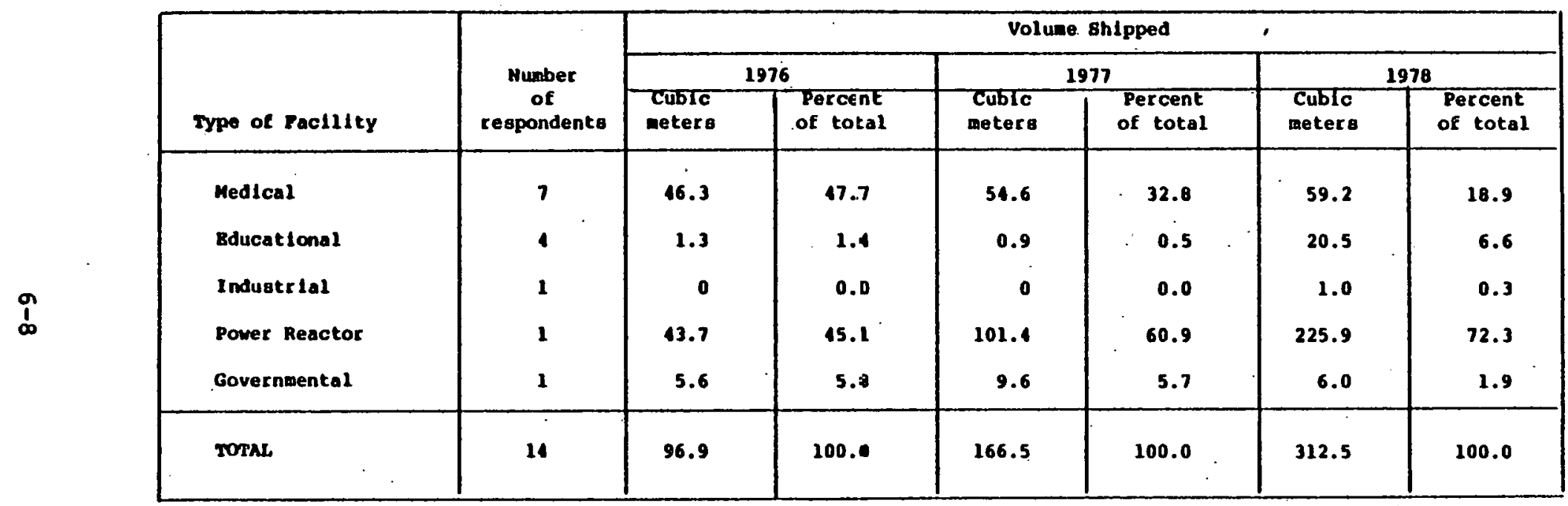


TABLE 6-5

PROJECTED CHANGE IN VOLUME OF SHIPPED WASTE

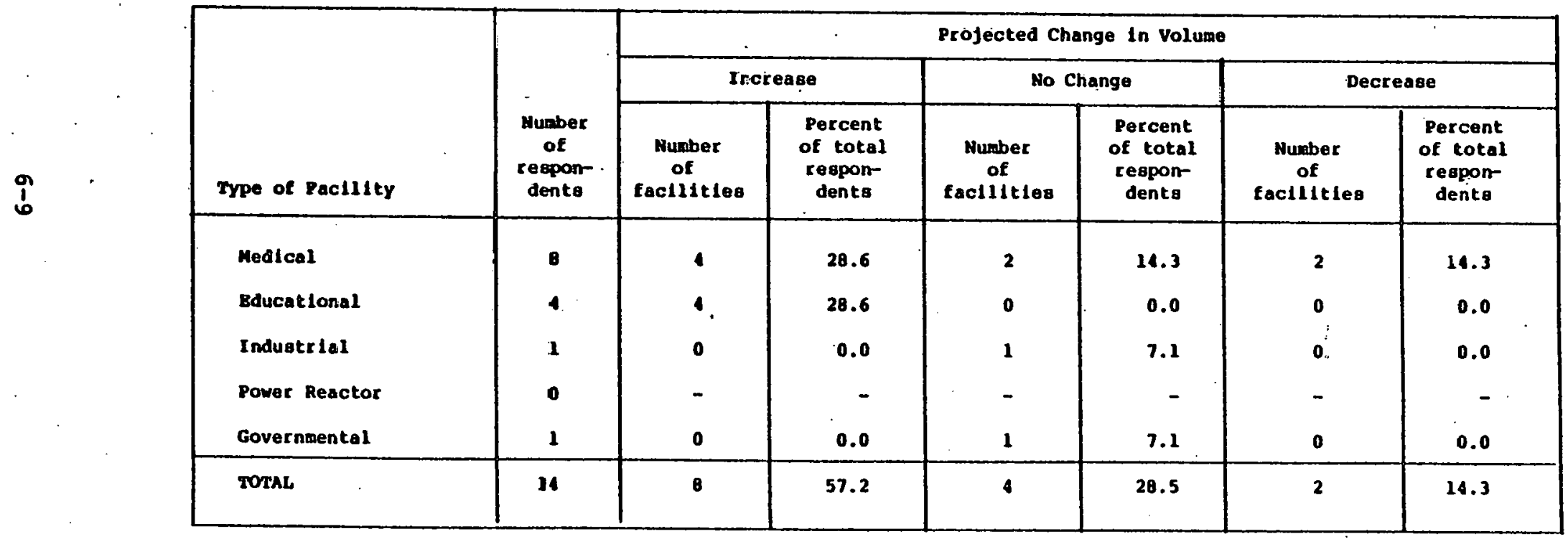


TABLE 6-6

ACTIVITY OF SHIPPED WASTE

\begin{tabular}{|c|c|c|c|c|c|c|c|}
\hline \multirow[b]{3}{*}{ Type of Pacllity } & \multirow{3}{*}{$\begin{array}{l}\text { Huaber } \\
\text { of } \\
\text { respon- } \\
\text { dents }\end{array}$} & \multicolumn{6}{|c|}{ Activity shipped } \\
\hline & & \multicolumn{2}{|c|}{1976} & \multicolumn{2}{|c|}{1977} & \multicolumn{2}{|c|}{1978} \\
\hline & & Curles & $\begin{array}{l}\text { Percənt } \\
\text { of tctal }\end{array}$ & Curier & $\begin{array}{l}\text { Percent } \\
\text { of total }\end{array}$ & Curles & $\begin{array}{l}\text { Percent } \\
\text { of total }\end{array}$ \\
\hline Medical & 7 & $5.08-1$ & 6.9 & $5.5 \mathrm{E}-1$ & 0.0 & $5.78-1$ & 0.1 \\
\hline Bducatlonal & 4 & $4.7 \mathrm{~B}-1$ & 6.5 & $2.2 \mathrm{~B}+3$ & 96.4 & $1.2 E+0$ & 0.3 \\
\hline Industriol & 1 & 0.0 & 0.0 & 0.0 & 0.0 & $1.25 \mathrm{E}-3$ & 0.0 \\
\hline Power Reactor & 1 & $6.2 \mathrm{E}+0$ & 86.6 & $8.4 B+1$ & 3.6 & $4.5 E+2$ & 99.2 \\
\hline Governmental & 1 & $8.8 \mathrm{E}-4$ & 0 & $2.3 \mathrm{~B}-3$ & 0.0 & $2.0 \mathrm{E}+0$ & .4 \\
\hline TOTAL & 14 & $7.28+0$ & 100.0 & $2.3 E+3$ & 100.0 & $4.58+2$ & 100.0 \\
\hline
\end{tabular}


Table 6-7

RADIONUCLIDES IN SHIPPED WASTES

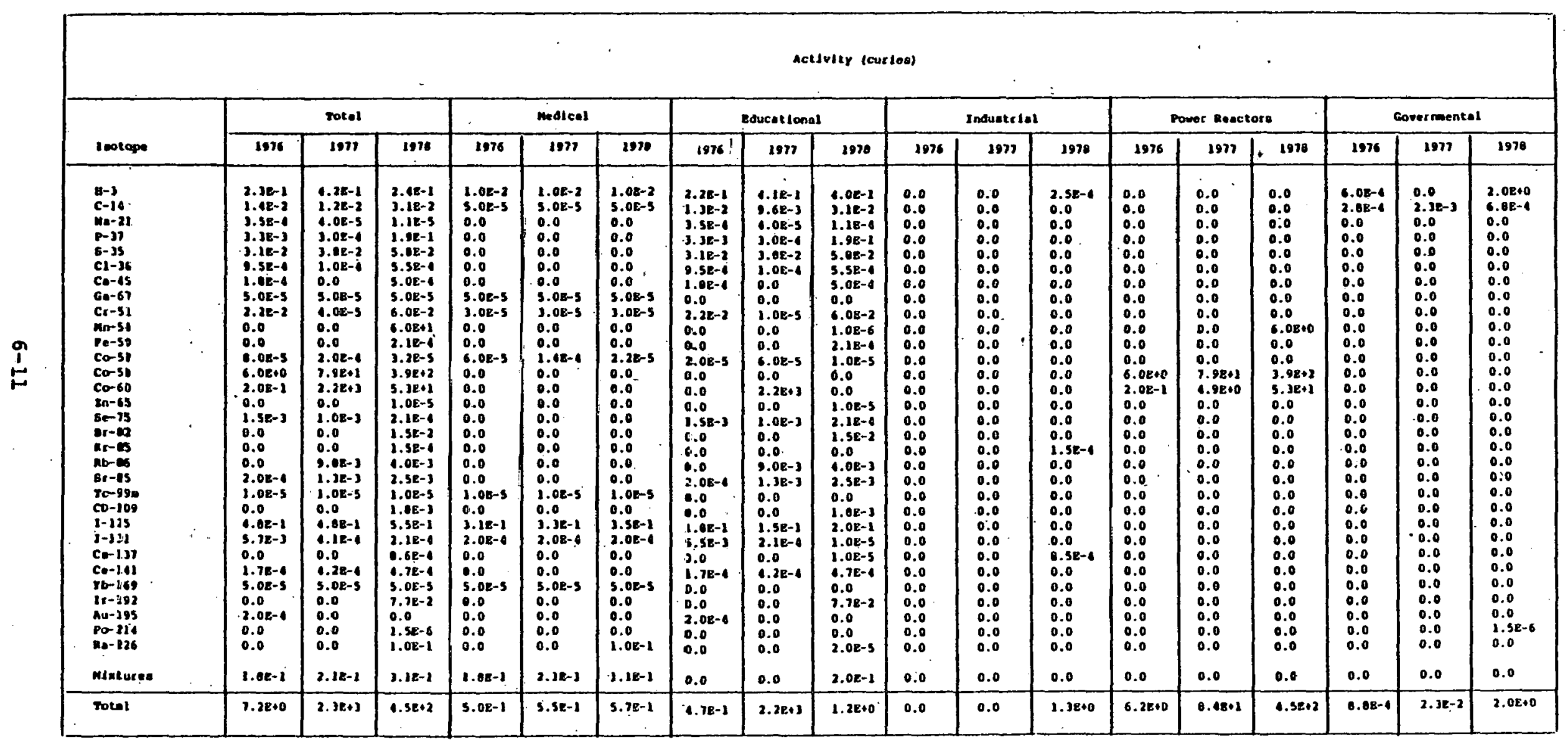


TABLE 6-8

ONSITE PROCESSING OF SHIPPED WASTE

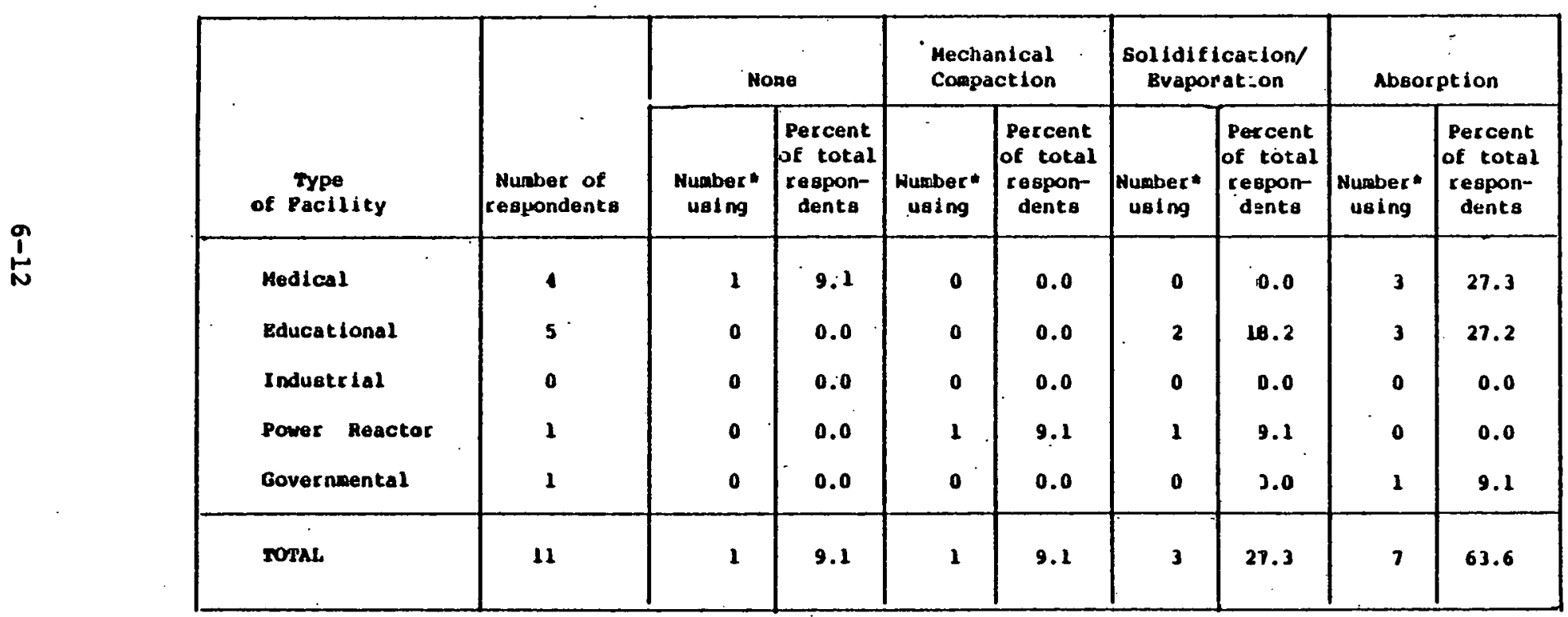

"The total of "number using" exceeds the total number of respondents due to the use of Beveral practices at each facility. 
TABLE 6-9

SHIPPING CONTAINER USED

\begin{tabular}{|c|c|c|c|c|c|c|c|}
\hline \multirow[b]{2}{*}{$\begin{array}{c}\text { Type } \\
\text { of Facility }\end{array}$} & \multirow[b]{2}{*}{$\begin{array}{l}\text { Number } \\
\text { of } \\
\text { respon- } \\
\text { dents }\end{array}$} & \multicolumn{2}{|c|}{ 55-gal. drums } & \multicolumn{2}{|c|}{ 30-gal. drums } & \multicolumn{2}{|c|}{ Others } \\
\hline & & $\begin{array}{l}\text { Number } \\
\text { using }\end{array}$ & $\begin{array}{l}\text { Percent } \\
\text { of total } \\
\text { respon- } \\
\text { dents }\end{array}$ & $\begin{array}{l}\text { Number } \\
\text { using }\end{array}$ & $\begin{array}{l}\text { Percent } \\
\text { of total } \\
\text { respon- } \\
\text { dents }\end{array}$ & $\begin{array}{l}\text { Number * } \\
\text { using }\end{array}$ & $\begin{array}{l}\text { Percent } \\
\text { of total } \\
\text { respon- } \\
\text { dents }\end{array}$ \\
\hline Medical & 6 & 4 & 28.6 & 2 & 14.3 & 1 & 7.1 \\
\hline Educational & 5 & 4 & 28.6 & 1 & 7.1 & 2 & 14.3 \\
\hline Industrial & 1 & 0 & 0.0 & 0 . & $=0.0$ & 1 & 7.1 \\
\hline Power Reactor & 1 & 1 & 7.1 & 0 & 0.0 & 0 & 0.0 \\
\hline Governmental & 1 & 1 & 7.1 & 0 & 0.0 & 0 & 0.0 \\
\hline TOTAL & .14 & 10 & 71.4 & 3 & 21.8 & 4 & 28.6 \\
\hline
\end{tabular}

"The total of "number using" exceeds the total number of respondents due to several types of containers being used at some facilitles. 
TABLE 6-10

PHYSICAL FORM OF SHIPPED WASTE

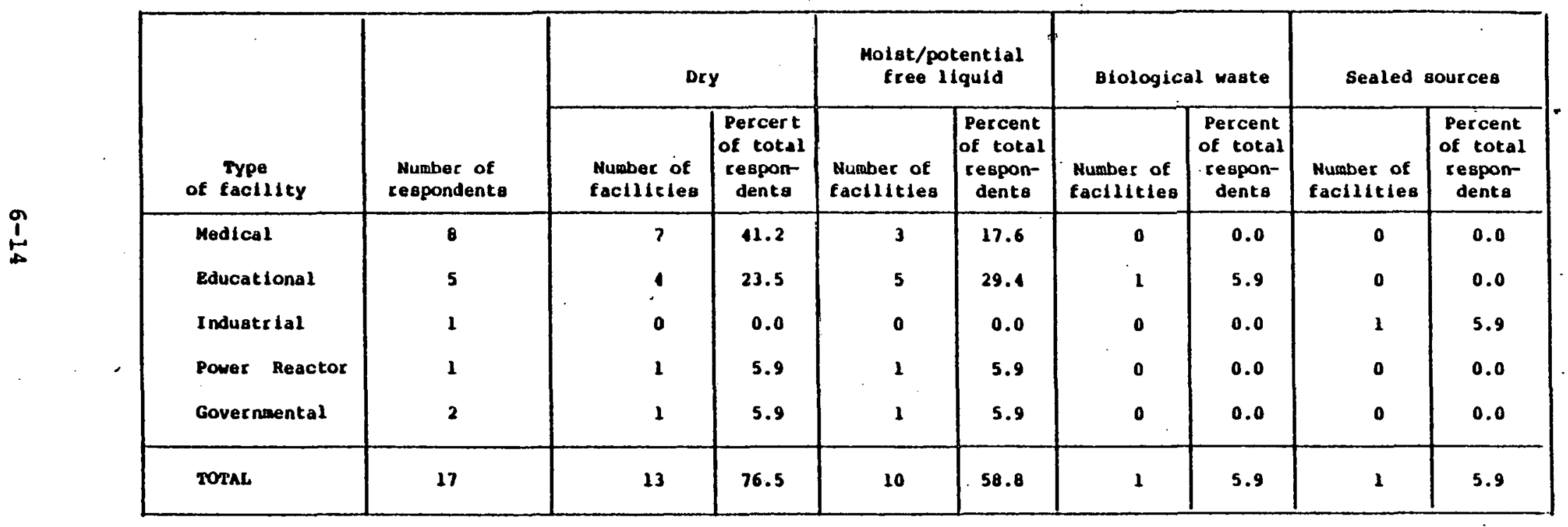

"The total of "number of facilitles" exceeds the total number of respondents due to waste being in several forms at some facilities. 
APPENDIX A

RADIOACTIVE MATERIAL LICENSEES

IN THE STATE OF OREGON

$A-1$ 
Column 1:

Column 2:

Column 3:

Column 4:

Column 5 :
Name and address as provided by the Idaho Department of Health and Welfare

$\mathbf{N}$ indicates questionnaire was not delivered as evidenced

by package being returned by postal service

$Y$ indicates questionnaire was mailed and not returned by the postal service

$N$ indicates that no response to the written questionnaire was received

1 indicates the 1 icensee did respond and provided all appropriate information

2 indicates the licensee did respond but provided only information on type of Eacillty, disposal method, and quantity of waste

3 indicates the licensee did respond but provided only information on type of facility and disposal method

$$
\begin{aligned}
& \mathbf{M}=\text { Medical } \\
& \mathbf{E}=\text { Educational } \\
& \mathbf{I}=\text { Industrial } \\
& \mathbf{P}=\text { Power Reactor } \\
& \mathbf{G}=\text { Governmental } \\
& \mathbf{D}=\text { Onknown }
\end{aligned}
$$

$Y$ indicates the licensee ships wastes to a commercial disposal site

$\mathbf{N}$ indicates the Iicensee does not ship wastes

- indlcates information not available 


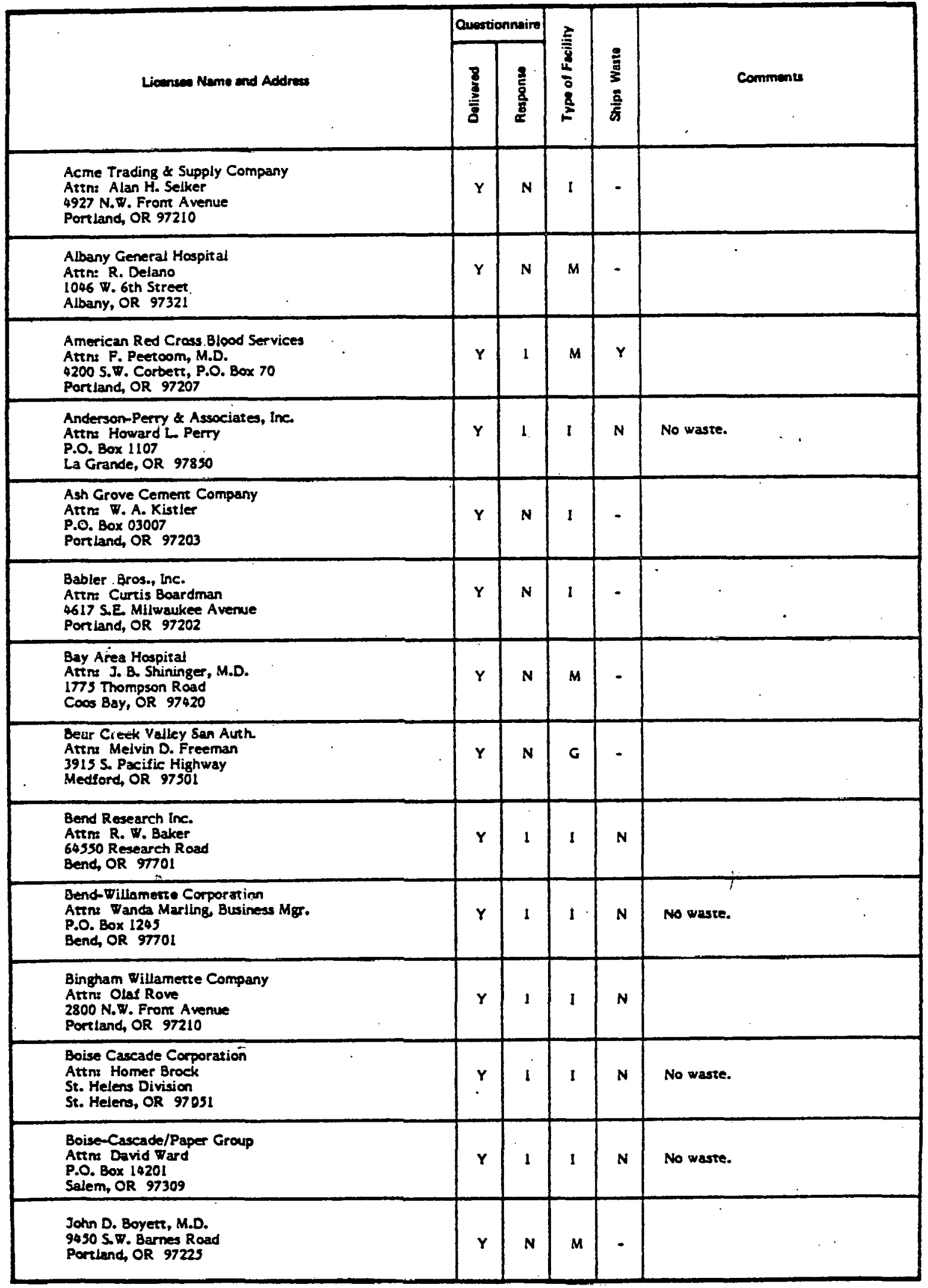




\begin{tabular}{|c|c|c|c|c|c|}
\hline \multirow[b]{2}{*}{ 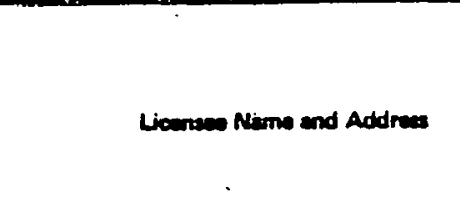 } & \multicolumn{2}{|c|}{ Ouncionnaire } & \multirow{2}{*}{$\begin{array}{l}\frac{E}{\bar{z}} \\
\frac{2}{0} \\
\frac{8}{2}\end{array}$} & \multirow{2}{*}{$\begin{array}{l}\frac{5}{3} \\
\frac{5}{6}\end{array}$} & \multirow[b]{2}{*}{ Comments } \\
\hline & $\frac{8}{3}$ & $\frac{2}{8}$ & & & \\
\hline $\begin{array}{l}\text { Brooks-Scanion, Inc. } \\
\text { Attn: David Miller } \\
\text { P.0. Box } 1111 \\
\text { Bend, OR } 97701\end{array}$ & $\mathbf{Y}$ & 1 & 1 & $\mathbf{N}$ & No waste. \\
\hline $\begin{array}{l}\text { lan A. Brown, M.D., P.C. } \\
\text { Grant Building Swite A } \\
9370 \text { S. W. Greenburg Road } \\
\text { Portland, OR } 97223\end{array}$ & $Y$ & $N$ & $M$ & - & \\
\hline $\begin{array}{l}\text { Carlson Testing, Inc. } \\
\text { Attn: Douglas Leach } \\
\text { P.O. Bax } 23814 \\
\text { Tigard, OR } 97223\end{array}$ & $\mathbf{Y}$ & $\mathbf{N}$ & 1 & - & \\
\hline $\begin{array}{l}\text { Cascade Construction Company, Inc. } \\
\text { Aitins Brlan J. Kialber } \\
\text { P.O. Box } 4267 \\
\text { Portland, OR } 97208\end{array}$ & $\mathbf{Y}$ & $\mathbf{N}$ & I & - & ? \\
\hline $\begin{array}{l}\text { Cascade Steel Rolling Mills } \\
\text { Amn: Bull Brantly } \\
3200 \text { N. Highway } \\
\text { McMimville, OR } 97128\end{array}$ & $\mathbf{Y}$ & 1 & $\mathbf{I}$ & $\mathbf{N}$ & No waste. \\
\hline $\begin{array}{l}\text { Century Testing Laboratories } \\
\text { Attn: Dave Newton } \\
\text { P.O.Box } 1174 \\
\text { Bend, OR } 97701\end{array}$ & $\mathbf{Y}$ & $\mathbf{N}$ & I & - & . \\
\hline $\begin{array}{l}\text { Cemtury Weat Engineering } \\
\text { Attns Rainse E. Anderson } \\
\text { P.O. Box } 1174 \\
\text { Bend, OR } 97701\end{array}$ & $Y$ & 1 & 1 & $\mathbf{N}$ & . \\
\hline $\begin{array}{l}\text { Champion Building Products } \\
\text { Attn: Don Judd } \\
4780 \text { Dee Highway } \\
\text { Hod River, UR } 97031\end{array}$ & $\mathbf{Y}$ & $\mathbf{N}$ & I & - & . \\
\hline $\begin{array}{l}\text { Chinook Research Labs, Inc. } \\
\text { Attn: Russell Korvola } \\
\text { P.O. Box } 1392 \\
\text { Corvalli, OR } 97330 \\
\end{array}$ & $\mathbf{Y}$ & $N$ & 1 & - & \\
\hline $\begin{array}{l}\text { James S. Christian } \\
14820 \text { N. } \nabla \text {. Ridgetop Court } \\
\text { Beavetom, OR } 97005\end{array}$ & $\mathbf{Y}$ & $\mathbf{N}$ & $u$ & - & \\
\hline $\begin{array}{l}\text { Wastewater Treatment Plant } \\
408 \text { N.E Waverly Drive } \\
\text { Albany, OR } 97321\end{array}$ & $\mathbf{Y}$ & 1 & G & $\mathbf{N}$ & No waste: \\
\hline 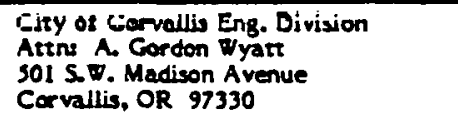 & $\mathbf{Y}$ & 1 & $\mathbf{G}$ & $\mathbf{N}$ & \\
\hline $\begin{array}{l}\text { City af Grames Pass } \\
\text { Attrs Harry } \Psi . \text { Chester } \\
\text { 101 N, } \Psi . A \text { Strem } \\
\text { Grants Pase, OR } 97526\end{array}$ & $\mathbf{Y}$ & 1 & G & N & - \\
\hline $\begin{array}{l}\text { City of Gresham } \\
\text { Atrns Stan Van Der Zanden } \\
150 \text { W. Powell } \\
\text { Gresham, OR } 97030\end{array}$ & $\mathbf{Y}$ & $\mathbf{N}$ & G & - & \\
\hline
\end{tabular}




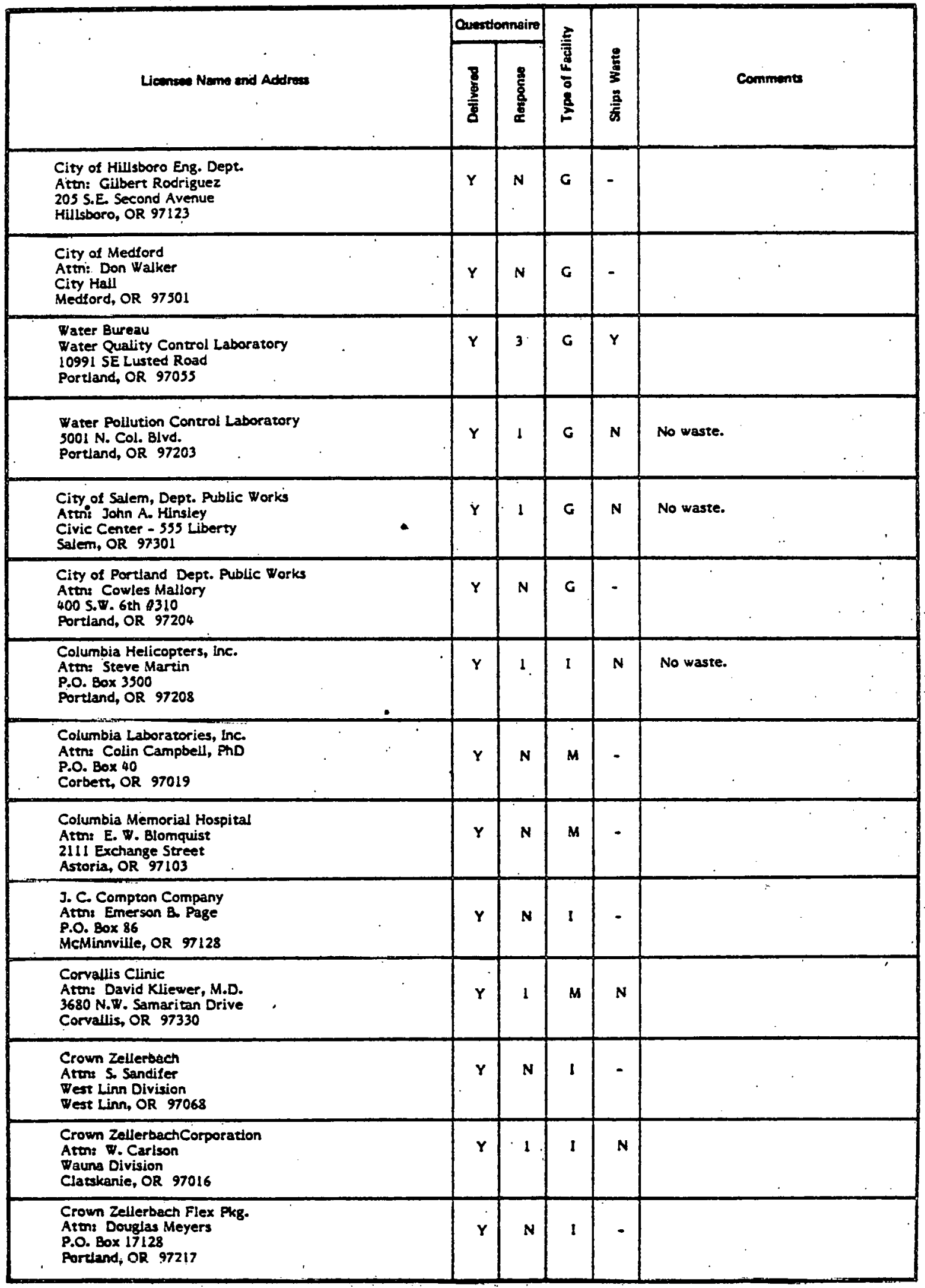




\begin{tabular}{|c|c|c|c|c|c|}
\hline \multirow[b]{2}{*}{ Liemsen Neme and Addrase } & \multicolumn{2}{|c|}{ Questionnairs } & \multirow{2}{*}{$\begin{array}{l}\underline{\underline{5}} \\
\mathbf{4} \\
\overline{0} \\
\frac{2}{2} \\
0\end{array}$} & \multirow{2}{*}{ 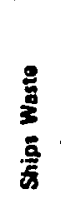 } & \multirow[b]{2}{*}{ Comment: } \\
\hline & $\frac{8}{8}$ & $\frac{2}{8}$ & & & \\
\hline $\begin{array}{l}\text { Dames \& Moore } \\
\text { Attn: Randolph S. Jarigese } \\
1220 \text { 5. } w \text {. Morrison } \\
\text { Portland, OR } 97205\end{array}$ & $\mathbf{Y}$ & $\mathbf{N}$ & 1 & - & . \\
\hline $\begin{array}{l}\text { Gilmore Steel Direct Reduction Dlvision } \\
\text { Atth: R. Brener } \\
14141 \text { N. Rivergate Blvo. } \\
\text { Portland, OR } 97203\end{array}$ & $\mathbf{Y}$ & 1 & 1 & $\mathbf{N}$ & No waste. \\
\hline $\begin{array}{l}\text { Douglas County Dept. Public Works } \\
\text { Attn: James F. Gosson } \\
\text { Room 103, Justice Hall } \\
\text { Roseburg, OR } 97470\end{array}$ & $\mathbf{Y}$ & 1 & G & $\mathbf{N}$ & No waste. \\
\hline $\begin{array}{l}\text { Dougias Community Hospital } \\
\text { Attn: Victor J. Vik, M.D. } \\
738 \text { W. Harvard Blvd. } \\
\text { Roseburg, OR } 97.470\end{array}$ & $\mathbf{Y}$ & $\mathbf{N}$ & $\mathbf{M}$ & - & v \\
\hline $\begin{array}{l}\text { Duraflake Company } \\
\text { Atm: Ray Bart } \\
\text { P.O. Box } 428 \\
\text { Albany, OR } 97321\end{array}$ & $\mathbf{Y}$ & 1 & 1 & $\mathbf{N}$ & \\
\hline $\begin{array}{l}\text { Dwyer Memorial Hospital } \\
\text { Atm: Stuart Rosenthal, M.D. } \\
\text { 10150 S.E } 32 \text { nd Avenue } \\
\text { Milwaukie, OR } 97222\end{array}$ & $\mathbf{Y}$ & $\mathbf{N}$ & $\mathbf{M}$ & - & . \\
\hline $\begin{array}{l}\text { Eastern Oregon Srare College } \\
\text { Attr: Gerald E. Young } \\
\text { Lagrande, OR } 97850\end{array}$ & $Y$ & 1 & $E$ & $\mathbf{N}$ & - \\
\hline $\begin{array}{l}\text { Eastmoreland General Hospital } \\
\text { Attn: Roger Zumwalt, Admin. } \\
2900 \text { S. E. Steele Strees } \\
\text { Portland, OR } 977 n ?\end{array}$ & $\mathbf{Y}$ & $\mathbf{N}$ & $M$ & - & \\
\hline $\begin{array}{l}\text { Emanuel Hospital } \\
\text { Attn: N.A. Pickering, M.D. } \\
2801 \text { N. Gantenbein Avenue } \\
\text { Portland, OR } 97227\end{array}$ & $\mathbf{Y}$ & $\mathbf{N}$ & $M$ & - & \\
\hline $\begin{array}{l}\text { EScO Corporation } \\
\text { Attr: Larry Buzan } \\
2141 \text { N.W. 25th Avenue } \\
\text { Portland, OR } 97210\end{array}$ & $\mathbf{Y}$ & $\mathbf{N}$ & I & - & . \\
\hline $\begin{array}{l}\text { Eugene Hospital-Clinic } \\
\text { Attri F. L. Benoit, M.D. } \\
1162 \text { willamerte Street } \\
\text { Eugene, OR } 97401\end{array}$ & $\mathbf{Y}$ & $\mathbf{N}$ & $\mathbf{M}$ & $\cdot$ & \\
\hline $\begin{array}{l}\text { Evans Products Company, Glass Plant } \\
\text { Atm: Mike Long } \\
\text { 1551 S.E Crysta Lake Drive } \\
\text { Corvallis. OR } 97330\end{array}$ & $\mathbf{Y}$ & 1 & 1 & $\mathbf{N}$ & \\
\hline $\begin{array}{l}\text { Mathews 8. Fish, M.D. } \\
\text { P.O. Box } 369 \\
\text { Eugene, OR } 97401\end{array}$ & $\mathbf{Y}$ & I & $\mathbf{M}$ & $\mathbf{N}$ & $\begin{array}{l}\text { Same as Sacred Heart General } \\
\text { Hospital. }\end{array}$ \\
\hline $\begin{array}{l}\text { Flightcraft, Inc. } \\
\text { Attr: Alan F. Roberts } \\
7505 \text { N.E Airport Way } \\
\text { Portland, OR } 97218\end{array}$ & $\mathbf{Y}$ & 1 & I & $\mathbf{N}$ & . \\
\hline
\end{tabular}




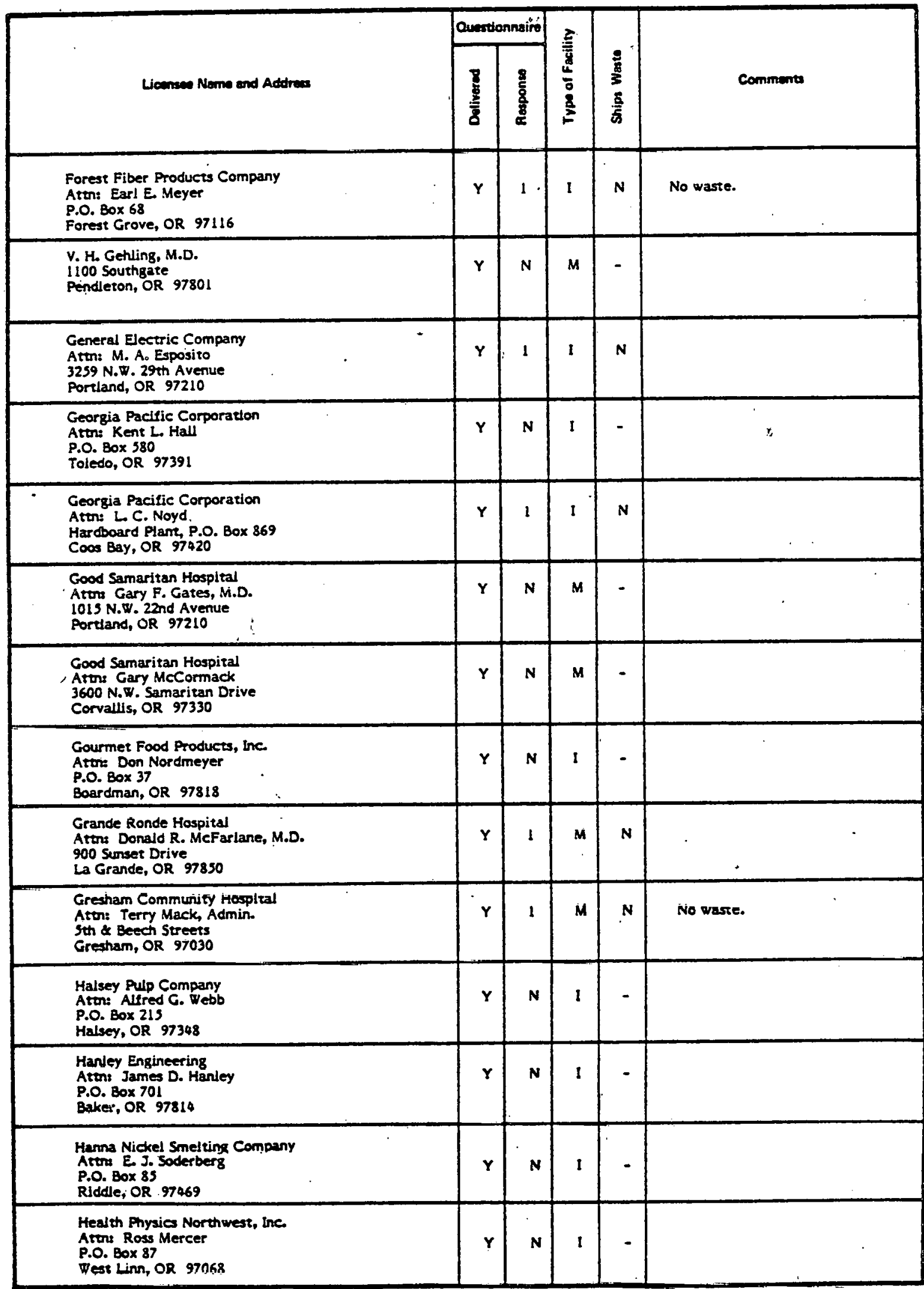




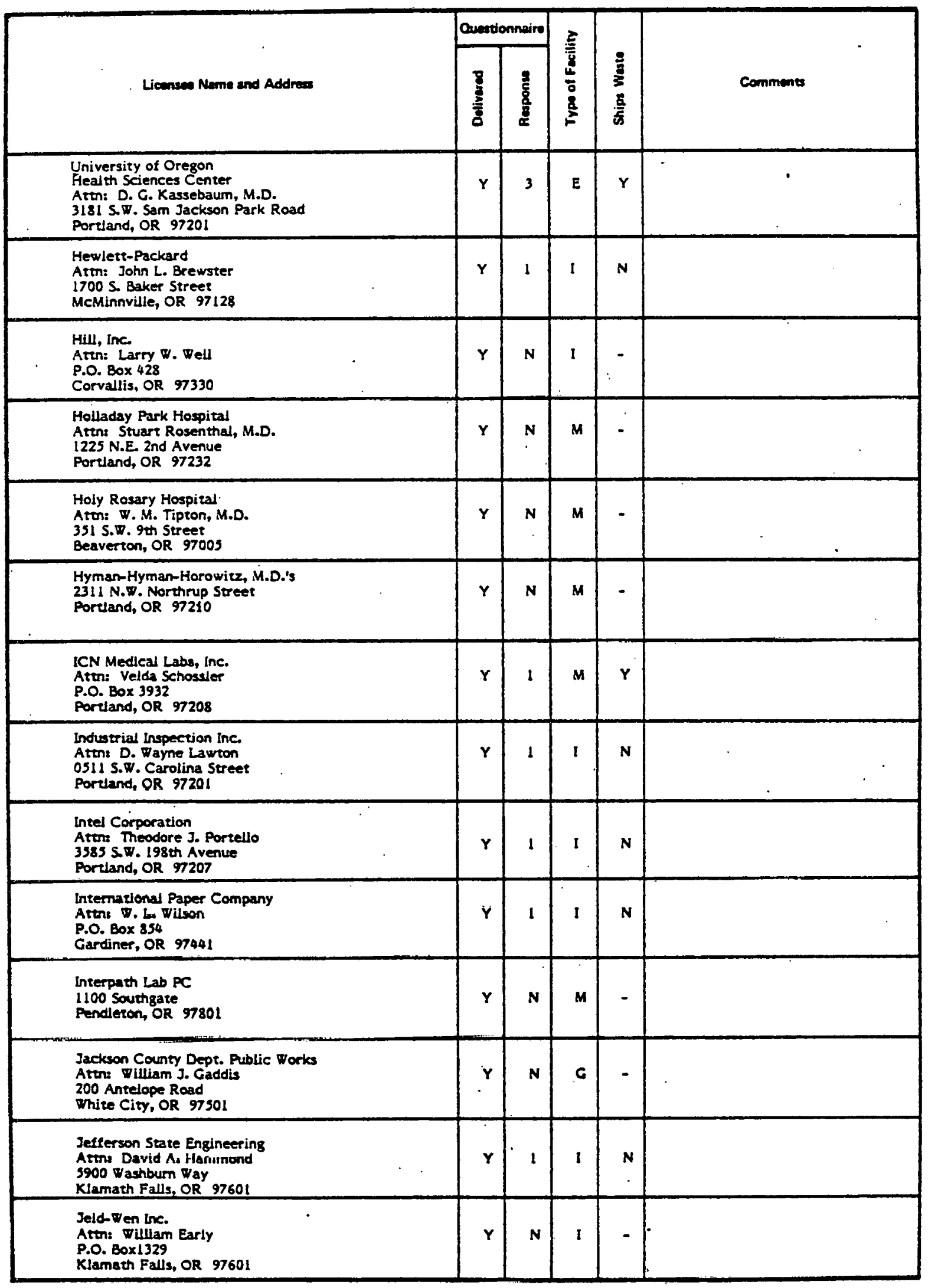




\begin{tabular}{|c|c|c|c|c|c|}
\hline \multirow[b]{2}{*}{ Liconseo Name and Address } & \multicolumn{2}{|c|}{ Questionnaire } & \multirow{2}{*}{ 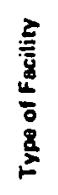 } & \multirow{2}{*}{ 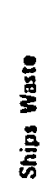 } & \multirow[b]{2}{*}{ Comments } \\
\hline & $\frac{8}{8}$ & $\frac{2}{8}$ & & & \\
\hline $\begin{array}{l}\text { Josephine General Hospital } \\
\text { Artn: Jon Gove, M.D. } \\
715 \text { N.W. Dimick } \\
\text { Grants Pass, OR } 97526\end{array}$ & $Y$ & 1 & M & $N$ & \\
\hline $\begin{array}{l}\text { Kaiser Foundation Hospital } \\
\text { Attn: Daniel M. Baer, M.D. } \\
\text { 3055 N. Greeley Avenue } \\
\text { Portland, OR } 97217\end{array}$ & $\mathbf{Y}$ & 1 & M & $\mathbf{N}$ & \\
\hline $\begin{array}{l}\text { LaGrand Industrial Supply } \\
\text { Attn: Louis La Grand } \\
\text { P.O. Box } 8053 \\
\text { Portland, OR } 97201\end{array}$ & $Y$ & 1 & 1 & $N$ & Resale only. \\
\hline $\begin{array}{l}\text { Lamb-Weston } \\
\text { Division of AMFAC Foods, Inc. } \\
\text { P.O. Box } 705 \\
\text { Hermiston, OR } 97838\end{array}$ & $\mathbf{Y}$ & $\mathbf{N}$ & 1 & - & $\cdot$ \\
\hline $\begin{array}{l}\text { Lamb-Weston, Inc. } \\
\text { Attn: G. B. Jacobsen } \\
6600 \text { S. W. Hampton Street } \\
\text { Portland, OR } 97723\end{array}$ & $Y$ & $\mathbf{N}$ & 1 & - & \\
\hline $\begin{array}{l}\text { Merpath } \\
\text { Atrn: Siegfried Heller } \\
3324 \text { N.E. Sand Blvd. } \\
\text { Portland, OR } 97220\end{array}$ & $Y$ & 1 & $M$ & $\mathbf{N}$ & No longer have any sources. \\
\hline $\begin{array}{l}\text { Lane Co. Dept. Public Works } \\
\text { Attn: James Jeppesen, Jr. } \\
3040 \text { N. Celta Highway } \\
\text { Eugene, OR } 97401\end{array}$ & $\mathbf{Y}$ & 1 & $\mathbf{G}$ & $\mathbf{N}$ & . \\
\hline $\begin{array}{l}\text { Lane Co. Environmental Health } \\
\text { Arth: Richard A. Kirby } \\
129 \text { East } 8 \text { th Avenue } \\
\text { Eugene, OR } 97401\end{array}$ & $\mathbf{Y}$ & 1 & $\mathbf{G}$ & $\mathbf{N}$ & . \\
\hline $\begin{array}{l}\text { Lewis \& Clark College } \\
\text { Atrn: James H. Karje } \\
\text { O615 5. } \mathbf{} \text {. Palatine Hill Road } \\
\text { Porvland, OR } 97219\end{array}$ & $Y$ & 1 & $\mathbf{E}$ & $\mathbf{N}$ & . \\
\hline $\begin{array}{l}\text { Linfield College } \\
\text { Attn: Robert Jones } \\
\text { Me.Minnville, OR } 97128\end{array}$ & $Y$ & 1 & $\mathbf{E}$ & $\mathbf{N}$ & \\
\hline $\begin{array}{l}\text { Linn-Benton Community College } \\
\text { Attn: Dr. Peter C. Scott } \\
6500 \text { S. } \mathbf{T} \text {. Pacific Blvd. } \\
\text { Albany, OR } 97320\end{array}$ & $\gamma$ & 1 & $\mathbf{E}$ & $\mathbf{N}$ & \\
\hline $\begin{array}{l}\text { Linn County Engineet } \\
\text { Attn: Neal Michael } \\
3010 \text { Ferry Street } \\
\text { Albany, OR } 97321\end{array}$ & $\mathbf{Y}$ & $\mathbf{N}$ & G & - & \\
\hline $\begin{array}{l}\text { Litron Guidance \& Control Systems Division } \\
\text { Attn: Eldon J. Luick } \\
1001 \text { Redwood Highway Spur } \\
\text { Grants Pass, OR } 97926\end{array}$ & $Y$ & $\mathbf{N}$ & 1 & $:$ & \\
\hline $\begin{array}{l}\text { MeKenzie-Willamette Hospital } \\
\text { Attn: Leslie Dos Reis, M.D. } \\
1460 \text { C Street } \\
\text { SprIngllald, OR } 97477\end{array}$ & $Y$ & $\mathbf{N}$ & M & - & \\
\hline
\end{tabular}




\begin{tabular}{|c|c|c|c|c|c|}
\hline & Ouest & ionnairs & & & \\
\hline Licensen Name and Address & $\frac{8}{8}$ & : $\frac{3}{8}$ & $\frac{\pi}{8}$ & $\frac{5}{\bar{E}}$ & Comments \\
\hline $\begin{array}{l}\text { Medford Corporation } \\
\text { Attn: Matthew D. Reilly } \\
\text { P.O. Box } 550 \\
\text { Medford, OR } 97501\end{array}$ & $\mathbf{Y}$ & 1 & 1 & $\mathbf{N}$ & No waste. \\
\hline $\begin{array}{l}\text { Menasha Corp.-Paperboard Div. } \\
\text { Arrn: T. F. Williscroft } \\
\text { Jordan.Point } \\
\text { North Bend, OR } 97459\end{array}$ & $\mathbf{Y}$ & $\mathbf{N}$ & 1 & - & \\
\hline $\begin{array}{l}\text { Mercy Medical Center, Inc. } \\
\text { Attn: Sister Jacquette Taylor } \\
2700 \text { Steward Parkway } \\
\text { Roseburg, OR } 97470\end{array}$ & $\mathbf{Y}$ & $\mathbf{N}$ & $M$ & - & \\
\hline $\begin{array}{l}\text { Merropolitan Hospitals } \\
\text { Attil: Ruger Larson } \\
2800 \text { Vancouver Avenue, Suite } 235 \\
\text { Portland. OR } 97227\end{array}$ & $Y$ & 1 & $\mathbf{M}$ & $Y$ & \\
\hline $\begin{array}{l}\text { Mogul Corporation } \\
\text { Attn: Lee Henry } \\
2852 \text { N.W. } 31 \text { ist Avenue } \\
\text { Portland, OR } 97210\end{array}$ & $\mathbf{Y}$ & $\mathbf{N}$ & 1 & - & . \\
\hline $\begin{array}{l}\text { Mulinomah County, Div. of Operations \& Manntenance } \\
\text { Atin: Tor Lyshaug } \\
9659 \text { N.E Hancock Drive } \\
\text { Portland, OR } 97220\end{array}$ & $\mathbf{Y}$ & 1 & G & $\mathbf{N}$ & . \\
\hline $\begin{array}{l}\text { National Mechanical Data Company } \\
\text { Attn: John Restango } \\
\text { 80: S. W. Ulimbus Aver ILe } \\
\text { Beaverton, OR } 97005\end{array}$ & $\mathbf{N}$ & $\mathbf{N}$ & 1 & $\cdot$ & Na suah addreso. \\
\hline $\begin{array}{l}\text { Neptune Micofloc, Inc. } \\
\text { Attn: Robert M. Guptill } \\
1965 \text { Airport Rasd } \\
\text { Corvallis, OR } 97330\end{array}$ & $\mathbf{Y}$ & 1 & 1 & $\mathbf{N}$ & \\
\hline $\begin{array}{l}\text { Nerco, Inc. } \\
\text { Attn: Philip Bailie } \\
\text { S29 5. W. Third Avenue } \\
\text { Portland, OR } 97204\end{array}$ & $\mathbf{Y}$ & 1 & 1 & $\mathbf{N}$ & . \\
\hline $\begin{array}{l}\text { G. R. Nicholson, M.D. } \\
\text { 2865 Daggett Street } \\
\text { Klamath Falls, OR } 97601\end{array}$ & $\mathbf{Y}$ & $N$ & $M$ & $\cdot$ & . \\
\hline $\begin{array}{l}\text { North Pacific Products Company } \\
\text { Atrn: C. H. Cleveland } \\
\text { North Century Drive } \\
\text { Bend, OR } 97701 \\
\end{array}$ & $\mathbf{Y}$ & 1 & 1 & $\mathbf{N}$ & No waste. \\
\hline $\begin{array}{l}\text { Nur liwwest Narurai Gas Company } \\
\text { Arn: W. T. Amies } \\
123 \text { N.W. Flanders Streer } \\
\text { Portland, OR } 97209\end{array}$ & $\mathbf{Y}$ & 1 & $I$ & $\mathbf{N}$ & \\
\hline $\begin{array}{l}\text { Northwest Testing Labs } \\
\text { Atrn: Paul lrish } \\
4115 \text { N. Mississippi } \\
\text { Portland, OR } 97217\end{array}$ & $\mathbf{Y}$ & $\mathbf{N}$ & $I$ & - & \\
\hline $\begin{array}{l}\text { Oregon Graduate Center } \\
\text { Artn: J. Richard Kerr } \\
19600 \text { N.W. Waiker Road } \\
\text { Beaverton, OR } 97005\end{array}$ & $Y$ & 1 & $\mathbf{E}$ & $\mathbf{Y}$ & \\
\hline
\end{tabular}




\begin{tabular}{|c|c|c|c|c|c|}
\hline \multirow[b]{2}{*}{ Licenses Name and Address } & \multicolumn{2}{|c|}{ Qurestionnaire } & \multirow{2}{*}{$\begin{array}{l}\frac{z}{\bar{Z}} \\
\frac{\mathbf{z}}{4} \\
\overline{0} \\
\frac{8}{2}\end{array}$} & \multirow{2}{*}{ 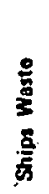 } & \multirow[b]{2}{*}{ Comments } \\
\hline & $\stackrel{8}{\bar{g}}$ & $\frac{\mathrm{g}}{\mathrm{g}}$ & & & \\
\hline $\begin{array}{l}\text { Oregon lnstitute Of Technology. } \\
\text { Attn: James Cerhardt } \\
\text { Orerech Branch Post Office } \\
\text { Klamath Falls, OR } 97601\end{array}$ & $\mathbf{Y}$ & 1 & E & $\mathbf{N}$ & $\begin{array}{l}\text { Have } H-3 \text { zargers and some } \\
\text { sources they would like to get } \\
\text { rid of - method not specified. }\end{array}$ \\
\hline $\begin{array}{l}\text { Oregon Museum of Science-Industry } \\
\text { Atrn: Clint Gruber } \\
4015 \text { S. W. Canyon Road } \\
\text { Portland, OR } 97221\end{array}$ & $\mathbf{Y}$ & $N$ & E & - & . \\
\hline $\begin{array}{l}\text { Oregon Portland Cemem Company } \\
\text { Attn: Alan Howk } \\
\text { P.O. Box } 189 \\
\text { Lake Oswego, OR } 97034\end{array}$ & $\mathbf{Y}$ & 1 & 1 & N & - \\
\hline $\begin{array}{l}\text { Oregon Potato } \\
\text { Attn: Doug Beerman } \\
\text { P.O. Box 169 } \\
\text { Boardman, OR } 97818\end{array}$ & $\mathbf{Y}$ & $\mathbf{N}$ & I & - & \\
\hline $\begin{array}{l}\text { Oregon Regional Primate Research Center } \\
\text { Attn: C. H. Beatty, Ph.D. } \\
\text { SOS N.W. } 185 \text { th Avenue } \\
\text { Bea verton, OR } 97005\end{array}$ & $\mathbf{Y}$ & 1 & $M$ & $\mathbf{Y}$ & . \\
\hline $\begin{array}{l}\text { Oregon State Department of Agriculture } \\
\text { Amn: H. M. Wehr, Lab Administrator } \\
635 \text { Capitol Street, N.E } \\
\text { Salem, OR } 97310\end{array}$ & $\mathbf{Y}$ & 1 & G & $\mathbf{N}$ & . \\
\hline $\begin{array}{l}\text { Oregon State Dept. of Env. Qual. } \\
\text { Atrn: Warren Westgarth } \\
\text { P.O. Box } 1760 \\
\text { Portiand, OR } 97207\end{array}$ & $\mathbf{Y}$ & $N$ & G & - & 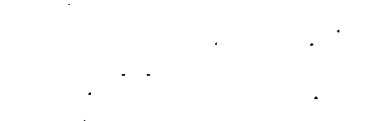 \\
\hline $\begin{array}{l}\text { Oregon State Highway Division } \\
\text { Atrn: M.D. Glenn } \\
\text { Transportation Building } \\
\text { Salem, OR } 97310\end{array}$ & $\mathbf{Y}$ & $\mathbf{N}$ & C & 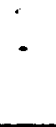 & . \\
\hline $\begin{array}{l}\text { Oregon State University } \\
\text { Attn: Chairman Rad Safery } \\
\text { Comwaldo Hall Room } 120 \\
\text { Corvallis, OR } 9733 !\end{array}$ & $\mathbf{Y}$ & 1 & $\mathbf{E}$ & $\mathbf{Y}$ & \\
\hline $\begin{array}{l}\text { Oregon Steel Mills } \\
\text { Attn: Wesley A. Tevik } \\
\text { P.O. Box } 2760 \\
\text { Portland, OR } 97208\end{array}$ & $\mathbf{Y}$ & $\mathbf{N}$ & 1. & - & , \\
\hline $\begin{array}{l}\text { Oregon Workers' Comp. Dept. } \\
\text { Attn: Martin Jurgenson } \\
204 \text { Labor \& Industries Bivd. } \\
\text { Salem, OR } 97310\end{array}$ & $\mathbf{Y}$ & $\mathbf{N}$ & $G$ & $\cdot$ & . \\
\hline $\begin{array}{l}\text { OSHD-Radiation Cortrol Section } \\
\text { Attn: M.W. Parrott } \\
140 \text { S. W. Sth Avenue } \\
\text { Portland, OR } 97201\end{array}$ & $Y$ & $\mathbf{N}$ & $G$ &. & . \\
\hline $\begin{array}{l}\text { Owens-lllinois, Inc. } \\
\text { Attn: K. H. Lemke } \\
\text { P.O. Box } 20067 \\
\text { Porrland, OR } 97220\end{array}$ & $\mathbf{Y}$ & $\mathbf{N}$ & 1 & - & - \\
\hline $\begin{array}{l}\text { Pacific Medical Imaging } \\
\text { Attnt. Edgar E. Clark, M.D. } \\
\text { Tillamook County General Hospital } \\
\text { Tillameok, OR } 9714 \text { ! }\end{array}$ & $\mathbf{Y}$ & 1 & $M$ & $\mathbf{N}$ & No waste. \\
\hline
\end{tabular}




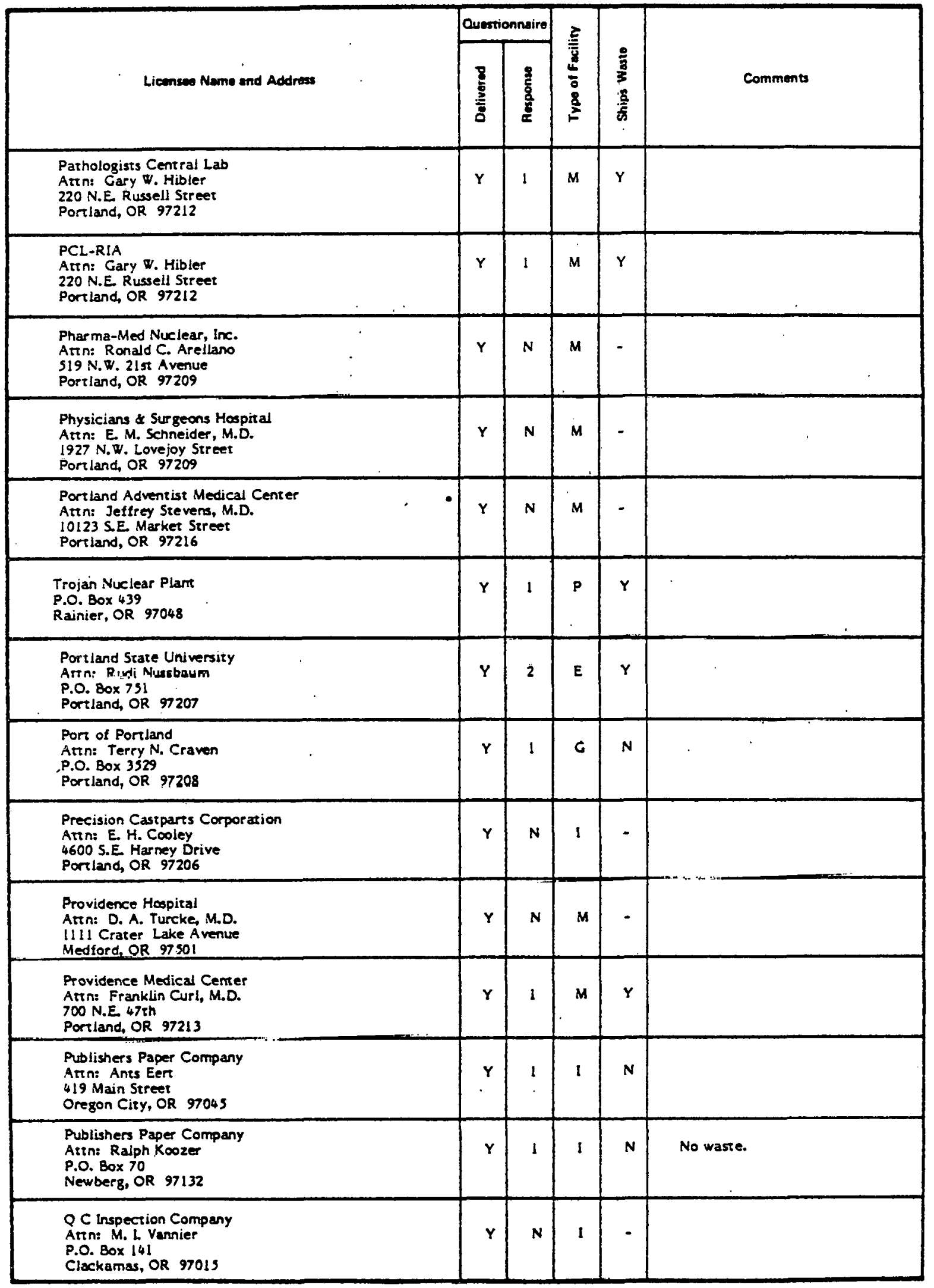




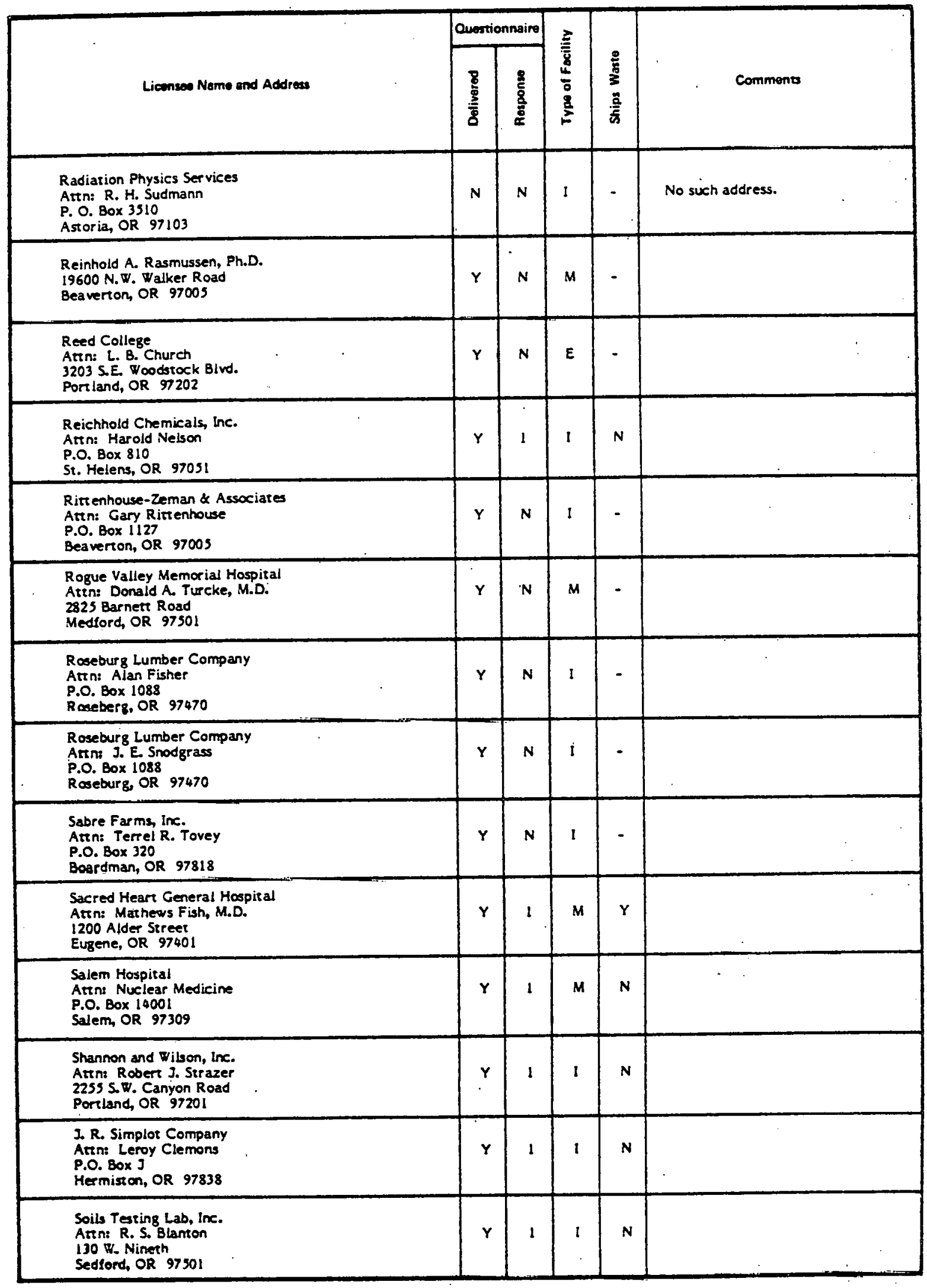




\begin{tabular}{|c|c|c|c|c|c|}
\hline \multirow[b]{2}{*}{ Licomen Name end Address } & \multicolumn{2}{|c|}{ Questionnaire } & \multirow{2}{*}{ 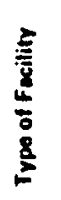 } & \multirow{2}{*}{ 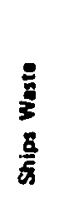 } & \multirow[b]{2}{*}{ Comments } \\
\hline & $\begin{array}{l}\frac{8}{8} \\
\frac{3}{8}\end{array}$ & 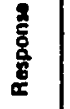 & & & \\
\hline $\begin{array}{l}\text { Sourthern Oregon General Hospital } \\
\text { Attn: R. S. Ballantyne, M.D. } \\
\text { 1505 N.W. Washington Blvd. } \\
\text { Grants Pass, OR } 97526\end{array}$ & $\mathbf{Y}$ & $\mathbf{N}$ & $\mathbf{M}$ & - & \\
\hline $\begin{array}{l}\text { Sourhern Oregon State College } \\
\text { Atrn: J. G. Couch } \\
1250 \text { Siskiyou Blvd. } \\
\text { Ashland, OR } 97520\end{array}$ & $\mathbf{Y}$ & $\mathbf{N}$ & $E$ & - & \\
\hline $\begin{array}{l}\text { Sr. Anthony Hospital } \\
\text { Arn: Sr. Helen A. Gaidos } \\
1601 \text { S. E. Court Avenue } \\
\text { Pendieton, OR } 97801\end{array}$ & $\gamma$ & 1 & $M$ & $\mathbf{N}$ & \\
\hline $\begin{array}{l}\text { St. Charies Medical Center } \\
\text { Attn: T. J. Muller, M.D. } \\
2500 \text { N.E Neff Road } \\
\text { Bend, OR } 97701\end{array}$ & $\mathbf{Y}$ & $\mathbf{N}$ & $M$ & - & \\
\hline $\begin{array}{l}\text { St. Vincent Hospital \& Medical Center } \\
\text { Arn: Eugene Jackson, M.D. } \\
9205 \text { S. W. Barnes Road } \\
\text { Portland, OR } 97225\end{array}$ & $\gamma$ & 1 & $M$ & $N$ & \\
\hline $\begin{array}{l}\text { State of Oregon Military Department } \\
\text { Attn: Maj. Cen. Richard Millet } \\
\text { 21 s0 Fairgrounds Road, N.E. } \\
\text { Sajem, OR } 97303\end{array}$ & $Y$ & $N$ & $G$ & - & \\
\hline $\begin{array}{l}\text { Tektronix, Inc. } \\
\text { Artn: } r=\text {, Shink } \\
\text { P.O. Box } 500 \\
\text { Beaverton, OR } 97077\end{array}$ & $Y$ & $\mathbf{N}$ & 1 & - & \\
\hline $\begin{array}{l}\text { The Dallas General Hospital } \\
\text { Attn: Gary L Rood } \\
\text { Irth \& Nevada } \\
\text { Dallas, OR } 97058\end{array}$ & $Y$ & $\mathbf{N}$ & $\mathbf{M}$ & - & \\
\hline $\begin{array}{l}\text { The Hanna Mining Ca. -Nickel } \\
\text { Attn: E J. Soderberg } \\
\text { P.O. Box } 89 \\
\text { Riddle, OR } 97469\end{array}$ & $Y$ & $N$ & I & $\cdot$ & \\
\hline $\begin{array}{l}\text { Tuality Community Hospital } \\
\text { Attn: George J. Vemes, M.D. } \\
\text { P.O. Box } 241 \\
\text { Hilsboro, OR } 97123\end{array}$ & $\mathbf{Y}$ & 1 & $\mathbf{M}$ & $\mathbf{N}$ & \\
\hline $\begin{array}{l}\text { Umpqua Research Company } \\
\text { Atrn: Gerald V. Colombo } \\
\text { P.O. Box } 791 \\
\text { Myrtle Creek, OR } 97457\end{array}$ & $\mathbf{Y}$ & $\mathbf{N}$ & 1 & - & \\
\hline $\begin{array}{l}\text { Unified Sewerage Agency } \\
\text { Atrn: Gary Krahmer } \\
\text { iso N. Ist } \\
\text { Hillsboro, OR } 97123\end{array}$ & $\mathbf{Y}$ & 1 & G & $\mathbf{N}$ & \\
\hline $\begin{array}{l}\text { University of Oregon } \\
\text { Atr: Gordon Goles, Ph.D. } \\
\text { P.O. Box } 3075 \\
\text { Eugene, OR } 97403\end{array}$ & $\mathbf{Y}$ & $\mathbf{N}$ & $\mathbf{E}$ & - & \\
\hline $\begin{array}{l}\text { University of Portland } \\
\text { Atrns Paul E Wack } \\
\text { s000 N. Willametre Blvd } \\
\text { Portland, OR } 97203\end{array}$ & $\mathbf{Y}$ & 1 & E & $\mathbf{N}$ & No waste. \\
\hline
\end{tabular}




\begin{tabular}{|c|c|c|c|c|c|}
\hline \multirow[b]{2}{*}{ Lieenses Neme and Addrus } & \multicolumn{2}{|c|}{ Questionnaire } & \multirow{2}{*}{ 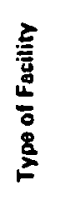 } & \multirow[b]{2}{*}{$\begin{array}{l}\frac{9}{3} \\
\frac{3}{3} \\
\frac{3}{5}\end{array}$} & \multirow[b]{2}{*}{ Comments } \\
\hline & $\frac{8}{8}$ & 茞. & & & \\
\hline $\begin{array}{l}\text { UOHSC School of Dentistry } \\
\text { Attn: Dean C Gatewood } \\
611 \text { S. W. Campus Drive } \\
\text { Portland, OR } 97201\end{array}$ & $\mathbf{Y}$ & 1 & $\mathbf{E}$ & $Y$ & . \\
\hline $\begin{array}{l}\text { Washington County Depr. Public Works } \\
\text { Atrn: William Wise } \\
\text { 150 N. First } \\
\text { Hillsboro, OR } 97123\end{array}$ & $Y$ & $\mathbf{N}$ & G & - & ' \\
\hline $\begin{array}{l}\text { Washington County School District } \\
\text { Atrn: E C Springer } \\
\text { P.O. Box } 200 \\
\text { Beaverton, OR } 97005\end{array}$ & Y. & 1 & $\boldsymbol{E}$ & $\mathbf{N}$ & \\
\hline $\begin{array}{l}\text { Warer Analysis \& Consulting } \\
\text { Attn: Jeff Siegel } \\
304 \text { Blair Blvd } \\
\text { Eugene, OR } 97401\end{array}$ & $Y$ & $\mathbf{N}$ & 1 & - & $\cdot$ \\
\hline $\begin{array}{l}\text { Western Kraft Corporation } \\
\text { Attn: R. 8. Campbell } \\
\text { P.O. Box } 339 \\
\text { Albany, OR } 97321\end{array}$ & $\mathbf{Y}$ & $\mathbf{N}$ & 1 & - & \\
\hline $\begin{array}{l}\text { Western Professional, Inc. } \\
\text { Atrn: L J. Chamberlain } \\
649 \text { gth Street, N. } W . \\
\text { Beaverion, OR } 97005\end{array}$ & $\mathbf{Y}$ & 1 & I & $\mathbf{N}$ & \\
\hline $\begin{array}{l}\text { Weyerhaeuser Company } \\
\text { Attn: W. R. Cole } \\
\text { P.O: Box } 389 \\
\text { Noŕth Bend. OR } 97459\end{array}$ & $Y$ & $\mathbf{N}$ & $i$ & - & \\
\hline $\begin{array}{l}\text { Weyerhaeuser Company } \\
\text { Atrn: E. G. Gjertsen } \\
\text { P.O. Box } 9 \\
\text { Klamath Falls, OR } 97601\end{array}$ & $Y$ & 1 & 1 & $\mathbf{N}$ & \\
\hline $\begin{array}{l}\text { Weyerhaeuser Company } \\
\text { Attn: Don Kaster } \\
\text { P.O. Box } 275 \\
\text { Springfield, OR } 97477\end{array}$ & $\mathbf{Y}$ & 1 & I & $\mathbf{Y}$ & . \\
\hline $\begin{array}{l}\text { Willamette Falls Comm. Hospit al } \\
\text { Attn: H. E Hollowell, Admin. } \\
\text { Ith \& Division } \\
\text { Oregon City, OR } 97045\end{array}$ & $\mathbf{Y}$ & $\mathbf{N}$ & $\mathbf{M}$ & - & \\
\hline $\begin{array}{l}\text { Willamerte-West ern Corporation } \\
\text { Atrn: Robert L Pyritz } \\
\text { P.O. Box 03190 } \\
\text { Portland. OR } 97203\end{array}$ & $\mathbf{Y}$ & 1 & $I$ & $\mathbf{N}$ & No waste. \\
\hline $\begin{array}{l}\text { William L. Wales \& Assoc. } \\
1740 \text { Austin Street } \\
\text { Klamath Falls, OR } 97601\end{array}$ & $\mathbf{Y}$ & 1 & $I$ & $\mathbf{N}$ & \\
\hline $\begin{array}{l}\text { Woodex, Inc. } \\
\text { Attn: Norm Norton } \\
34401 \text { Lake Creek Drive } \\
\text { Brownsville, OR } 97327\end{array}$ & $\mathbf{Y}$ & 1 & I & $\mathbf{N}$ & \\
\hline $\begin{array}{l}\text { Woodland Park Hospital } \\
\text { Atrn: R. F. Friedman, M.D. } \\
10300 \text { N.E Hancock Street } \\
\text { Portland, OR } 97220\end{array}$ & $\mathbf{Y}$ & 1 & $\mathbf{M}$ & $\mathbf{N}$ & \\
\hline
\end{tabular}




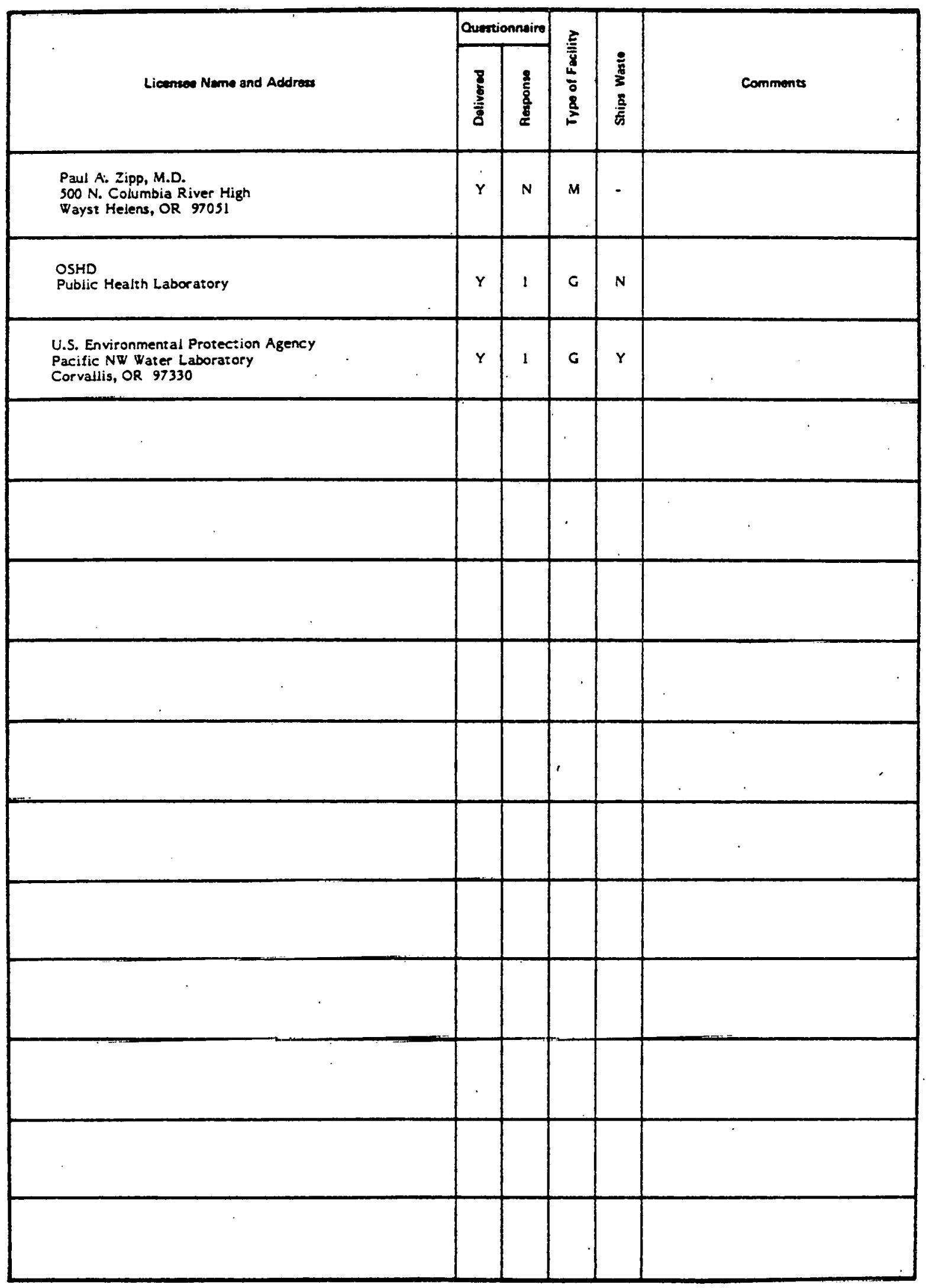




\section{APPENDIX B}

STATE LAWS AND REGULATIONS APPLYING TO RADIOACTIVE WASTE MANAGEMENT IN OREGON 
c.

$$
\begin{aligned}
& \text { C-Engrosend }
\end{aligned}
$$

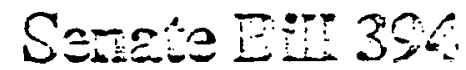

Ordered by the House May 7

(Including Amendments by Senate February 26: by Senate. by rules suspension, February 26 and by House May 7)

Sponsored by Senator HALLOCK

\section{SUMEMARY}

The following summary is not prepared by the sponsors of the measure and is not a part of the body' thereof subject to consideration by the Legislative Assembly. It is an editor's brief statement of the essential features of the measure.

Redefines "radioactive waste[.]" and "waste disposal faciltty." Requires Health Division to [cause a] contract for an independent study to be made of public hesith hazards of raoioastive w'zte and report $w$ next Legislative Assembly. Prohibits establishment, operation or licensing of any radiasctive waste disposal facility. Provides that, prior to July 1, 1981, maintenance of radioactive waste deposited prior to Niarch 1, 1979, shall not constitute operation of a waste dispocal facility. Specifies that site certivicate for waste disposal facilities for uranium mill tailings, mill wastes and mill by-praduct mateia shall not be issusd uniess certan finclings are made. Requires those persons maintaining ralioective wastes depesited prior to March 1, 1979, to pay a proportionate share of the costs necescary for Health Division to carry out the stidy required by Act. Requires persons desiring to construct or operate a uraium mill or uranium mill tailings disposal facility to file a site certificote application with Energy Faclity Siting Council. Permits cowncil to adopt rules relating to urarium mill and tzilings disposal facilicies. Permits council to enter into certain agreements with Secretary of Energy. [each generator of radioaciive Hoste to pay a proportional share of the cost of the Health Division study out of license fees. Protibits division from granting a license for radioactive waste disposal facility unless specified findings are made.]

Declares emergency, effective on passage.

\section{A BILL FOR AN ACT}

Relating to waste disposal; creating new provisions; amending ORS 469.300, 469.375 and 469.525 ; and declaring an emergency.

Be It Enacted by the People of the State of Oregon:

Section 1. ORS 469.300 is amended to read:

469.300. As used in ORS 469.300 to 469.570 and 469.992 , uniess the context requires otherwise:

(1) "Applicant" means any person who makes application for a site certificate in the manner provided in ORS 469.300 to 469.570 and 469.992.

(2) "Application" means a request for approval of a particular site or sites for the construction and operacion of an energy facility or the construction and operation of an additional energy facility upon a site for which a certificate has already been issued, flled in accordance with the procedures established pursuant to ORS 469.300 to 469.570 and 469.992

(3) "Associated transmission lines" means new transmission lines constructed to connect a thermal power plant to the first point of junction of such transmission line or lines with either a power distribution system or an interconnected primary transmission system or both or to the Northwest Power Grid.

(4) "Combustion turbine power plant" means a thermal power plant consisting of one or more fuel-fired combustion turbines and any associated waste heat combined cycle generators.

(5) "Construction" means onsite work and construction, the cost of which exceeds $\$ 250,000$, excluding exploratory work.

(6) "Council" means the Energy Facility Siting Council established under ORS 469.450.

NOTE: Natter in bold lace in an amended section is new; matter [italic and bracketed is existing law to be omitzed; complete new sections begin with SECTION. 
$\because \because \div \div \div: \because:$

121

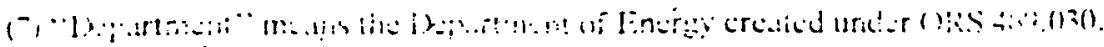

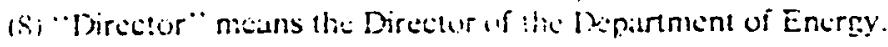

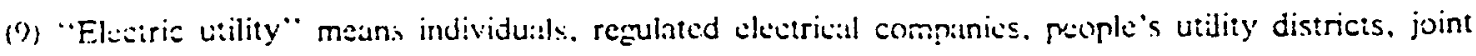
opirating as:ncies, electric cooperatives. municipalities or any combiration thercof. engined in or juthorized to engage in the business of gunerating. Uransmitting or distributing electric energy. "Electric utility" includes any person or public agency generating electric energy from an energy facility for its own consumption.

(10) "Energy faciiity" means any of the following:

(a) An electric power generating plant with a nominal electric generating capacity of more than 25,000 kilowatts, including but not limited to thermal power, hydropower, geothermal power, or combustion turbine power plant.

(b) A nuclear installation as defined in this section.

(c) A high voltage transmission line of more than 10 miles in length with a capacity in excess of 230,000 volts, to be constructed in more than one political subdivision in this state: but excluding lines proposed for consiruction entirely within 500 feet of an e.jisting conidor occupied by high voltage transmission lines with a cipacity in excess of 230,000 volts.

(d) A solar cellecting facility using mere than 100 acres of land, or providing more than 25,000, kilowatts of poirer.

(e) A pipeline that is:

(A) Six inches or greater in diameter, and five miles or longer in length, used for the transportation of crude petroleum or a derivative thereof, liquified natural gas, a geothermal energy form or other fossil energy resource.

(B) Sixteen inches or greater in diameter, and five miles or longer in length, used for the transportation of natural or synthetic gas.

(11) "Nuclear installation" means any power reactor; nuclear fuel fabricutiun plant; nuelcar fuel reprocessing plant; waste disposal facility for radioactive waste; and any facility handling that quantity of fissionable materials sufficient to form a critical mass. "Nuclear installation" does not include any such facilities which are part of a thermal power plant.

(12) "Person" means an individual, partnership, joint venture, private or public corporation, association. firm, public service company, political subdivision, municipal corporation, government agency, people's utility district, or any other entity, public or private. however organized.

[(13) "Radioactive waste" means discarded or unwanted radioactive material, including mined or refined naturally occurring or accelerator produced isotopes and by-product material, source material or special nuclear material as defined by ORS 453.605.]

(13) (a) "Radioactive waste" means radioactive material which is disearded, unwanted or has no present lawful economic use, including mined or retined naturally occurring isotopes, sccelerator produced isotopes and by-product material, source material or special nuclear material as those terms are defined in ORS 453.605 . The te:m does not indude those radioactive materials identified in OAR 345-50-020, 345-50-025 and 345-50-035, ar: $: 5$ ta by the council on December 12, 1978, as presenting no significant danger to the public health ard safety.

(b) Notnsthstanding paragraph (a) of this subsection, "radioactive warte" dces not include uranivin mine overburden or uranit:m mill tallings, mill wastes or mill by-product materials as those terms are defined in Title 42, United States Code, section 2014, on the effective date of this 1979 Act. 
(14) "Related or supporting facilities" means any structure adjacent to and associated with an energy faclity, including associated transmission lines, reservoirs, intake structures, road and rail access, pipelines, barge basins, office or public buidings, and commercial and industrial structures proposed to be built in connection with the energy facility.

(15) "Site" means any proposed location of an energy facility and related or supporting facilities.

(10) "Site certificate" means the binding agreement between the State of Oregon and the applicant, authorizing the applicant to construct and operate an energy facility on an approved site, incorporating all conditions imposed by the state on the applicant and all warranties given by the applicant to the state.

(17) "Themal power plant" means an electrical or any other facility using any source of thermal energy with a nominal electric generating capacity of more than 25,000 kilowiatts, for generation and distribution of electricity, and associated transmission lines, including but not limited to a nuclear-fueled, geothermal-fueled or fossi-fueled power plant, bu: not including a portable power plant the principal use of which is to supply power in emergencies.

(18) "Transportation" 'means the transport within the borders of the State of Oregon of radioactive material destined for or cerived from any thermal power plant or nuclear installation, or the delivery of such material to a carrier for transportation.

(19) "Utility" includes:

(a) An individual, a regulated electrical company, a people's utility district, a joint operating agency, an electric cooperative, municjpality or any combination thereof, engaged in or authorized to engage in the business of generating, transmitting or distributing elẹtric energy;

(b) A person or public agency generating electric energy from an energy facility for its own consumption; and

(c) A person engaged in this state in the transmission or distribution of natural or synthetic gas.

(20) "Waste disposal facility" means a geographical site in or upon which radioactive waste is held or placed [for more than seven days] but does. not include a site at which [the] radioactive waste [was] used or generated pursuant to a license granted under ORS 453.635 [or] is stored temporarily, a site of a thermal power plant used for the temporary storage of radioactive [material] waste from that plant for which a site certificate has been issued pursuant to this chapter or a site used for temporary storage of radioactive waste from a reactor operated by a college, university or graduate center for research purposes and not connected to the Northwest Power Grid.

Section 2. ORS 469.525 is amended to read:

469.525. (1) Notwithstanding any other provision of this chapter, no waste disposal facility for any radioactive [materia] waste shall be established, operated or licensed within this state.

(2) Prior to July 1, 1981, maintenance of radioactive waste deposited in Oregon prior to March 1, 1979, shall not constitute operation of a waste disposal tacility.

Section 3. ORS 469.375 is amended to read:

469.375. The council shall not issue a site certificate for a waste disposal facility for uranium mill tailings, mill wastes and mill by-product muterial or for radioactive waste or mdioactively contaminated containers or receptacles used in the transpurtation, storage, use or application of radioactive material, unless, accompanying its decision, it finds: 
(1) The site is suitable for disposal of such wastes, and the amount thereof, intended for disposal at the site;

(2) It is recessary to dispose of such wastes, and the amount thereof, at the site in Oregon to protect the environment, and the health, safety and welfare of the people of the state from such wastes;

(3) There is no available, economically feasible altemative for disposal of such wastes, and the amount thereof, inside or outside of the state;

(4) The disposal of such wastes, and the amount thereof, at the site will be compatible with the regulatory programs of the Federal Government for disposal of such wastes; and

(5) The disposal of such wastes, and the amount thereof, at the site will be coordinated with the regulatory prograns of adjacent states for disposal of such wastes.

SECTION 4. (1) The Health Division shall contract for an independent study of public health hazards associated with storage of the waste described in subsection (13) of ORS 469.300 in this state. The division shall determine:

(a) Whether and to what extent such waste presents a hazard to the health and safety of the people of the State of Oregon; and

(b) What methods are available for disposal of such waste and the relative effectiveness, safety and cost of those methods.

(2) The Health Division shall report its findings to the Sixty-first Legislative Assembly.

SECTION 5. In addition to any other fees required by law, any person who, but for the provisions of subsection (2) of ORS 469.525, would be in violation of subsection (1) of ORS 469.525 shall pay to the Health Division, on or after July 1, 1979, a proportionate share of an assessment of all such persons sufficient to reimburse the division for the cost of the study required by section 4 of this Act.

SECTION 6. Sections 7 to 9 of this Act are added to and made a part of ORS 469.300 to 459.570 .

SECIION 7. (1) Any person desiring to construct or operate a uranium mill or uraniun riil taijir:js disposal facility after the effective date of this 1979 Act, shall file with the Energy Facility Siting Cotrcil a sits certificate application.

(2) The Energy Facility Siting Council shall review an application for a site cerrificate under this section using the procedure prescribed in ORS $469.350,469.360,469.370,469.375,469.380,469.390$ ard 469.400 , for energy facilities. The council is authorized to assess fees in accordance with ORS 469.420 in connection with site cerificates applied for or issued uncer this section.

SECIION 8. The Energy Facility Siting Council shall adopt rules governing the location, construction and operation of uranium mills and uranium mill tailings disposal facilities and the treatment, storage and disposal of uranium mine overburden for the protection of the public health and safety and the environment.

SECTION 9. (1) Notwithstanding the authority of the Health Division pursuant to ORS 453.605 to 453.745 to regulate radiation sources or the requirements of ORS 469.525 , the Energy Facility Siting Council may enter into and carry out cooperative agreements with the Secretary of Energy pursuant to Title I and the Nuclear R.gitatory Commission pursuant to Title $\Pi$ of the Uranium Mill Tailings Radiution Control Act of 1973, Putlic

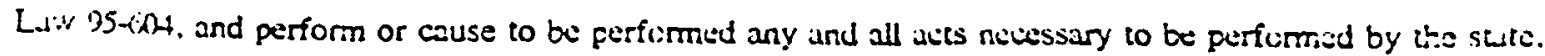

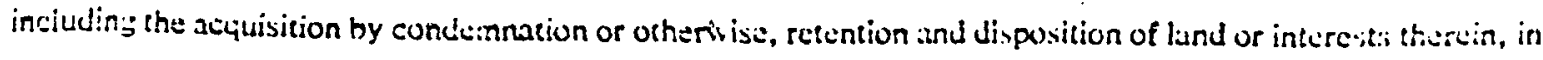

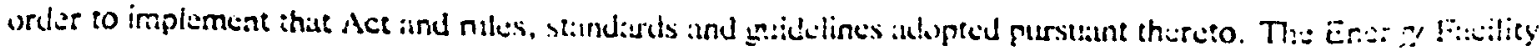


1 Siting Council may adopt, amend or repeal rules in accordance with ORS 183.310 to 183.500 and may receive : and disturse furds in connection with the implementation ard administration of this section.

(2) The Govemor may do any ard all thirgo necessary to implement the requirements of the federal Act 4 referred to in subsection (1) of this section.

5 SECTION 10. This Act being necessary for the immediate preservation of the public peace, health and 6 safety, an emergency is declared to exist, and this Act takes effect on its passage. 


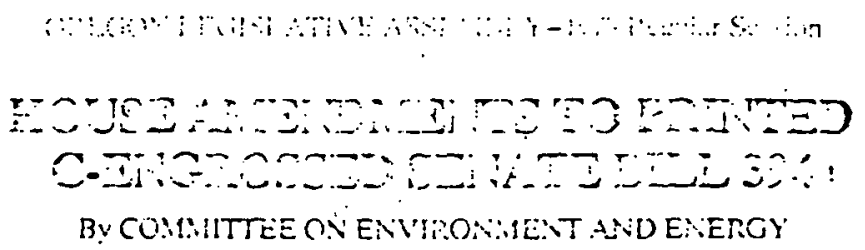

May 24

\section{Amended Sumniary}

Redefines "radioactive waste" and "waste disposal facility." Requires Health Division to contract for an independent study to be made of public health hazards of radioactive waste and report to next Legislative Assembly. Prohibits establishment, operation or licensing of any radioactive waste disposal facility. Provides that, prior to [ July $\cap$ December 31, 1981, maintenance of radioactive waste deposited prior to March 1, 1979 , shall not constitute operation of a waste disposal facility. Provides that maintenence of ra:santive cool asi a: therm:al power plant site does not constitute operaticn of u aste oibocal fecility if spsciitid coridica mot. Sprecifies that site cerificate for waste disposal faculities for urinium mill tailings, mill wasies ard mill by-piculuct material shall not be issued unless certain finoings are made. Reguires those persons mainiaining ridioactive wastes deposited prior to March 1,1979 , to pay a picporticuate shice of tice costs necessary for Health Division to carry out the study required by Act. Requires persons desi-ing to consuruct or operate a uranium mil' o: uranium mill tailings disposal facility to file a siie certificate application with Ener? Facility Sitine Council. Pernits council to adopt rules re!auirg to uranium mill and tailings dispcsal facilities. Pemits councul to enter into certain ayseements with Secretary of Energy.

Declajes emergency, effective on passage.

On paze 3 of the piinted C-engossed bill. line 34, de!ete "July 1 " and inser "December 31 ". $\therefore$ fíter line 35 , insert:

(3) Misinienasce of radioactive coal ast at the site of a thermal power plant for which a site cerificate has been issued pursuant to this chapter shall not constitute operation of a waste disposal facility so long as such coal ash is maintained in accordance with the terms of the site certificate as amended from time to time as necessary to protect the public health and safety." 


\section{DIVISION 50}

\section{RADIOACTIVE WASTE MATERIALS}

\author{
Dipasal Sites for Rodionctive Materials \\ 345-50-00S DNEC 3, . 5-19-72. \\ ef. $6-1.72$; \\ Repealed by EFSC 9-1978, \\ l. 12-28-78, ef. 3-1-79]
}

Dtopoend Probibited

345-50-006 Effective May 1, 1979, except as provided berein, no discanded or unwanted radioactive material may be beid or placed for more than seven days at any geographical site in Oregon except the site at which the radioactive material was used or senerated pursuant wo a license under ORS 453.635 or a site of a thermal power plant used for the temporary storage of radionctive material from that plant for which a site certificate has been issued by the Eneroy Facility Siting Council.

Sent. Auth.: ORS Ch. 469

Hix: EFSC 21978, t. 12-28-78, ef. 3-1-79; EFSC 1-1979(Teonp). 1. det. $3-5-79$

Purpose and Applicablity

345.50-010 Since virmally all materials contain some measure of radioactivity, it is the purpose of these rules to identify those materials which present such small bealth hazards that they are exempt trom the provisions of ORS 469.525 (1977 Replacement Part) is incorporated in rule 345-50-006 and may be disposed of within the state.

Sthe Auth: ORS Ch. 460

Hin: EFSC $9-1978,1.12-28-78$, \&. 3-1.79

Lixempt Quantities

345-50-020 Materials are exempt from provisions of ORS 469.525 provided that such materials contain radioactive material in individual quantities none of which exceeds that applicable quantity see forth in Table 2 and provided that the number of individual quantities does not exceed 10.

Stat. Auth.: ORS Ch. 160

His: EFSC 2-1978, 1. 12-28-78, ef. 3-1-79

Exempt Concentrations

345-50-025 Materials are exempt from the provisions of ORS 469.525 provided that such materiais contain radinactive materials in concentritions not in excess of those of Table 1.

Str. Auth: ORS Ch. $460^{\circ}$

Hir: EFSC 2-1978, 1. 12-28-78, \&. 3-1-79

Specific Exempdons

345.50-030 In addition to the exemptions under rules 345-50-020 and 345-50-025, the following materials are exempt from the provisions of rule 345-50-006 (or ORS 469.525):

(1) Radioactive muterial which has beed incorporated into - consumer product manufactrred under a license issued by the Nuclear Regulatory Commission, or an Agreement State and for which the arency licensing such manufacturer has determined that the possession, use, transfer. and disposal of such consumer product by all persons is exempt from regulatory requirements.

(2) Radium-beariag materials containing less than 5 picocuries of radium-226 per gram of solid, regardless of quantity.

(3) Radium-bearing material containing a total radium-226 activity of less than 10 microcuries, regardless of concentration.

(4) Thorium-bearing materials containing less than 20 picocuries of radium-228 per gram of solid, providing that the ratium-228 is preseat with the parent thorium-232, regardless of quantity.

(5) Thorium-bearing materials containing a total radium228 activity of less than 100 microcuries, providing that the radium-228 is present with the parent thorium-232, regardless of concentration in the solid.

Stue, Auth.: ORS Ch. 469

Bin: EFSC 2-1978, f. 12-28-78, \&. 3-1-79

\section{Pother Exemption}

345-50-035 Naturally occurring radioactive materials shall be exempt from the provisions of rule 345-50-006 (or ORS 469.525) if it can be demonsurated that accumulation of material will not result in exposures exceeding 500 millirem of external gamma radiation per year, nor in the release of effluents to air and water in annual average concentrations exceeding the values in Table 3. An evaluation of potentia radiation exposures and effluent releases stall be performed using the following premises:

(1) The material shall be considered in the form it exists when it is reanoved from the users' equipment, systems, or setting ponds prior to any dilution or remedial action designed to reduce radiation levels.

(2) No considerstion shall be given to the ameliornting effects of land use restrictions, maintenance operations, or overburden at the disposal sire.

(3) Accumulations of material over the reasonably projected period of waste generation shall be evaluated.

(4) External gamma radiation exposures shall be based on actual measurement and allowance may be made for the degree of equilibrium and for self-shielding.

(I) In computing radon concentrations in the air above a disposal site containing radium-226, the following additional premises shall be used:

(a) Any house built on ground contaminated with radium. 206 is assumed to have an 8 foot high oeiling on the first floor. to have one complete air change per bour, and to have a foundation constructed so as to meet the Structural Speciaity Code (State of Oregon Uniform Building Code) effective at the time of adoption of these rules. No consideration will be allowed for any special construction or treatmeats designed to reduce radon diffusion into the structure.

(b) The relation between radon-emanation rate and radium concentration will be based upon experimental measurements oa material incended for disposal.

Sent Auth: ORS Ch. 460

Hin: EFSC \&-1978, 1. 12-28-78, et. 3-1-79 


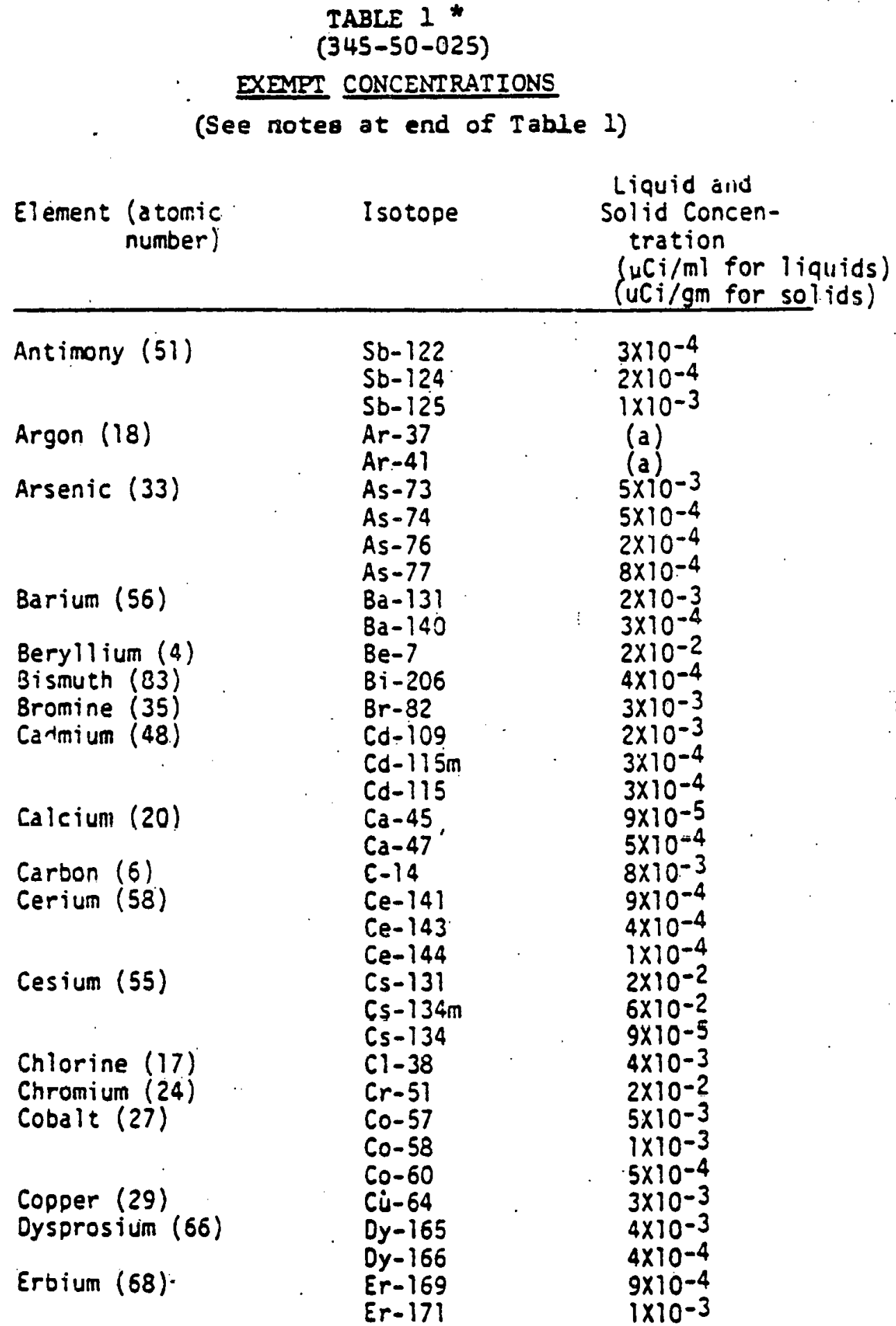

Unless otherwise noted, this table is identical to schedule A, Part B of the State of Oregon Regulations for the Control of Radiation. 


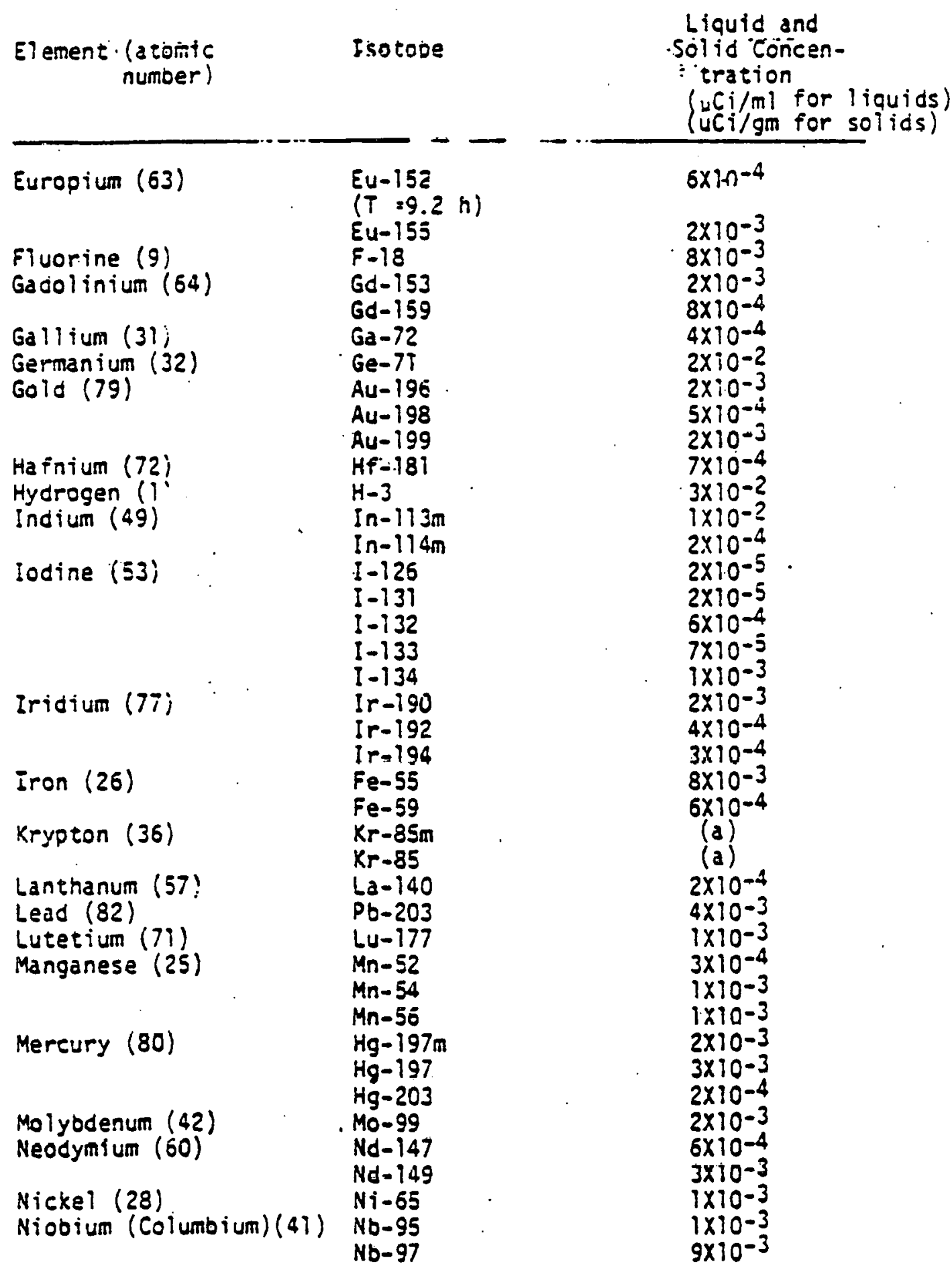




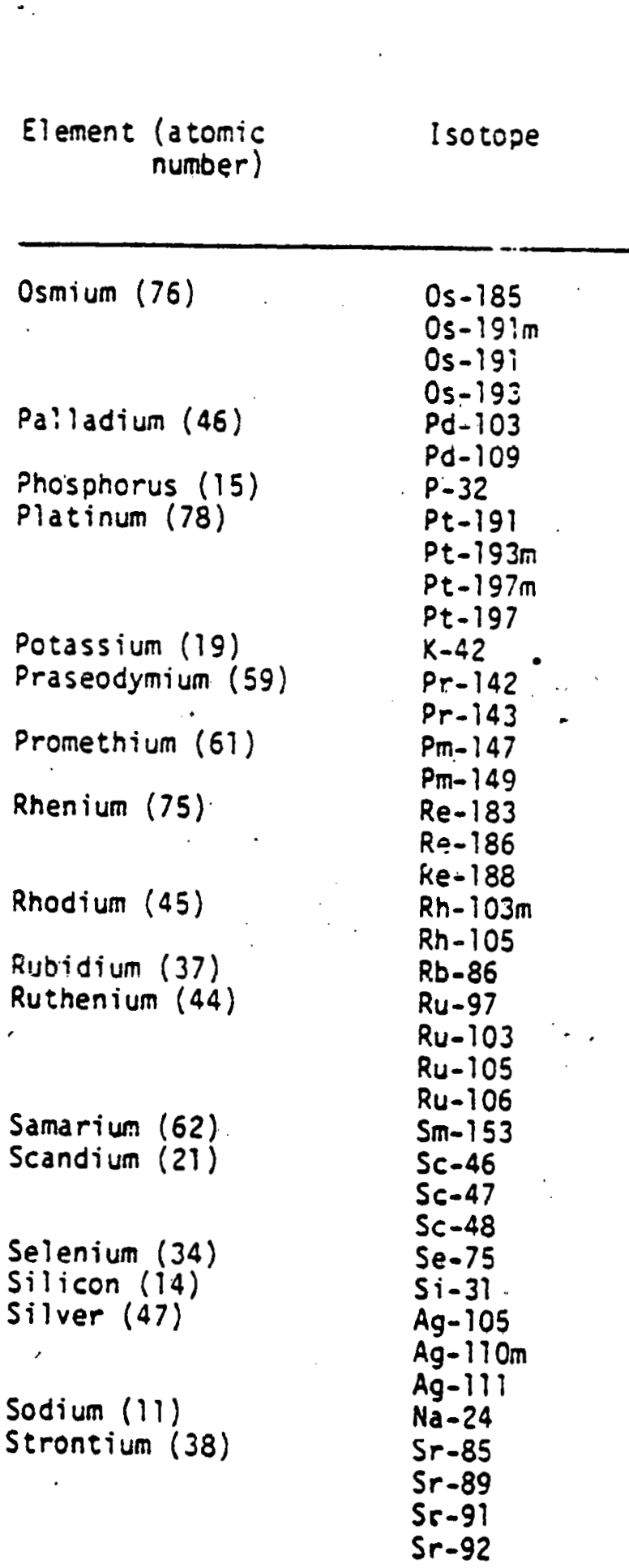

Liquid and

Solid Concen-

tration

( $u \mathrm{Ci} / \mathrm{ml}$ for liquids)

(uCi/gm for solids)

$7 \times 10^{-4}$

$3 \times 10^{-2}$

$2 \times 10^{-3}$

$6 \times 10^{-4}$

$3 \times 10-3$

$9 \times 10^{-4}$

$2 \times 10^{-4}$

$1 \times 10^{-3}$

$1 \times 10^{-2}$

$1 \times 10^{-2}$

$1 \times 10^{-3}$

$3 \times 10-3$

$3 \times 10^{-4}$

$5 \times 10^{-4}$

$2 \times 10^{-3}$

$4 \times 10^{-4}$

$6 \times 10^{-3}$

$9 \times 10^{-4}$

$6 \times 10-4$

$1 \times 10^{-1}$

$1 \times 10^{-3}$

$7 \times 10^{-4}$

$4 \times 10^{-3}$

$8 \times 10^{-4}$

$1 \times 10^{-3}$

$1 \times 10^{-4}$

$8 \times 10^{-4}$

$4 \times 10^{-4}$

$9 \times 10^{-4}$

$3 \times 10^{-4}$

$3 \times 10-3$

$9 \times 10^{-3}$

$1 \times 10^{-3}$

$3 \times 10^{-4}$

$4 \times 10^{-4}$

$2 \times 10^{-3}$

$1 \times 10^{-3}$

$1 \times 10^{-4}$

$7 \times 10^{-4}$

$7 \times 10^{-4}$ 


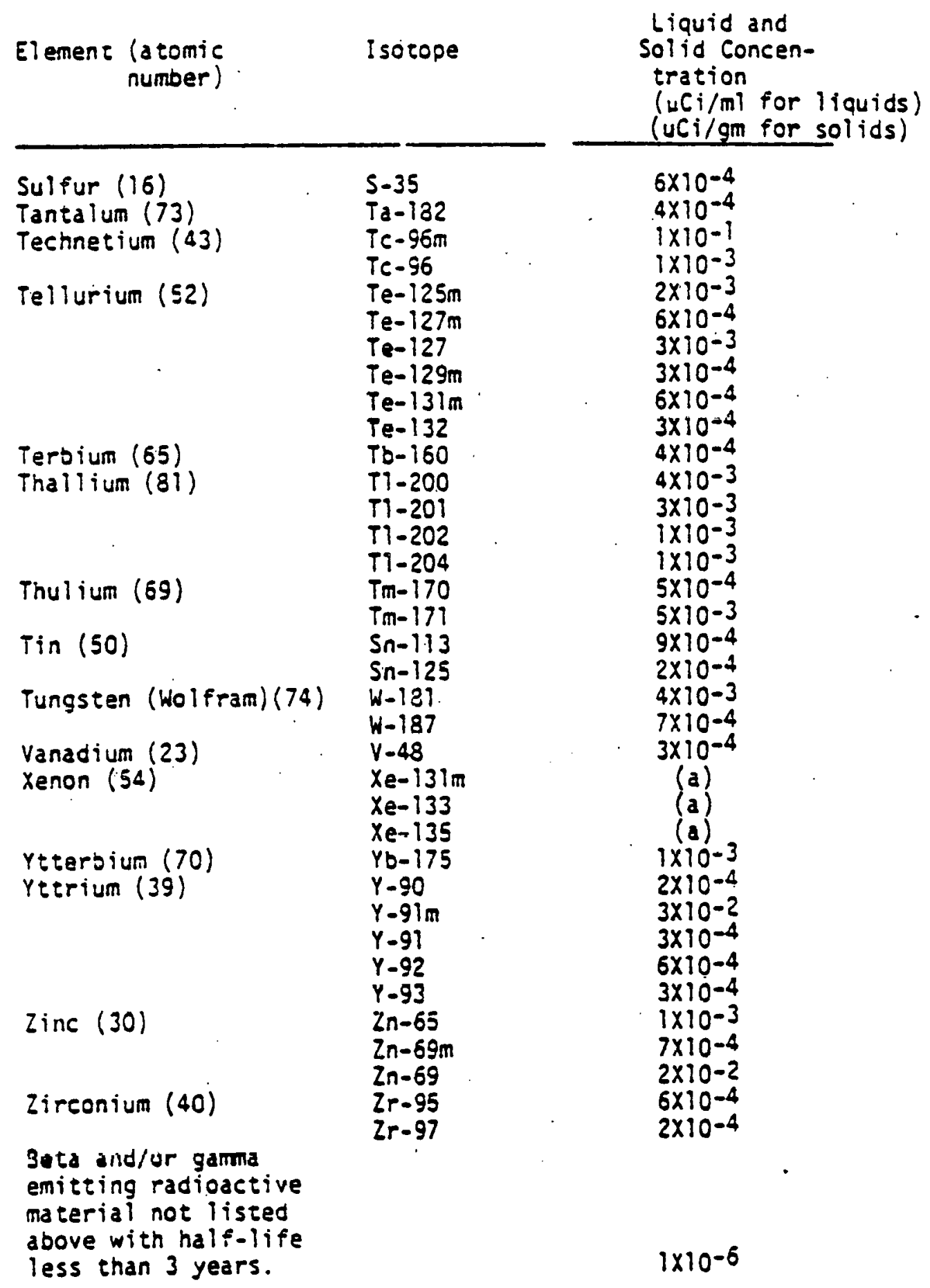


NOTE 1. Many radioisotopes disintegrate into isotopes which are also radioactive. In expressing the concentrations in Table I the activity stated is that of the parent isotope and takes into account the dauginters.

NOTE 2. For purposes of OAR 345-50-025 where there is involved a combination of isotopes, the limit for the combination should be derived as follows: Determine for each isotope in the product the ratio between the concentration present in the product and the exemp: concentration established in Table I for the specific isotope when not in combiration. The sum of such ratios may not exceed "l" (i.e., unity).

EXAMPLE:

$\frac{\text { Concentration of Isotope A in Product }}{\text { Exempt concentration of Isotope } A}+\frac{\text { Concentration of Isotope } 8 \text { in Product }}{\text { Exempt concentration of Isotope } B} \leq 1$

(a) These rules are intended to apply only to liquid or solid wastes. 


\begin{tabular}{|c|c|c|c|c|}
\hline \multirow[b]{2}{*}{$\begin{array}{l}\text { Radióactive } \\
\text { Material }\end{array}$} & \multicolumn{4}{|c|}{ EXEMPT QUANT ITIES } \\
\hline & Microcuries & $\begin{array}{l}\text { Radioactive } \\
\text { Material }\end{array}$ & Micr & rocuries \\
\hline 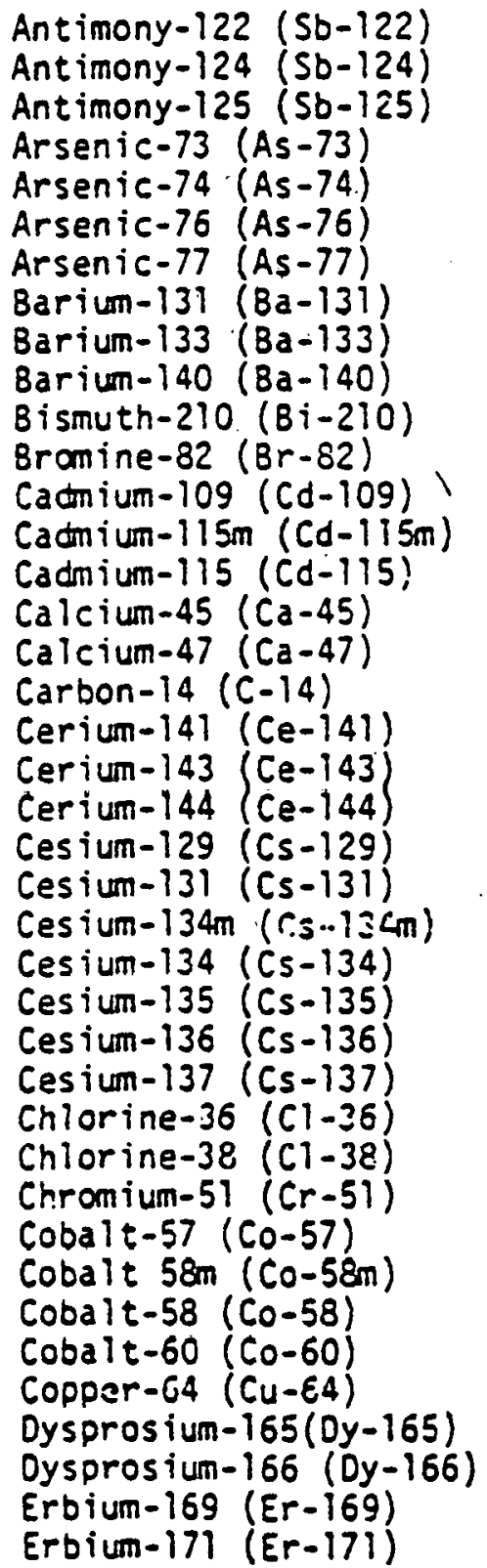 & $\begin{array}{r}100 \\
10 \\
10 \\
100 \\
10 \\
10 \\
100 \\
10 \\
10 \\
10 \\
1 \\
10 \\
10 \\
10 \\
100 \\
10 \\
10 \\
100 \\
100 \\
100 \\
1 \\
100 \\
100 \\
100 \\
1 \\
10 \\
10 \\
10 \\
10 \\
10 \\
1000 \\
100 \\
10 \\
10 \\
1 \\
100 \\
10 \\
100 \\
100 \\
100 \\
10 \\
10 \\
10 \\
10 \\
10 \\
10\end{array}$ & 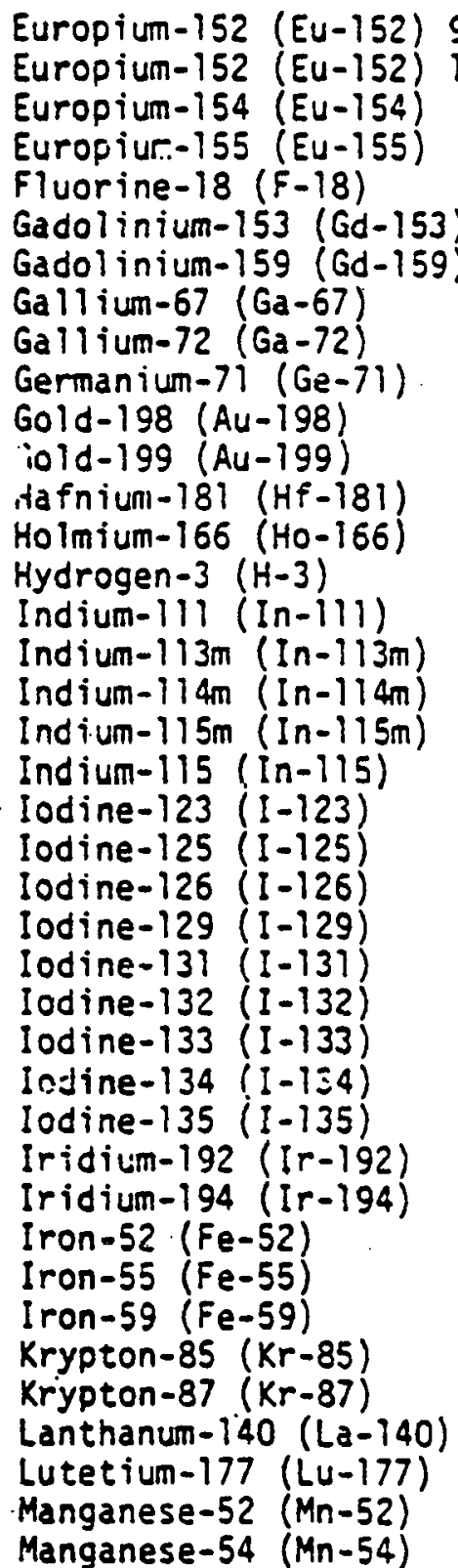 & $\begin{array}{l}9.2 \mathrm{~h} \\
13 \mathrm{yr} \\
\text { ) } \\
\text { ) }\end{array}$ & $\begin{array}{r}100 \\
1 \\
1 \\
10 \\
1,000 \\
10 \\
100 \\
100 \\
10 \\
100 \\
100 \\
100 \\
10 \\
100 \\
1000 \\
100 \\
100 \\
10 \\
100 \\
10 \\
100 \\
1 \\
1 \\
10 \\
0\end{array}$ \\
\hline
\end{tabular}

-Unless otherwise noted, this table is identical to Schedule $C$, Part B of the State of Oregon Regulations for the Control of Radiation. 
OREGON ADMINISTRATIVE RULES

CEAPIER 34, DIVISION SO-ENERGY FACIINX STILNG COUNCAL

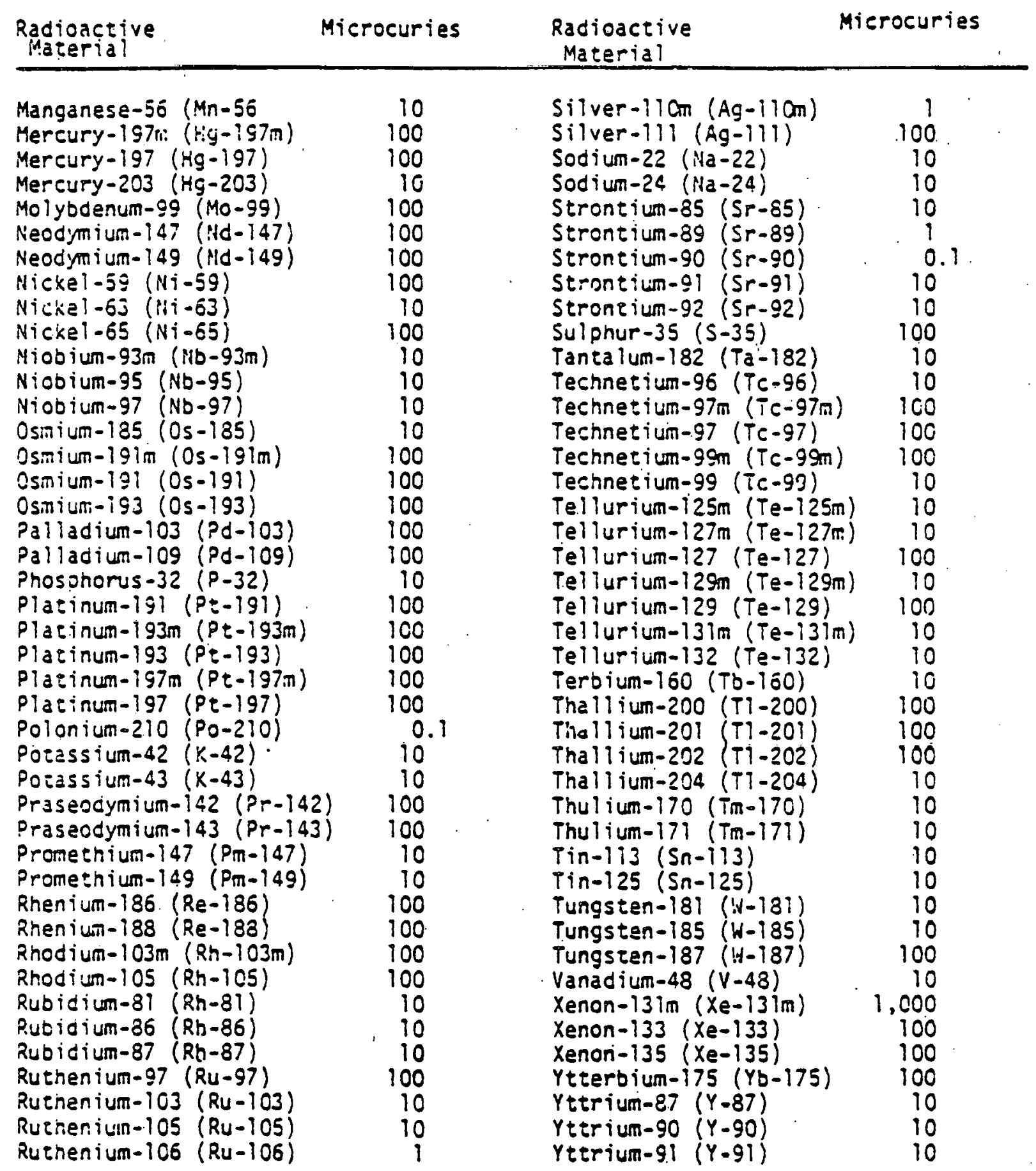




\begin{tabular}{|c|c|c|}
\hline $\begin{array}{l}\text { Samarium-157 }(\mathrm{Sm}-151) \\
\text { Samarium-153 }(\mathrm{Sm}-153) \\
\text { Scandium-46 }(\mathrm{Sc}-46) \\
\text { Scandium-47 }(\mathrm{Sc}-47) \\
\text { Scandium-48 }(\mathrm{Sc}-48) \\
\text { Selenium-75 }(\mathrm{Se}-75) \\
\text { Silicon-31 }(\mathrm{Si}-31) \\
\text { Silver-105 (Ag-105) }\end{array}$ & $\begin{array}{r}10 \\
100 \\
10 \\
100 \\
10 \\
10 \\
100 \\
10\end{array}$ & $\begin{array}{l}\text { Yttrium-92 }(Y-92) \\
\text { Yttrium-93 }(Y-93) \\
\text { Zinc-65 (Zn-65) } \\
\text { Zinc-69m }(2 n-69 m) \\
\text { Zinc-69 (Zn-69) } \\
\text { Zirconium-93 (Zr-93) } \\
\text { Zirconium-95 (Zr-95) } \\
\text { Zirconium-97 (Zr-97) }\end{array}$ \\
\hline
\end{tabular}

Any radioactive material not listed above other than alpha emittins radioactive material

0.1 


\section{TABLE $9 *$}

CONCENTRATIONS IN AIR ANO WATER ABOVE MATURAL BACKGROUND

(345-50-035)

(See notes at end of Table 3

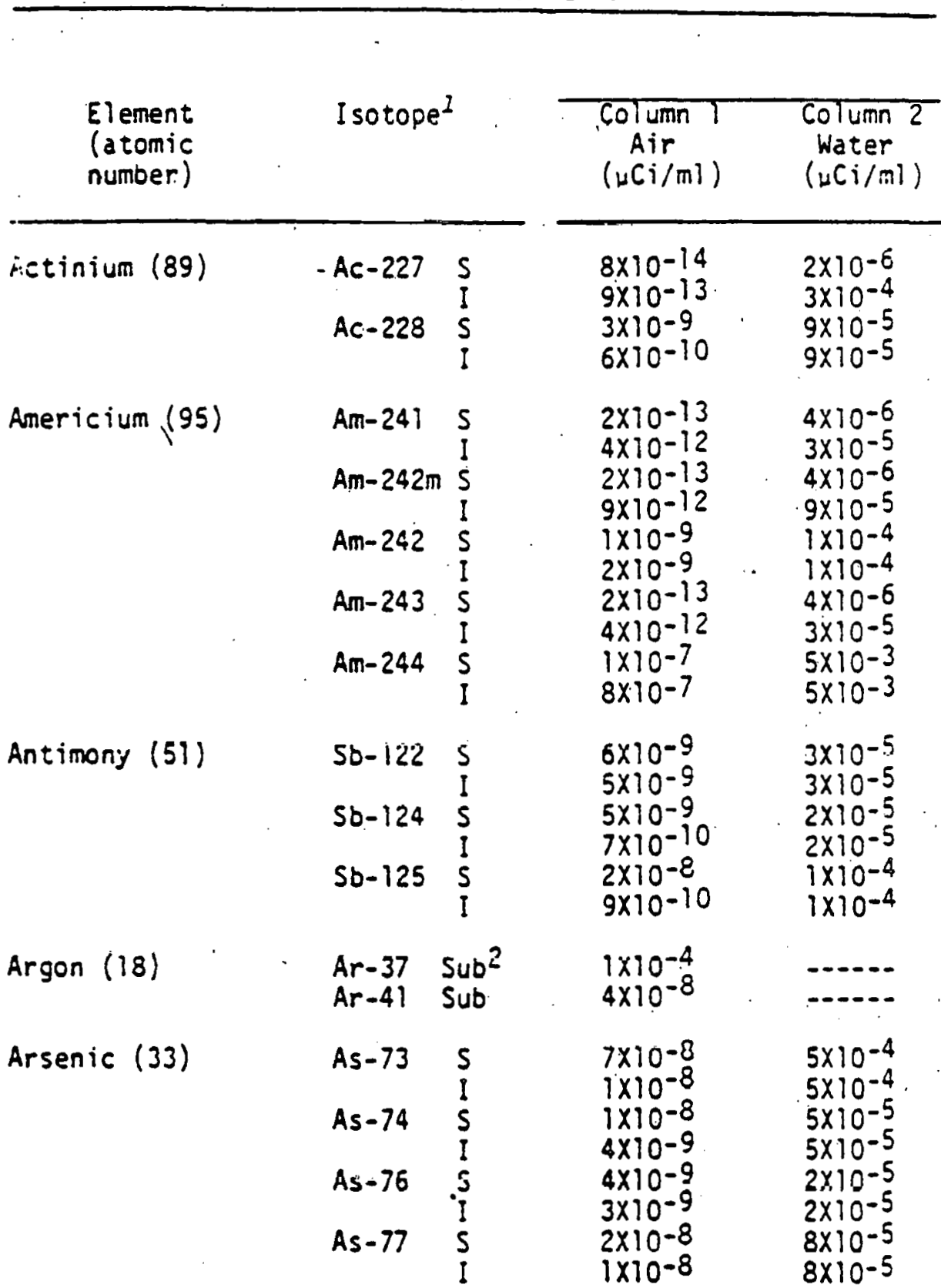

*Unless otherwise noted, this table is copied from Table II, Appendix A, Part $C$ of the State of Oregon Regulations for the Control of Radiation. 


\begin{tabular}{|c|c|c|c|c|c|}
\hline $\begin{array}{l}\text { Element } \\
\text { (Atomic } \\
\text { numneri }\end{array}$ & & I'sotode ${ }^{i}$ & & $\begin{array}{l}\text { Column:? } \\
\text { Air } \\
(u C i / m !)\end{array}$ & $\begin{array}{l}\text { Colum } 2 \\
\text { Water } \\
(\mathrm{iCi} / \mathrm{mi})\end{array}$ \\
\hline Astatine (85) & ' & At-211 & $\begin{array}{l}5 \\
l\end{array}$ & $\begin{array}{l}2 \times 10^{-i i}: i \vdots \\
.1 \times 10^{-9}\end{array}$ & $\begin{array}{l}2 \times 10^{-5} \\
7 \times 10^{-5}\end{array}$ \\
\hline Barium (56) & & $\begin{array}{l}8 a-131 \\
8 a-140\end{array}$ & $\begin{array}{l}s \\
1 \\
s \\
\vdots\end{array}$ & $\begin{array}{l}4 \times 10^{-8} \\
1 \times 10^{-8} \\
4 \times 10^{-9} \\
1 \times 10^{-9}\end{array}$ & $\begin{array}{l}2 \times 10^{-4} \\
2 \times 10^{-4} \\
3 \times 10^{-5} \\
2 \times 10^{-5}\end{array}$ \\
\hline Berkel ium (97) & & $\begin{array}{l}8 k-249 \\
8 k-250\end{array}$ & $\begin{array}{l}5 \\
1 \\
5 \\
1\end{array}$ & $\begin{array}{l}3 \times 10^{-11} \\
4 \times 10^{-9} \\
5 \times 10^{-9} \\
4 \times 10^{-8}\end{array}$ & $\begin{array}{l}6 \times 10^{-4} \\
6 \times 10^{-4} \\
2 \times 10^{-4} \\
2 \times 10^{-4}\end{array}$ \\
\hline Beryllium (4) & & 'Be-1 & $\begin{array}{l}S \\
I\end{array}$ & $\begin{array}{l}2 \times 10-7 \\
4 \times 10^{-8}\end{array}$ & $\begin{array}{l}2 \times 10^{-3} \\
2 \times 10^{-3}\end{array}$ \\
\hline Bismuen (83) & & $\begin{array}{l}8 i-206 \\
8 i-207 \\
8 i-210 \\
B i-212\end{array}$ & $\begin{array}{l}5 \\
\vdots \\
5 \\
I \\
5 \\
I \\
5 \\
I\end{array}$ & $\begin{array}{l}5 \times 10^{-9} \\
5 \times 10^{-9} \\
6 \times 10^{-9} \\
5 \times 10^{-10} \\
2 \times 10^{-10} \\
2 \times 10^{-10} \\
3 \times 10^{-9} \\
7 \times 10^{-9}\end{array}$ & $\begin{array}{l}4 \times 10^{-5} \\
4 \times 10^{-5} \\
6 \times 10^{-5} \\
5 \times 10^{-5} \\
4 \times 10^{-5} \\
4 \times 10^{-5} \\
4 \times 10^{-4} \\
4 \times 10^{-4}\end{array}$ \\
\hline Bromine (35) & & $8 r-82$ & $\begin{array}{l}5 \\
1\end{array}$ & $\begin{array}{l}4 \times 10^{-8} \\
6 \times 10^{-9}\end{array}$ & $\begin{array}{l}3 \times 10^{-4} \\
4 \times 10^{-5}\end{array}$ \\
\hline Cadmium (48) & & $\begin{array}{l}c d-109 \\
c d-115 m \\
c d-115\end{array}$ & $\begin{array}{l}5 \\
1 \\
5 \\
I \\
5 \\
l\end{array}$ & $\begin{array}{l}2 \times 10^{-9} \\
3 \times 10^{-9} \\
1 \times 10^{-9} \\
1 \times 10^{-9} \\
8 \times 10^{-9} \\
6 \times 10^{-9}\end{array}$ & $\begin{array}{l}2 \times 10^{-4} \\
2 \times 10^{-4} \\
3 \times 10^{-5} \\
3 \times 10^{-5} \\
3 \times 10^{-5} \\
4 \times 10^{-5}\end{array}$ \\
\hline Calcium (20) & & $\begin{array}{c}C a-45 \\
C a-47 \\
.\end{array}$ & $\begin{array}{l}S \\
I \\
5 \\
!\end{array}$ & $\begin{array}{l}1 \times 10^{-9} \\
4 \times 10^{-9} \\
6 \times 10^{-9} \\
6 \times 10^{-9}\end{array}$ & $\begin{array}{l}9 \times 10^{-6} \\
2 \times 10^{-4} \\
5 \times 10^{-5} \\
3 \times 10^{-5}\end{array}$ \\
\hline Californium (98) & & $C f-249$ & S & $\begin{array}{l}5 \times 10-14 \\
3 \times 10-12\end{array}$ & $\begin{array}{l}4 \times 10^{-6} \\
2 \times 10^{-5}\end{array}$ \\
\hline
\end{tabular}




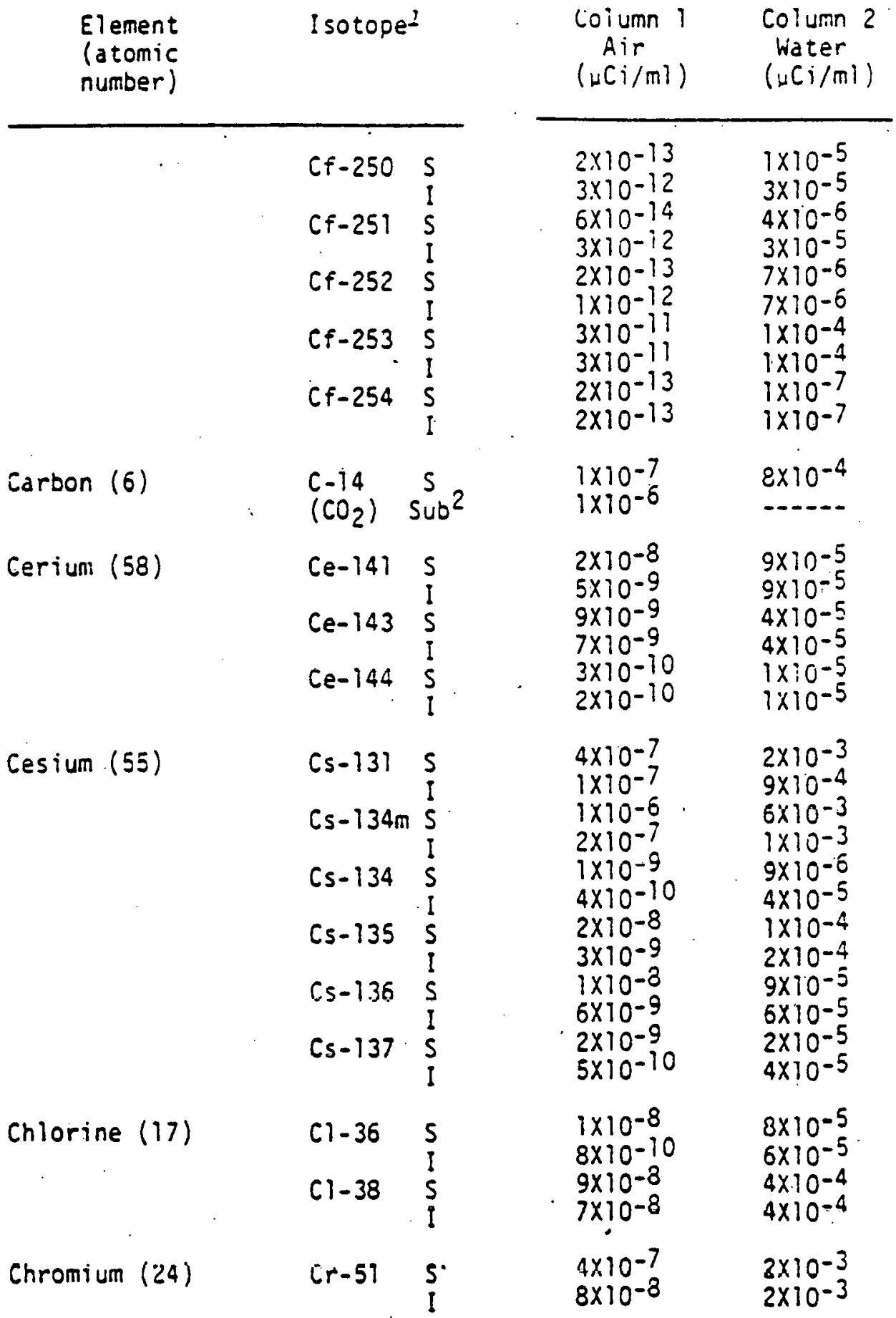




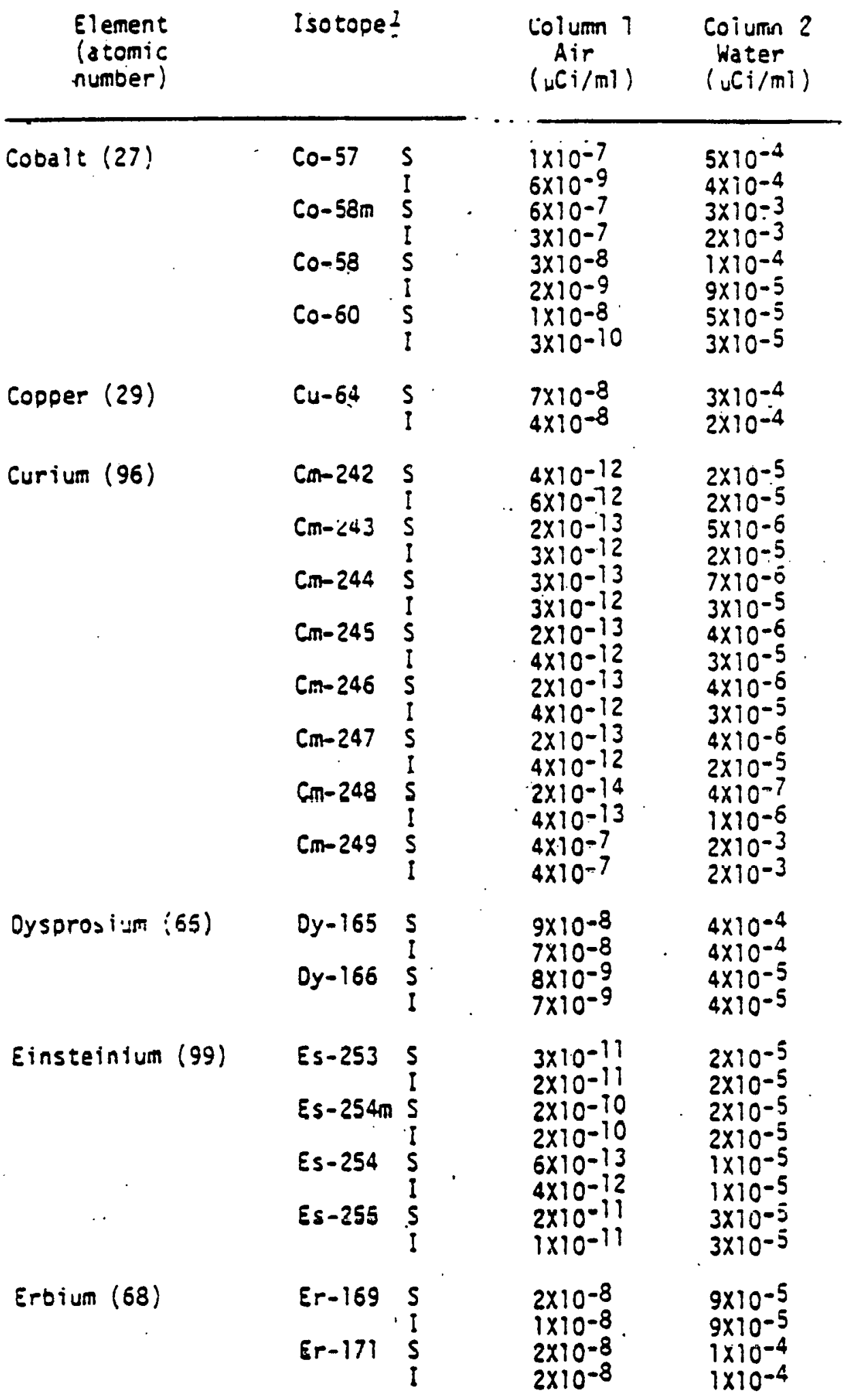

$(6-1-79)$ 


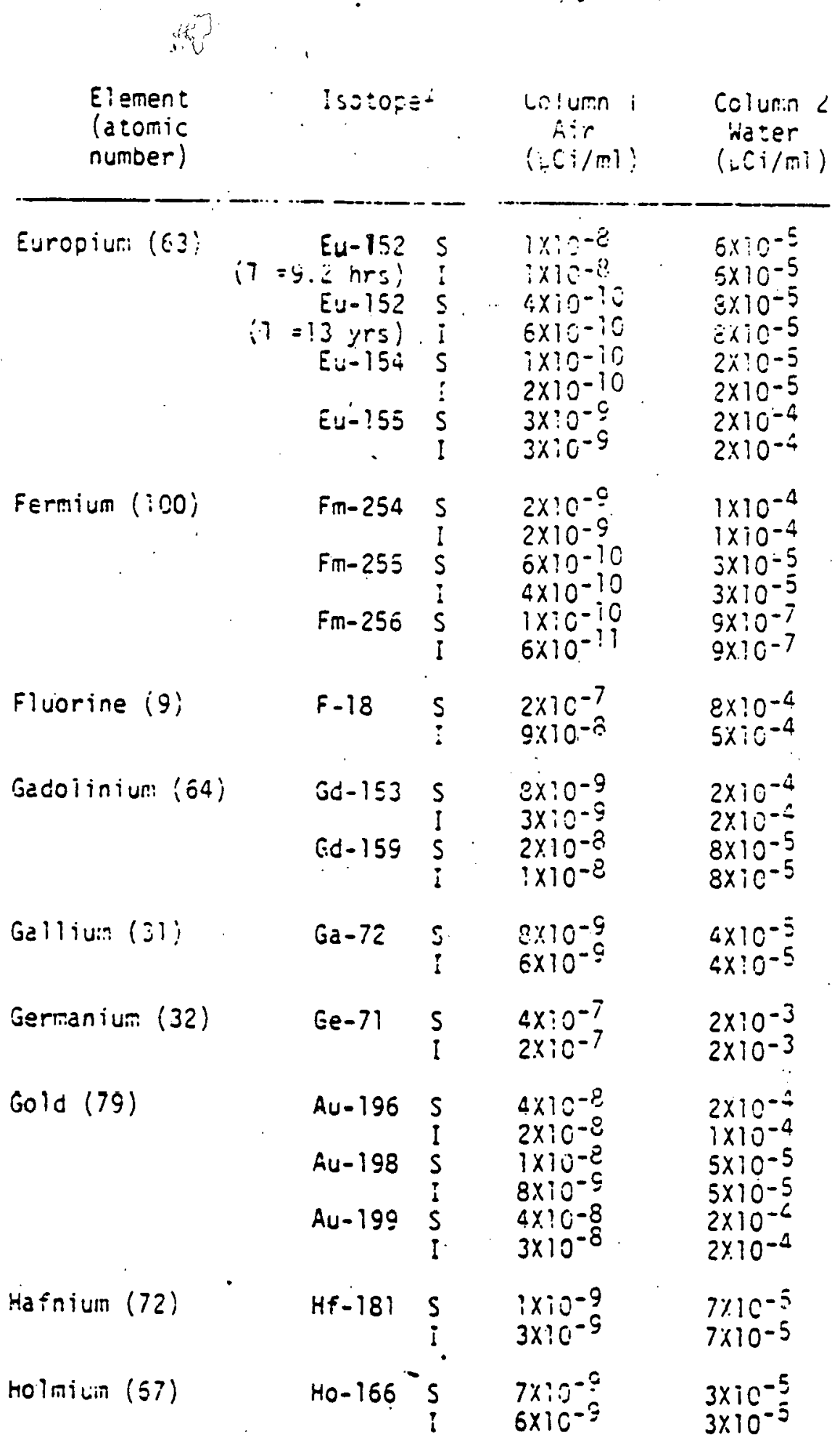


ORECON ADMONTSTRATTVE RULES

CEATID 34. DVISTON SD - EVERG FACUITY SINAG COUNCII

\begin{tabular}{|c|c|c|c|}
\hline $\begin{array}{l}\text { Element } \\
\text { (atomic } \\
\text { number) }\end{array}$ & Isornoel & $\begin{array}{l}\text { Column-1 } \\
\text { Air } \\
(u r i / m i)\end{array}$ & $\begin{array}{l}\text { Colum } 2 \\
\text { Water } \\
(u \mathrm{C} i / m i)\end{array}$ \\
\hline Hydrogen (i) & $\begin{array}{c}H-3 . \\
\\
\text { Sut }^{2}\end{array}$ & $\begin{array}{l}2 \times 10^{-7} \\
2 \times 10^{-7} \\
4 \times 10^{-5}\end{array}$ & $\begin{array}{l}3 \times 10^{-3} \\
3 \times 10^{-3}\end{array}$ \\
\hline Indium (49) & $\begin{array}{ll}\text { In-113m } & S \\
& ! \\
\text { In-114m } & 5 \\
& \\
\text { In-115m } & 5 \\
& ! \\
\text { In-115 } & 5 \\
& I\end{array}$ & $\begin{array}{l}3 \times 10^{-7} \\
2 \times 10^{-7} \\
4 \times 10^{-9} \\
7 \times 10^{-10} \\
8 \times 10^{-8} \\
6 \times 10^{-8} \\
9 \times 10^{-9} \\
1 \times 10^{-9}\end{array}$ & $\begin{array}{l}1 \times 10^{-3} \\
1 \times 10^{-3} \\
2 \times 10^{-5} \\
2 \times 10^{-5} \\
4 \times 10^{-4} \\
4 \times 10^{-4} \\
9 \times 10^{-5} \\
9 \times 10^{-5}\end{array}$ \\
\hline lodine $(53)$ & $\begin{array}{ll}I-125 & 5 \\
I=126 & 5 \\
& ! \\
I-129 & 5 \\
& ! \\
I-131 & 5 \\
& ! \\
I-132 & 5 \\
& I \\
I=133 & 5 \\
& I \\
I-134 & 5 \\
& I \\
I-135 & 5 \\
& I\end{array}$ & $\begin{array}{l}8 \times 10^{-11} \\
6 \times 10^{-9} \\
9 \times 10^{-11} \\
=1 \times 10^{-8} \\
2 \times 10^{-11} \\
2 \times 10^{-9} \\
1 \times 10^{-10} \\
1 \times 10^{-8} \\
3 \times 10^{-9} \\
3 \times 10^{-8} \\
4 \times 10^{-10} \\
7 \times 10^{-9} \\
6 \times 10^{-9} \\
1 \times 10^{-7} \\
1 \times 10^{-9} \\
1 \times 10^{-8}\end{array}$ & $\begin{array}{l}2 \times 10^{-7} \\
2 \times 10^{-4} \\
3 \times 10^{-7} \\
9 \times 10^{-5} \\
.6 \times 10^{-8} \\
-2 \times 10^{-4} \\
3 \times 10^{-7} \\
6 \times 10^{-5} \\
8 \times 10^{-6} \\
2 \times 10^{-4} \\
1 \times 10^{-6} \\
4 \times 10^{-5} \\
2 \times 10^{-5} \\
6 \times 10^{-4} \\
4 \times 10^{-6} \\
7 \times 10^{-5}\end{array}$ \\
\hline Iridium $(77)$ & $\begin{array}{ll}I r-190 & s \\
& I \\
I r-192 & 5 \\
& ! \\
I r-194 & 5 \\
& I\end{array}$ & $\begin{array}{l}4 \times 10^{-8} \\
1 \times 10^{-8} \\
4 \times 10^{-9} \\
9 \times 10^{-10} \\
8 \times 10^{-9} \\
5 \times 10^{-9}\end{array}$ & $\begin{array}{l}2 \times 10^{-4} \\
2 \times 10^{-4} \\
4 \times 10^{-5} \\
4 \times 10^{-5} \\
3 \times 10^{-5} \\
3 \times 10^{-5}\end{array}$ \\
\hline Iron (26) & $\begin{array}{ll}F e-5 j & s \\
& l \\
F e=59 & S \\
& l\end{array}$ & $\begin{array}{l}3 \times 10^{-8} \\
3 \times 10^{-8} \\
5 \times 10^{-9} \\
2 \times 10^{-9}\end{array}$ & $\begin{array}{l}8 \times 10^{-4} \\
2 \times 10^{-3} \\
6 \times 10^{-5} \\
5 \times 10^{-5}\end{array}$ \\
\hline Krypton (36) & $\begin{array}{ll}K r-85 m & S u b^{2} \\
K r-85 & \text { Sub } \\
K r-87 & \text { Sub } \\
K r-88 & \text { Sub }\end{array}$ & $\begin{array}{l}1 \times 10^{-7} \\
3 \times 10^{-7} \\
2 \times 10^{-8} \\
2 \times 10^{-8}\end{array}$ & n-n \\
\hline
\end{tabular}

$(6-1-79)$

6- Tahle 3 


\begin{tabular}{|c|c|c|c|c|}
\hline $\begin{array}{l}\text { Element } \\
\text { (atomic } \\
\text { number) }\end{array}$ & Isotope' & & $\begin{array}{l}\text { Coiumn } 1 \\
\text { Air } \\
(:=C i / m l)\end{array}$ & $\begin{array}{l}\text { Colunial } 2 \\
\text { Water } \\
(u C i / m i)\end{array}$ \\
\hline Lanthanum (57) & $\operatorname{La}-140$ & $\begin{array}{l}s \\
I\end{array}$ & $\begin{array}{l}5 \times 10^{-9} \\
4 \times 10^{-9}\end{array}$ & $\begin{array}{l}2 \times 10^{-5} \\
2 \times 10^{-5}\end{array}$ \\
\hline $\begin{array}{c}\text { Lead (22) } \\
\qquad\end{array}$ & $\begin{array}{l}P b-203 \\
P b-210 \\
P b-212\end{array}$ & $\begin{array}{l}5 \\
I \\
S \\
1 \\
5 \\
I\end{array}$ & $\begin{array}{l}9 \times 10^{-8} \\
6 \times 10^{-8} \\
4 \times 10^{-12} \\
8 \times 10^{-12} \\
6 \times 10^{-10} \\
7 \times 10^{-10}\end{array}$ & $\begin{array}{l}4 \times 10^{-4} \\
4 \times 10^{-4} \\
1 \times 10^{-7} \\
2 \times 10^{-4} \\
2 \times 10^{-5} \\
2 \times 10^{-5}\end{array}$ \\
\hline Lutetium (71) & $L u-177$ & S & $\begin{array}{l}2 \times 10^{-8} \\
2 \times 10^{-8}\end{array}$ & $\begin{array}{l}1 \times 10^{-4} \\
1 \times 10^{-4}\end{array}$ \\
\hline Manganese (25) & $\begin{array}{l}M n-52 \\
M n-54 \\
M n-56\end{array}$ & $\begin{array}{l}5 \\
1 \\
5 \\
1 \\
5 \\
1\end{array}$ & $\begin{array}{l}7 \times 10^{-9} \\
5 \times 10^{-9} \\
1 \times 10^{-8} \\
1 \times 10^{-9} \\
3 \times 10^{-8} \\
2 \times 10^{-3}\end{array}$ & $\begin{array}{l}3 \times 10^{-5} \\
3 \times 10^{-5} \\
1 \times 10^{-4} \\
1 \times 10^{-4} \\
1 \times 10^{-4} \\
1 \times 10^{-4}\end{array}$ \\
\hline Mercury (80) & $\begin{array}{l}\mathrm{Hg}-1.27 \mathrm{~m} \\
\mathrm{Hg}-197 \\
\mathrm{Hg}-203\end{array}$ & $\begin{array}{l}5 \\
1 \\
5 \\
1 \\
5 \\
1\end{array}$ & $\begin{array}{l}3 \times 10^{-8} \\
3 \times 10^{-8} \\
4 \times 10^{-8} \\
9 \times 10^{-8} \\
2 \times 10^{-9} \\
4 \times 10^{-9}\end{array}$ & $\begin{array}{l}2 \times 10^{-4} \\
2 \times 10^{-4} \\
3 \times 10^{-4} \\
5 \times 10^{-4} \\
2 \times 10^{-5} \\
1 \times 10^{-4}\end{array}$ \\
\hline Moiybdenum $(\$ 2)$ & Mo-99 & $\begin{array}{l}\mathrm{S} \\
\mathrm{I}\end{array}$ & $\begin{array}{l}3 \times 10^{-8} \\
7 \times 10^{-9}\end{array}$ & $\begin{array}{l}2 \times 10^{-4} \\
4 \times 10^{-5}\end{array}$ \\
\hline Neodymium $(60)$ & $\begin{array}{l}\text { Nd-144 } \\
N d-147 \\
N d-149\end{array}$ & $\begin{array}{l}5 \\
! \\
5 \\
\vdots \\
s \\
1\end{array}$ & $\begin{array}{l}3 \times 10^{-12} \\
1 \times 10^{-11} \\
1 \times 10^{-8} \\
8 \times 10^{-9} \\
6 \times 10^{-8} \\
5 \times 10^{-8}\end{array}$ & $\begin{array}{l}7 \times 10^{-5} \\
8 \times 10^{-5} \\
6 \times 10^{-5} \\
6 \times 10^{-5} \\
3 \times 10^{-4} \\
3 \times 10^{-4}\end{array}$ \\
\hline Neptunium (93) & $\begin{array}{l}N p-237 \\
N p-239\end{array}$ & $\begin{array}{l}5 \\
! \\
S \\
I\end{array}$ & $\begin{array}{l}1 \times 10^{-13} \\
4 \times 10^{-12} \\
3 \times 10^{-8} \\
2 \times 10^{-8}\end{array}$ & $\begin{array}{l}3 \times 10^{-6} \\
3 \times 10^{-5} \\
1 \times 10^{-4} \\
1 \times 10^{-4}\end{array}$ \\
\hline inickel (28) & $\begin{array}{l}\mathrm{Ni}-59 \\
\mathrm{Ni}-63\end{array}$ & $\begin{array}{l}5 \\
I \\
S \\
I\end{array}$ & $\begin{array}{l}2 \times 10^{-8} \\
3 \times 10^{-8} \\
2 \times 10^{-9} \\
1 \times 10^{-8}\end{array}$ & $\begin{array}{l}2 \times 10^{-4} \\
2 \times 10^{-3} \\
3 \times 10^{-5} \\
7 \times 10^{-4}\end{array}$ \\
\hline
\end{tabular}


ORECON ADMTNISTRATTVE RUZES

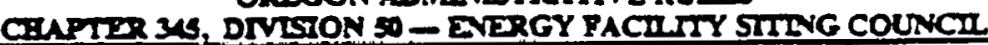

\begin{tabular}{|c|c|c|c|c|c|}
\hline & $\begin{array}{l}\text { Element } \\
\text { (atomic } \\
\text { number) }\end{array}$ & Isotope & & $\begin{array}{l}\text { Column I. } \\
\text { Air. - } \\
(\text { Ci/mi) }\end{array}$ & $\begin{array}{c}\text { Column } \\
\text { Water } \\
(u C i / m))\end{array}$ \\
\hline & & $\mathrm{Ni}-65$ & s. & $\begin{array}{l}3 \times 10^{-8} \\
2 \times 10^{-8}\end{array}$ & $\begin{array}{l}1 \times 10^{-4} \\
1 \times 10^{-4}\end{array}$ \\
\hline & Niobium (41) & $\begin{array}{l}\text { Nb- } 93 m \\
N b-95 \\
N b-97\end{array}$ & $\begin{array}{l}5 \\
1 \\
5 \\
1 \\
5 \\
1\end{array}$ & $\begin{array}{l}4 \times 10^{-9} \\
5 \times 10^{-9} \\
2 \times 10^{-8} \\
3 \times 10^{-9} \\
2 \times 10^{-7} \\
2 \times 10^{-7}\end{array}$ & $\begin{array}{l}4 \times 10^{-4} \\
4 \times 10^{-4} \\
1 \times 10^{-4} \\
1 \times 10^{-4} \\
9 \times 10^{-4} \\
9 \times 10^{-4}\end{array}$ \\
\hline & Osmium (75) & $\begin{array}{l}0 s-185 \\
0 s-191 m \\
0 s-191 \\
0 s-193\end{array}$ & $\begin{array}{l}5 \\
1 \\
5 \\
1 \\
5 \\
1 \\
5 \\
1\end{array}$ & $\begin{array}{l}2 \times 10^{-8} \\
2 \times 10^{-9} \\
2 \times 10^{-7} \\
3 \times 10^{-7} \\
4 \times 10^{-8} \\
1 \times 10^{-8} \\
1 \times 10^{-8} \\
9 \times 10^{-9}\end{array}$ & $\begin{array}{l}7 \times 10^{-5} \\
7 \times 10^{-5} \\
3 \times 10^{-3} \\
2 \times 10^{-3} \\
2 \times 10^{-4} \\
2 \times 10^{-4} \\
6 \times 10^{-5} \\
5 \times 10^{-5}\end{array}$ \\
\hline & Palladium (46) & $\begin{array}{l}P d-103 \\
P d-109\end{array}$ & $\begin{array}{l}5 \\
! \\
5 \\
1\end{array}$ & $\begin{array}{l}5 \times 10^{-8} \\
3 \times 10^{-8} \\
2 \times 10^{-8} \\
1 \times 10^{-8}\end{array}$ & $\begin{array}{l}3 \times 10^{-4} \\
3 \times 10^{-4} \\
9 \times 10^{-5} \\
7 \times 10^{-5}\end{array}$ \\
\hline & Phosphorus (15) & $p=32$ & $\begin{array}{l}5 \\
1\end{array}$ & $\begin{array}{l}2 \times 10^{-9} \\
3 \times 10^{-9}\end{array}$ & $\begin{array}{l}2 \times 10^{-5} \\
2 \times 10^{-5}\end{array}$ \\
\hline & Platinum (78) & $\begin{array}{l}\text { Pt-197 } \\
\text { Pt-193m } \\
\text { Pt-193 } \\
\text { Pt-197m } \\
\text { Pt-197 }\end{array}$ & $\begin{array}{l}5 \\
1 \\
5 \\
1 \\
5 \\
1 \\
5 \\
1 \\
5 \\
1\end{array}$ & $\begin{array}{l}3 \times 10^{-8} \\
2 \times 10^{-8} \\
2 \times 10^{-7} \\
2 \times 10^{-7} \\
4 \times 10^{-8} \\
1 \times 10^{-8} \\
2 \times 10^{-7} \\
2 \times 10^{-7} \\
3 \times 10^{-8} \\
2 \times 10^{-8}\end{array}$ & $\begin{array}{l}1 \times 10^{-4} \\
1 \times 10^{-4} \\
1 \times 10^{-3} \\
1 \times 10^{-3} \\
9 \times 10^{-4} \\
2 \times 10^{-3} \\
1 \times 10^{-3} \\
9 \times 10^{-4} \\
1 \times 10^{-4} \\
1 \times 10^{-4}\end{array}$ \\
\hline$\cdot$ & Plutonium (96) & $\begin{array}{l}P_{U-238} \\
P_{U-239} \\
P_{U-240} \\
P_{U-241} \\
P_{U-242}\end{array}$ & $\begin{array}{l}5 \\
5 \\
5 \\
1 \\
5 \\
1 \\
5 \\
1 \\
5 \\
1\end{array}$ & $\begin{array}{l}7 \times 10^{-14} \\
1 \times 10^{-12} \\
6 \times 10^{-14} \\
1 \times 10^{-12} \\
6 \times 10^{-14} \\
1 \times 10^{-12} \\
3 \times 10^{-12} \\
1 \times 10^{-9} \\
6 \times 10^{-14} \\
1 \times 10^{-12}\end{array}$ & $\begin{array}{l}5 \times 10^{-6} \\
3 \times 10^{-5} \\
5 \times 10^{-6} \\
3 \times 10^{-5} \\
5 \times 10^{-6} \\
3 \times 10^{-5} \\
2 \times 10^{-4} \\
1 \times 10^{-3} \\
5 \times 10^{-6} \\
3 \times 10^{-5}\end{array}$ \\
\hline
\end{tabular}

$(6-1-79)$

8- Table 3 


\begin{tabular}{|c|c|c|c|}
\hline $\begin{array}{l}\text { Element } \\
\text { (a tomic } \\
\text { number) }\end{array}$ & Isotope ${ }^{2}$ & $\begin{array}{l}\text { Column I } \\
\text { Air } \\
\left({ }_{u} \mathrm{Ci} / \mathrm{ml}\right)\end{array}$ & $\begin{array}{l}\text { Lolumn } 2 \\
\text { Water } \\
(\mathrm{u} C \mathrm{i} / \mathrm{ml})\end{array}$ \\
\hline$\therefore$ & $\begin{array}{ll}P u-243 & S \\
& I \\
P U-244 & 5 \\
& I\end{array}$ & $\begin{array}{l}6 \times 10^{-8} \\
8 \times 10^{-8} \\
6 \times 10^{-14} \\
1 \times 10^{-12}\end{array}$ & $\begin{array}{l}3 \times 10^{-4} \\
3 \times 10^{-4} \\
4 \times 10^{-6} \\
1 \times 10^{-5}\end{array}$ \\
\hline Polonium (84) & 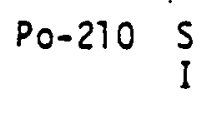 & $\begin{array}{l}2 \times 10^{-11} \\
7 \times 10^{-12}\end{array}$ & $\begin{array}{l}7 \times 10^{-7} \\
3 \times 10^{-5}\end{array}$ \\
\hline Potassium (19) & $k-42$ & $\begin{array}{l}7 \times 10^{-8} \\
4 \times 10^{-9}\end{array}$ & $\begin{array}{l}3 \times 10^{-4} \\
2 \times 10^{-5}\end{array}$ \\
\hline Praseodymium (59) & $\begin{array}{ll}\operatorname{Pr}-142 & 5 \\
& \\
\operatorname{Pr}-143 & 5\end{array}$ & $\begin{array}{l}7 \times 10^{-9} \\
5 \times 10^{-9} \\
1 \times 10^{-8} \\
6 \times 10^{-9}\end{array}$ & $\begin{array}{l}3 \times 10^{-5} \\
3 \times 10^{-5} \\
5 \times 10^{-5} \\
5 \times 10^{-5}\end{array}$ \\
\hline Promethium (6i) & $\begin{array}{ll}P_{m-14} & \mathrm{~S} \\
& \mathrm{I} \\
P_{m-149} & \mathrm{~S}\end{array}$ & $\begin{array}{l}2 \times 10^{-9} \\
3 \times 10^{-9} \\
1 \times 10^{-8} \\
8 \times 10^{-9}\end{array}$ & $\begin{array}{l}2 \times 10^{-4} \\
2 \times 10^{-4} \\
4 \times 10^{-5} \\
4 \times 10^{-5}\end{array}$ \\
\hline Protactinium $(91)$ & $\begin{array}{ll}P a-230 & S \\
& S \\
P a-231 & S \\
P a-233 & S \\
& I\end{array}$ & $\begin{array}{l}6 \times 10^{-11} \\
3 \times 10^{-11} \\
4 \times 10^{-14} \\
4 \times 10^{-12} \\
2 \times 10^{-8} \\
6 \times 10^{-9}\end{array}$ & $\begin{array}{l}2 \times 10^{-4}-4 \\
2 \times 10^{-4} \\
9 \times 10^{-7} \\
2 \times 10^{-5} \\
1 \times 10^{-4} \\
1 \times 10^{-4}\end{array}$ \\
\hline Radium (88) & $\begin{array}{ll}R a-223 & S \\
& I \\
R a-224 & 5 \\
R a-226 & S \\
R a-228 & S \\
& !\end{array}$ & $\begin{array}{l}6 \times 10^{-11} \\
8 \times 10^{-12} \\
2 \times 10^{-10}-11 \\
2 \times 10^{-11} \\
3 \times 10^{-12} \\
2 \times 10^{-12} \\
2 \times 10^{-12} \\
1 \times 10^{-12}\end{array}$ & $\begin{array}{l}7 \times 10^{-7} \\
4 \times 10^{-6} \\
2 \times 10^{-6} \\
5 \times 10^{-6} \\
3 \times 10^{-8} \\
3 \times 10^{-5} \\
3 \times 10^{-8} \\
3 \times 10^{-5}\end{array}$ \\
\hline Redon (86) & $\begin{array}{ll}R n-220 & 5 \\
R n-222 & S\end{array}$ & $\begin{array}{l}1 \times 10^{-8} \\
3 \times 10^{-9}\end{array}$ & - \\
\hline Rhenium (75) & $\operatorname{Re}-183^{\circ} \mathrm{S}$ & $\begin{array}{l}9 \times 10^{-8} \\
5 \times 10^{-9}\end{array}$ & $\begin{array}{l}6 \times 10^{-4} \\
3 \times 10^{-4}\end{array}$ \\
\hline
\end{tabular}


OREGON ADMONTSTRATIVE RULES

CENPTER 34, DIVSTON SO - DNERGY FACRITY SIIPG COUNCH.

\begin{tabular}{|c|c|c|c|c|c|}
\hline $\begin{array}{l}\text { Element } \\
\text { (a tomic } \\
\text { number) }\end{array}$ & & Isotope? & & $\begin{array}{l}\text { Colum I } \\
\text { Air } \\
(u C i / m l)\end{array}$ & $\begin{array}{l}\text { Column } 2 \\
\text { Water } \\
(\mathrm{uCi} / \mathrm{ml})\end{array}$ \\
\hline & & $\begin{array}{l}R e-186 \\
R e-187 \\
R e-188\end{array}$ & $\begin{array}{l}5 \\
1 \\
5 \\
1 \\
s \\
1\end{array}$ & $\begin{array}{l}2 \times 10^{-8} \\
8 \times 10^{-9} \\
3 \times 10^{-7} \\
2 \times 10^{-8} \\
1 \times 10^{-8} \\
6 \times 10^{-9}\end{array}$ & $\begin{array}{l}9 \times 10^{-5} \\
5 \times 10^{-5} \\
3 \times 10^{-3} \\
2 \times 10^{-3} \\
6 \times 10^{-5} \\
3 \times 10^{-5}\end{array}$ \\
\hline Rhodium (45) & & $\begin{array}{l}R h-103 m \\
R h-105\end{array}$ & $\begin{array}{l}5 \\
! \\
5 \\
I\end{array}$ & $\begin{array}{l}3 \times 10^{-6} \\
2 \times 10^{-6} \\
3 \times 10^{-8} \\
2 \times 10^{-8}\end{array}$ & $\begin{array}{l}1 \times 10^{-2} \\
1 \times 10^{-2} \\
1 \times 10^{-4} \\
1 \times 10^{-4}\end{array}$ \\
\hline Rubidium (37) & $\backslash$ & $\begin{array}{l}R b-86 \\
R b-87\end{array}$ & $\begin{array}{l}5 \\
5 \\
5 \\
5\end{array}$ & $\begin{array}{l}1 \times 10^{-8} \\
2 \times 10^{-9} \\
2 \times 10^{-8} \\
2 \times 10^{-9}\end{array}$ & $\begin{array}{l}7 \times 10^{-5} \\
2 \times 10^{-5} \\
1 \times 10^{-4} \\
2 \times 10^{-4}\end{array}$ \\
\hline Ruthenium (44) & & $\begin{array}{l}R u-97 \\
R u-103 \\
R u-105 \\
R u-106\end{array}$ & $\begin{array}{l}5 \\
1 \\
5 \\
1 \\
5 \\
1 \\
5 \\
1\end{array}$ & $\begin{array}{l}8 \times 10^{-8} \\
6 \times 10^{-8} \\
2 \times 10^{-8} \\
3 \times 10^{-9} \\
2 \times 10^{-8} \\
2 \times 10^{-3} \\
3 \times 10^{-9} \\
2 \times 10^{-10}\end{array}$ & $\begin{array}{l}4 \times 10^{-4} \\
3 \times 10^{-4} \\
8 \times 10^{-5} \\
8 \times 10^{-5} \\
1 \times 10^{-4} \\
1 \times 10^{-4} \\
1 \times 10^{-5} \\
1 \times 10^{-5}\end{array}$ \\
\hline Samarium (62) & & $\begin{array}{l}5 m-147 \\
5 m-151 \\
5 m-153\end{array}$ & $\begin{array}{l}5 \\
1 \\
5 \\
1 \\
5 \\
1\end{array}$ & $\begin{array}{l}2 \times 10^{-12} \\
9 \times 10^{-12} \\
2 \times 10^{-9} \\
5 \times 10^{-9} \\
2 \times 10^{-8} \\
1 \times 10^{-8}\end{array}$ & $\begin{array}{l}6 \times 10^{-5} \\
7 \times 10^{-5} \\
4 \times 10^{-4} \\
4 \times 10^{-4} \\
8 \times 10^{-5} \\
8 \times 10^{-5}\end{array}$ \\
\hline Scandium (21) & & $\begin{array}{l}S c-46 \\
S c-47 \\
S c-48\end{array}$ & $\begin{array}{l}5 \\
1 \\
5 \\
1 \\
5\end{array}$ & $\begin{array}{l}8 \times 10^{-9} \\
8 \times 10^{-10} \\
2 \times 10^{-8} \\
2 \times 10^{-8} \\
6 \times 10^{-9} \\
5 \times 10^{-9}\end{array}$ & $\begin{array}{l}4 \times 10^{-5} \\
4 \times 10^{-5} \\
9 \times 10^{-5} \\
9 \times 10^{-5} \\
3 \times 10^{-5} \\
3 \times 10^{-5}\end{array}$ \\
\hline Selenium (34) & & Se- -75 & $\begin{array}{l}5 \\
l\end{array}$ & $\begin{array}{l}4 \times 10^{-8} \\
4 \times 10^{-9}\end{array}$ & $\begin{array}{l}3 \times 10^{-4} \\
3 \times 10^{-4}\end{array}$ \\
\hline Silicon (14) & & $5 i=3 i$ & $\begin{array}{l}5 \\
l\end{array}$ & $\begin{array}{l}2 \times 10^{-7} \\
3 \times 10^{-8}\end{array}$ & $\begin{array}{l}9 \times 10^{-4} \\
2 \times 10^{-4}\end{array}$ \\
\hline
\end{tabular}

(6-1.79)

10. Table 3 


\begin{tabular}{|c|c|c|c|c|}
\hline $\begin{array}{l}\text { Element } \\
\text { (a tomic } \\
\text { number) }\end{array}$ & Isotope & & $\begin{array}{l}\text { Column } 1 \\
\text { Air } \\
(\mu C i / m l)\end{array}$ & $\begin{array}{l}\text { Column II } \\
\text { Water } \\
(\mu \mathrm{C} / \mathrm{ml})\end{array}$ \\
\hline Siliver (47) & $\begin{array}{l}\mathrm{Ag}-105 \\
\mathrm{Ag}-110 \mathrm{~m} \\
\mathrm{Ag}-111\end{array}$ & $\begin{array}{l}5 \\
1 \\
5 \\
1 \\
5 \\
1 \\
1\end{array}$. & $\begin{array}{l}2 \times 10^{-8} \\
3 \times 10^{-9} \\
7 \times 10^{-9} \\
3 \times 10^{-10} \\
1 \times 10^{-8} \\
8 \times 10^{-9}\end{array}$ & $\begin{array}{l}1 \times 10^{-4} \\
1 \times 10^{-4} \\
3 \times 10^{-5} \\
3 \times 10^{-5} \\
4 \times 10^{-5} \\
4 \times 10^{-5}\end{array}$ \\
\hline Sodium (11) & $\begin{array}{l}\mathrm{Na}-22 \\
\mathrm{Na}-24\end{array}$ & $\begin{array}{l}5 \\
1 \\
5 \\
1\end{array}$ & $\begin{array}{l}6 \times 10^{-9} \\
3 \times 10^{-10} \\
4 \times 10^{-8} \\
5 \times 10^{-9}\end{array}$ & $\begin{array}{l}4 \times 10^{-5} \\
3 \times 10^{-5} \\
2 \times 10^{-4} \\
3 \times 10^{-5}\end{array}$ \\
\hline Strontium (38) & $\begin{array}{l}S r-85 m \\
S r-85 \\
S r-89 \\
S r-90 \\
S r-91 \\
S r-92 .\end{array}$ & $\begin{array}{l}5 \\
1 \\
5 \\
1 \\
5 \\
1 \\
5 \\
1 \\
5 \\
1 \\
5 \\
1\end{array}$ & $\begin{array}{l}1 \times 10^{-6} \\
1 \times 10^{-6} \\
8 \times 10^{-9} \\
4 \times 10^{-9} \\
3 \times 10^{-10} \\
1 \times 10^{-9} \\
3 \times 10^{-11} \\
2 \times 10^{-10} \\
2 \times 10^{-8} \\
9 \times 10^{-9} \\
2 \times 10^{-8} \\
1 \times 10^{-8}\end{array}$ & $\begin{array}{l}7 \times 10^{-3} \\
7 \times 10^{-3} \\
1 \times 10^{-4} \\
2 \times 10^{-4} \\
3 \times 10^{-6} \\
3 \times 10^{-5} \\
3 \times 10^{-7} \\
4 \times 10^{-5} \\
7 \times 10^{-5} \\
5 \times 10^{-5} \\
7 \times 10^{-5} \\
6 \times 10^{-5}\end{array}$ \\
\hline Sulfur (16) & $5-35$ & $\begin{array}{l}5 \\
1\end{array}$ & $\begin{array}{l}9 \times 10^{-9} \\
9 \times 10^{-9}\end{array}$ & $\begin{array}{l}6 \times 10^{-5} \\
3 \times 10^{-4}\end{array}$ \\
\hline Tantalum (73) & $T a-182$ & $\begin{array}{l}S \\
l\end{array}$ & $\begin{array}{l}1 \times 10^{-9} \\
7 \times 10^{-10}\end{array}$ & $\begin{array}{l}4 \times 10^{-5} \\
4 \times 10^{-5}\end{array}$ \\
\hline Technetium (43) & $\begin{array}{l}\text { Tc-96m } \\
T c-96 \\
T c-97 m \\
T c-97 \\
T c-99 m \\
T c-99\end{array}$ & $\begin{array}{l}5 \\
1 \\
5 \\
1 \\
5 \\
1 \\
5 \\
1 \\
5 \\
1 \\
5 \\
1\end{array}$ & $\begin{array}{l}3 \times 10^{-6} \\
1 \times 10^{-6} \\
2 \times 10^{-8} \\
8 \times 10^{-9} \\
8 \times 10^{-8} \\
5 \times 10^{-9} \\
4 \times 10^{-7} \\
1 \times 10^{-8} \\
1 \times 10^{-6} \\
5 \times 10^{-7} \\
7 \times 10^{-8} \\
2 \times 10^{-9}\end{array}$ & $\begin{array}{l}1 \times 10^{-2} \\
1 \times 10^{-2} \\
1 \times 10^{-4} \\
5 \times 10^{-5} \\
4 \times 10^{-4} \\
2 \times 10^{-4} \\
2 \times 10^{-3} \\
8 \times 10^{-4} \\
6 \times 10^{-3} \\
3 \times 10^{-3} \\
3 \times 10^{-4} \\
2 \times 10^{-4}\end{array}$ \\
\hline
\end{tabular}


ORECON ADMONTSTRATTVE RULES

CENPIE 36, DIVISION 50 - ENERGY FACIIIY STING COUNCA

\begin{tabular}{|c|c|c|c|}
\hline $\begin{array}{l}\text { Element } \\
\text { (atomic } \\
\text { number) }\end{array}$ & I sotopet & $\begin{array}{l}\text { Column i } \\
\text { Air } \\
\left({ }_{w C i / m l)}\right.\end{array}$ & $\begin{array}{l}\text { Column } 2 \\
\text { Water } \\
(\mu C i / m i)\end{array}$ \\
\hline Tellurium (52) & $\begin{array}{ll}T e-125 m & s \\
T e-127 m & 5 \\
T e-127 & 5 \\
& ! \\
T e-129 m & 5 \\
T e-129 & 5 \\
T e-131 m & 5 \\
T e-132 & 5 \\
& 1\end{array}$ & $\begin{array}{l}1 \times 10^{-8} \\
4 \times 10^{-9} \\
5 \times 10^{-9} \\
1 \times 10^{-9} \\
6 \times 10^{-8} \\
3 \times 10^{-8} \\
3 \times 10^{-9} \\
1 \times 10^{-9} \\
2 \times 10^{-7} \\
1 \times 10^{-7} \\
1 \times 10^{-8} \\
5 \times 10^{-9} \\
7 \times 10^{-9} \\
4 \times 10^{-9}\end{array}$ & $\begin{array}{l}2 \times 10^{-4} \\
1 \times 10^{-4} \\
6 \times 10^{-5} \\
5 \times 10^{-5} \\
3 \times 10^{-4} \\
2 \times 10^{-4} \\
3 \times 10^{-5} \\
2 \times 10^{-5} \\
8 \times 10^{-4} \\
8 \times 10^{-4} \\
6 \times 10^{-5} \\
4 \times 10^{-5} \\
3 \times 10^{-5} \\
2 \times 10^{-5}\end{array}$ \\
\hline Terbium (65) & Tb-160 $\quad s$ & $\begin{array}{l}3 \times 10^{-9} \\
1 \times 10^{-9}\end{array}$ & $\begin{array}{l}4 \times 10^{-5} \\
4 \times 10^{-5}\end{array}$ \\
\hline Thallium (81) & $\begin{array}{cc}T 1-200 & S \\
& l \\
T 1-201 & S \\
& I \\
T 1-202 & 5 \\
T 1-204 & 5 \\
1 & I\end{array}$ & $\begin{array}{l}9 \times 10^{-8} \\
4 \times 10^{-8} \\
7 \times 10^{-8} \\
3 \times 10^{-8} \\
3 \times 10^{-8} \\
8 \times 10^{-9} \\
2 \times 10^{-8} \\
9 \times 10^{-10}\end{array}$ & $\begin{array}{l}4 \times 10^{-4} \\
2 \times 10^{-4} \\
3 \times 10^{-4} \\
2 \times 10^{-4} \\
1 \times 10^{-4} \\
7 \times 10^{-5} \\
1 \times 10^{-4} \\
6 \times 10^{-5}\end{array}$ \\
\hline Thorium (90) & $\begin{array}{cc}\text { Th-227 } & 5 \\
& 1 \\
T h-228 & 5 \\
& 1 \\
T h-230 & 5 \\
& 1 \\
T h-231 & 5 \\
& 1 \\
T h-232 & 5 \\
& 1 \\
\text { Th-natural } & 5 \\
& 5 \\
\text { Th-234 } & 5 \\
& 5 \\
& 1\end{array}$ & $\begin{array}{l}1 \times 10^{-11} \\
6 \times 10^{-12} \\
3 \times 10^{-13} \\
2 \times 10^{-13} \\
8 \times 10^{-14} \\
3 \times 10^{-13} \\
5 \times 10^{-8} \\
4 \times 10^{-8} \\
1 \times 10^{-12} \\
1 \times 10^{-12} \\
2 \times 10^{-12} \\
2 \times 10^{-12} \\
2 \times 10^{-9} \\
1 \times 10^{-9}\end{array}$ & $\begin{array}{l}2 \times 10^{-5} \\
2 \times 10^{-5} \\
7 \times 10^{-6} \\
1 \times 10^{-5} \\
2 \times 10^{-5} \\
3 \times 10^{-5} \\
2 \times 10^{-4} \\
2 \times 10^{-4} \\
2 \times 10^{-6} \\
4 \times 10^{-5} \\
2 \times 10^{-5} \\
2 \times 10^{-5} \\
2 \times 10^{-5} \\
2 \times 10^{-5}\end{array}$ \\
\hline Thulium (69) & $T m=170 \mathrm{~s}$ & $\begin{array}{l}1 \times 10^{-9} \\
1 \times 10^{-9}\end{array}$ & $\begin{array}{l}5 \times 10^{-5} \\
5 \times 10^{-5}\end{array}$ \\
\hline
\end{tabular}

$(6-1-79)$

12 - Table 3 


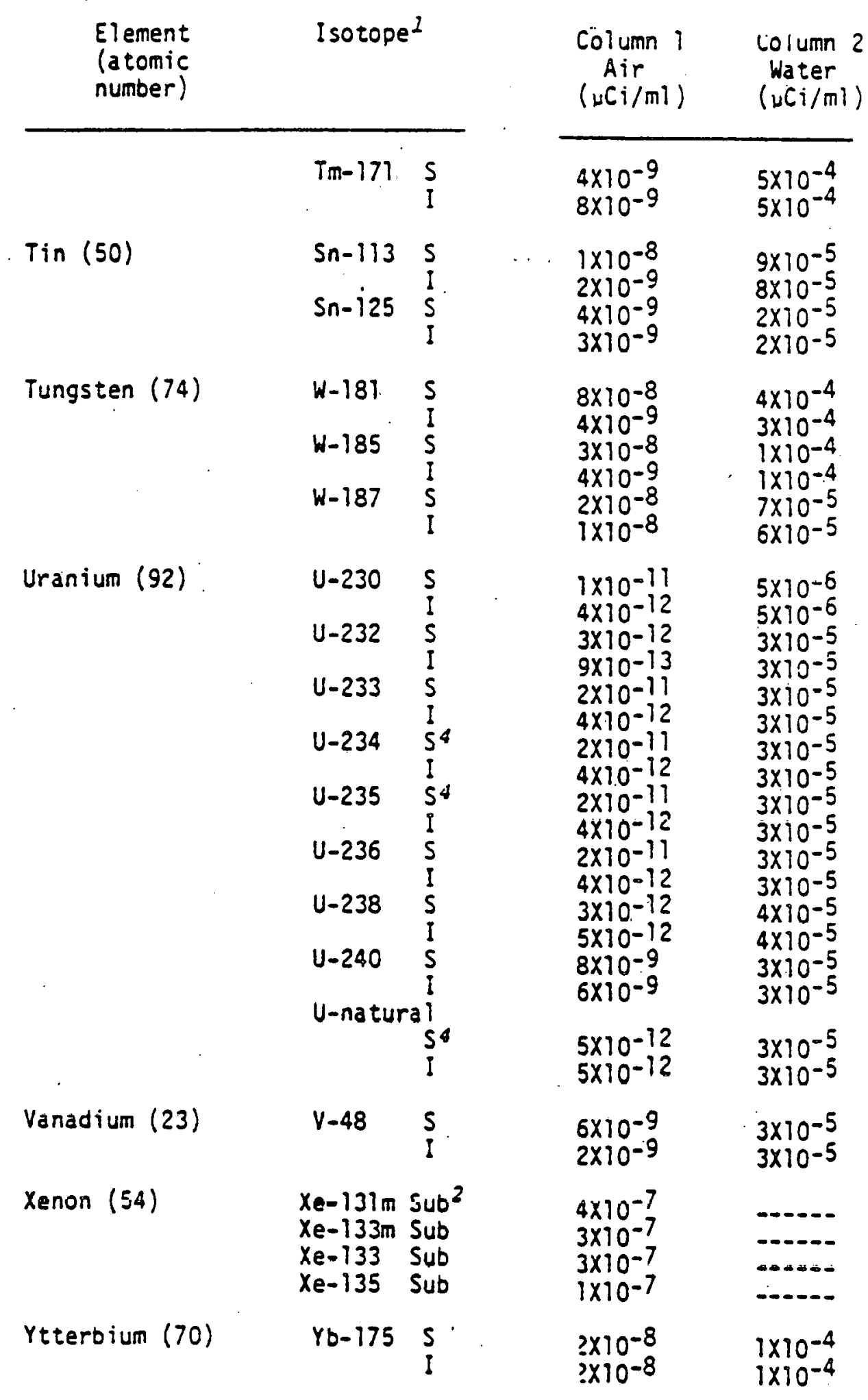




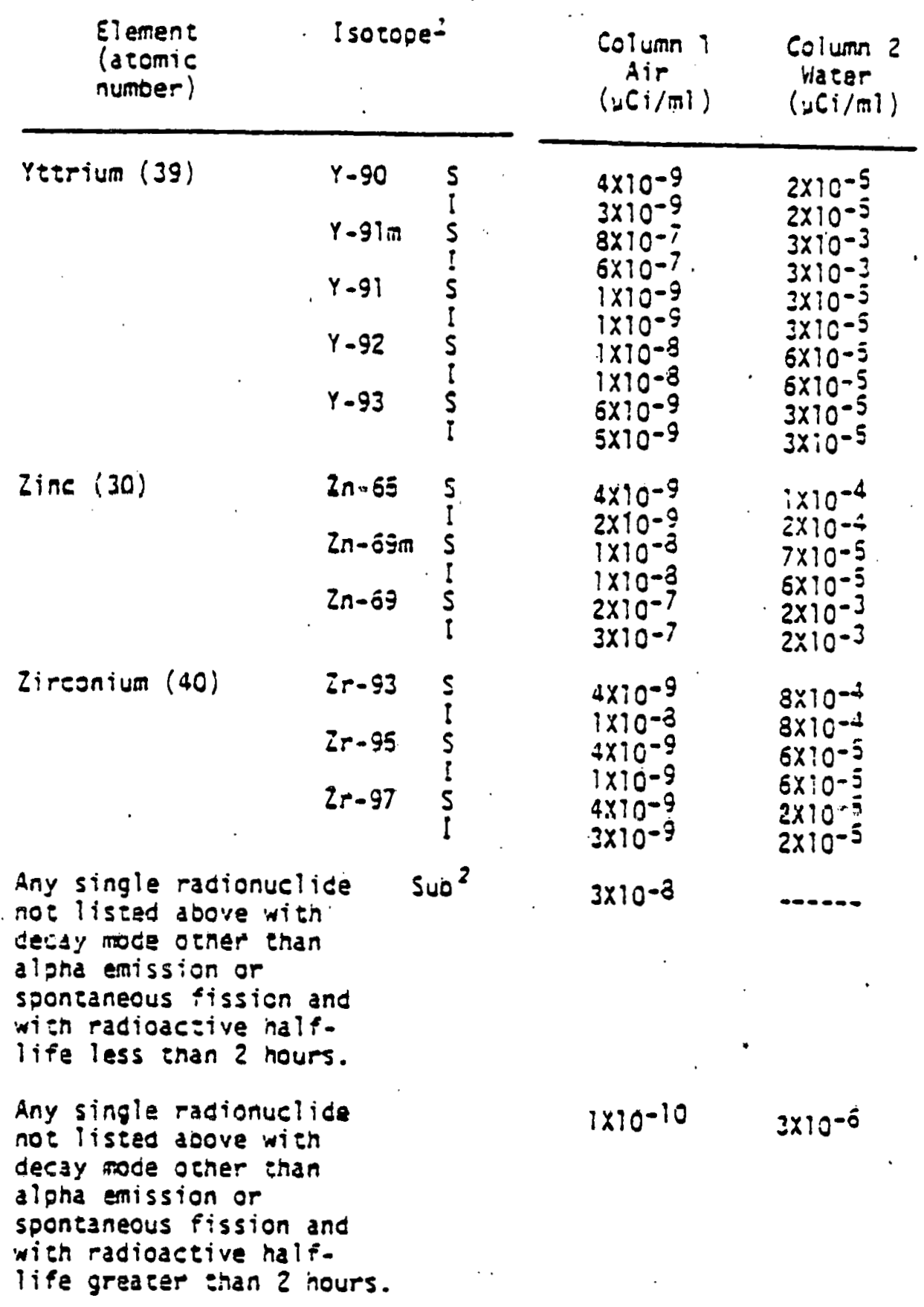




\begin{tabular}{|c|c|c|c|}
\hline $\begin{array}{l}\text { Element } \\
\text { (atomic } \\
\text { number) }\end{array}$ & Isotopel & $\begin{array}{l}\text { Column } 1 \\
\text { Air } \\
(u C i / m i)\end{array}$ & $\begin{array}{l}\text { Column } 2 \\
\text { Water } \\
(u C i / m l)\end{array}$ \\
\hline $\begin{array}{l}\text { ingle r } \\
\text { listed al } \\
\text { is by al } \\
\text { ontaneo }\end{array}$ & $\begin{array}{l}\text { de } \\
\text { ch } \\
\text { ion } \\
\text { n. }\end{array}$ & $2 \times 10^{-14}$ & $3 \times 10^{-8}$ \\
\hline
\end{tabular}

'Toluble (S); Insoluble (I).

2"Sub" means that values given are for submersion in a semi-spherical infinite cloud of airborne material.

3 These radon concentrations are appropriate for protection from radon-222 combined with its short-lived daughters. Alternatively, this value may be replaced by one-thirtieth (1/30) of a "working level". (A working level is defined as any combination of short-lived radon-222 daughters, poTonium-218, Tead-214, bismuth214, and polonium-214, in one liter of air, without regard to the degree of equilibrium, that will result in the ultimate enission of $1.3 \times 10^{5} \mathrm{MeV}$ of alpha particle energy.)

4 For soluble mixtures of U-238, U-234 and U-235 in air chemical toxicity may be the limiting factor. If the percent by weight (enrichment) of U-235 is less than 5 , the concentration value is 0.007 milligrams uranium per cubic meter of air. The specific activity for natural uranium is $6.77 \times 10^{-7}$ Curies per gram $U$. The specific activity for other mixtures of U-238, U-235 and U-234, if not known, shall be:

$$
\begin{array}{lll}
S A=3.6 \times 10^{-7} \text { Curies/gram } U & \\
S A=\left(0.4+0.38 E+0.0034 E^{2}\right)\left(10^{-6}\right) & \begin{array}{l}
\text { U-depleted } \\
E \geq 0.72
\end{array}
\end{array}
$$

where $E$ is the percentage by weight of $U-235$, expressed as percent. 
NOTE: In any case where there is a mixture in air or water of more than one radionuclide, the limiting values for purposes of this Appendix should he determined as follows:

. i. If the identity and concentration of each radionuclide in the mixture are known, the limiting values should be derived as follows: Determine, for each radionuclide in the mixture, the ratio between the quantitv oresent in the mixture and the limit otherwise established in Taole III for the specific radionuclide when not in a mixture. The sum of suen ratios for all the racionuclides in the mixture may not exceed "l" (i.e., "unity").

Example: If radionuclides $a, b$ and $c$ are present in concentrations

$C_{a}, C_{b}$ and $C_{c}$. and if the applicable MPC!s are MPC $C_{3}, M P C_{b}$ and $M P C_{c}$ respectively, then the concentrations shali be limited so that the following relationship exists:

$$
\frac{C_{a}}{M P C_{a}}+\frac{C_{b}}{M P C_{b}}+\frac{C_{c}}{M P C_{c}} \leq 1
$$

2. If either the identity or the concentration of any radionuclide in the mixture is not known, the limiting values for purposes of :Table III shall be:

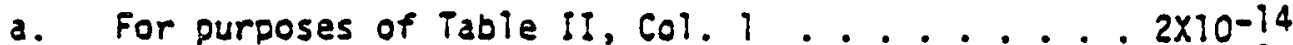
b. For purposes of Tabie II, Col. 2 ............... $3 \times 10^{-8}$

3. If any of the condt tyons specified below are met, the corresponding values spectified below may be used in lieu of those specified in paragraph 2 atove.

a. If the identity of each radionuclide in the mixture is known but the concentration of one or more of the radionuclides in the mixture is not known, the concentration limit for the mixture is the limit specified in Table III for the radionuclide in the mixture having the lowest concentration limit; or

b. If the identity of each radionuclide in the mixture is not known, but it is known that certain radionuclides specified in. Table III 'are not present in the mixture, the concentration limit for tne mixture is the lowest concentration limit specified in Table III for any radionuclide which is not known to be absent from the mixture; or 
c. Radionuclide

If it is known that $5 r-90, !-125$, I-126, I-129, I-131, (I-133 Table II only), $\mathrm{Pb}-210, \mathrm{PO}_{\mathrm{O}} 210$, At-211, Ra-223, Ra-224, Ra-226, Ac-227, $\mathrm{Ra}-228, \mathrm{Th}-230, \mathrm{~Pa}-231$, Th-232, Th-nat, Cm-248, Cf -254 and $F_{m-256}$ are not present

If it is known that $5 r-90,1-125$, I-126, I-129, (1-131, I-133, Table II only), Pb-210, Po-210, $\mathrm{Ra}-223, \mathrm{Ra}-226, \mathrm{Ra}-228, \mathrm{~Pa}-231$, Th-nat, Cm-248, Cf -254 and

Fm-256 are not present ............

If it is known that $5 r-90,1-129$, (1-125, I-126, I-131, Table II oniy), Pb-210, Ra-226, Ra-228, $\mathrm{Cm}-248$ and $\mathrm{Cf}-254$ are not

present -..--

If it is known that (1-129, Table II only), Ra-226 and Ra-228 are not present -..........................

If it is known that alpha-emitters and $\mathrm{Sr}-90, I-129, \mathrm{~Pb}-210, \mathrm{Ac}-227$,

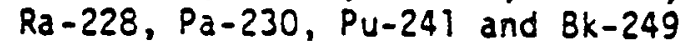
are not present ......................

If it is known that alpha-emitters and Pb-270, Ac-227, Ra-228 and

Pu-241 are not present

If it is known that alpha-emitters and $A C-227$ are not present .....

If it is known that Ac-227, Th-230, $\mathrm{Pa}-231, \mathrm{Pu}_{\mathrm{-}} 238, \mathrm{Pu}_{\mathrm{u}} 239, \mathrm{Pu}-240$, Pu-242, Pu-244, Cm-248, Cf-249 and $C f-251$ are not present ......

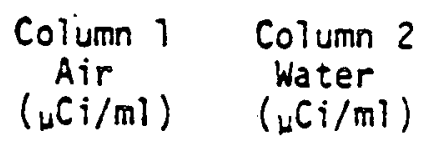

Air water

-... $3 \times 10^{-6}$

… $\quad 2 \times 10^{-6}$

$6 \times 10^{-7}$

$1 \times 10^{-7}$

$1 \times 10-10$

$1 \times 10^{-11}$

$1 \times 10^{-12}$

$1 \times 10^{-13}$ 
4. If the mixture of radionuclides consists of uranium and its daughter products in ore dust prior to chemical processing of the uranium ore, the values specified below may be used in lieu of those determined in accordance with paragraph 1 above or those specified in paragraphs 2 and 3 above.

For purposes of Table II! Colum 1, $3 \times 10^{-12} \mathrm{uCi} / \mathrm{ml}$ gross alpha activity; $2 \times 10^{-12}$ uCi/mi natural uranium; or 3 micrograms per cubic meter of air natural uranium.

5. For purposes of this note, a radionuclide may be considered as not present in a mixture if (a) the ratio of the concentration of that radionuclide in the mixture (C) to the concentration limit for that radionuclide specified in Table III ( $M \mathrm{PC}_{a}$ ) does not exceed $1 / 10$, (i.e., considered as not present in the mixture does not exceed $1 / 4,\left(i . e,, C_{a} / M P C_{a}+C_{b} / M P C_{b}+\ldots . . \leq 1 / 4\right)$. 


\section{DIVISTON CO}

\section{TRANSFORTATION OF \\ RADIOACIIVE MATIRIAL}

\section{Desinitions}

345-60-001 For purpose of ORS 453.535 and as used in these rules:

(1) "Nuclear reactor fission products" means a mixcure of radio-nuclides formed as a result of fission in a nuclear reactor. These fission protuces are norwally present in spent nuclear fuel, radioactive wastes resulting trom thel reprocessing, and redioactive waste accumulated in the course of operation of nuclear reactor waste prearment systems.

(2) "Shipper" mpans a site certificate boldex or other person oripinsting a shipment of melent renctor fission products destined to move within or through the Sores of Oregon.

Ser Aunt: ORS O.

Eix: NTEC 7, 1, 2-20-74, $4,3-11-74$

Apptenbilty and Scope

345-60-003 (1) These rules apply to the shipment of nuclear reactor fission products, in quantities preater than 10,000 curies, within or through the State of Oregon.

(2) Shipmeats made by or under the diroction of the U.S. Atomic Energy Commission or the Department of Defense. and which are escorted by personnel designated by or under die autiviliy of those agticites, tor the purpose of mocional security, are exempt from these rules.

(3) These rules are in adtition w yplicable rules and regulations of the United Stotes Department of Tranaportation and the United States Atomic Energy Commission.

Stan Auth: ORS Ch

ET: NTEC 7, $1.2-20-74$, \&. 3-11.74

\section{Nottication}

34560 ous (1) All shipments as defined in rule 34560 003 (1), ocher than those exempted by rule 345-60-003(2), shill require prior notification to the Energy Fraitity Siting Counci. addressed to Office of the Coondinator. Oregon Enery Facility Siting Council, Salem, Oregon 97310 . Notifieation may be provided by either the shipper or the carrier. However, it shnil be the carrier's responsibility to assure the required Dotification has been provided. This ootification sball be made by telegram or registered mail at least Eve days, not inclucting Samudays, Suriays, and bolidays, prior to stipment. The nocification shall include the following information:

(a) Name and address of shipper, currier, and consingee;

(b) Mode of transport;

(c) Type, quantity and form of radiosctive material in each package, and the toeal quantity in the shiponent;

(d) Description of the packaging, including amount asd compocition of any coolant, and applicable DOT container permit number:

(e) Identification numbers of tucks (both tractor and trailer identification) or trains (both trin and spocific ail ar ideatifietion) being unized in the shipmeat. It is recoginized that in some cases specitic identification of tractor, troiler, or mil ars my not be possible. In this event the most complete identification precticable shall be furnished.

(A) Date or dutes of movement within Oregea and routes to be followed.

(2) In the event that revisions in the information required by (IXa) through ( $($ ) above oceur subsequent to the required notification, the revised information shall be inomediately provided by telephone to the Otfice of the Coordinator. Enery Fraility Siting Council.

(3) The Energy Facility Siting Council may, through any authorized reprosentntivo, decigonto routes, bours of trauspur $L$, check points on route, or other safety precaurions for shipments requiting nocification under thoes riles.

Ste Anth: ORS Ch.

Bic NTBC 7, 1.2-20-74, \&. 3-11-74

\section{Impectom}

$346-6007$ Shipments requiring potification under these nules may be inspected by the Energy Facility Siting Council. through any whorized representative, for compliance with applicable rules and regulations.

Stat Airen: ORS OS.

BIE: NTEC 7, \{. 2-20-74, \&. 3-11-74 


\section{APPENDIX $C$ \\ REPRESENTATIVE LOCAL NEWSPAPER ARTICLES \\ RELATED TO RADIATION ISSUES AND \\ RADIOACTIVE WASTE MANAGEMENT}

C-1 


\section{N-plant hearings opened to press}

\section{By PALL MANIEY}

\section{Journul Staft Wrtter}

Oregon's Energy Facility Siting Council decided Friday to follow a middle course in cpen vs. closed deliberations leading to a decision approving or blocking construction of the proposed Pebble Springs nuclear complex in Eastern Oregon.

Urged on one hand to hold all discus. sions in public and warned on the other that open arguments may provoke emotional outbursts or disruptive actions by the public, the council voted 5 to 1 to allow news reporters to uituess all delib. erations. whether in open or closed ses. sloas, with the possible exception of those Involving security-sensitive matters.

In debate at the council's monthly meetdug in Portland Friday, most of the six members present expressed a prefer. ence for holding most dellberating sessions in public.

The lone disseating vote on the adopted plan was cast by Dawa Dresster, who said she would have preferrad a policy calling for all dellberadous is public except possibly those favolving auclear security.

The seven-member coundl expects to begin within the next month a sertes of discussions of testimony and evidence pre seated at a hearing that spanned more than a year on the pros and cons of building the proposed $\$ 3.5$ billion nuclear power plants just south of Artington in Gilliam County.

Henrings Officer Lowell Bergen las month gave the council his recommenda. tions on some of the subjects on which testimony was required Among these are plant security, the alleged aeed for electridty to be geatrated by the twio plints and the financial ability of the sponsors to buld and operate the plants and uitimateIy decommisstion them.

Bargen found that the spunsurs falled to meet Siting Council standards relating to effects of energy conservation, training for emergency decistons, ecohomic pru. dence and plant security, but the council is free to disagree with his conclusions.

Sponsors of the two proposed 1,200megawatt powar plants are Portland Generd Electric Co., Pacific Power L Light Co. Puget Sound Power \& Light Co. and a group of Oregon electitc cooperatives un. der the bunner of Pacific Northwert Genertdan $\mathrm{Co}$.

Sidng Council mambers astreed Priday to start their deliberations with those sec. tions of Bergen's recommendations that are not challenged by any parties to the hearing. "to get our feet wes," is one member phrased it.

Next, they will tuke up the "lenst can. trovertal" sectlons of Bergen's findings that are challenged, and finully those that ellett the and stverse comment.

Objections to peres of Bergen's IIndings buve been praseated to the council by the projoet's sponsors and by Lloyd Marbet and Carl Freedmen of the environmental group called Forelaws On Bourd, who repreanted the poblic interest in the hearing

Murbet and Freedman both expressed direngy at tho conncl's dectrios to permit cloand deliberstions on any subject, and

PGE Vlce President and Ceneral Counsel James W. Durham, a former deputy attor: ney general. urged rouncil mombers to hoid as many dellberations in public as possible.
Brother Raphael Wlison, one of three new members named to the council this year, remarked that. "It's arr' goal to as. sure a good quality decision" an whether the nuclear project should be built, and added that there would be times when be would want to reflect calmiy on the evi: dence, indicating that the prospect of public disruptions might interfere.

Siting Council Chnirma Water Evạ: a Portland Lwyer, and Ardenat Aromey General Richard Sandvit rembodod cots: cil members that Oregon's administrative procedures rules give them discresion to decide whether their deliberations witl be in open or closed sessions.

Coundl Member Marian Frank anid she fett it would be "a serious miscake" not to deliberate in public.

While the council debates Berges's ind. tial recommendations, hurther serdions of the stace's Pebble Springs tearing are plunted to consider disposal of radionctive wares irom the project and the effect of last spring's Tbree Mtle Irisad anclear plent ralshap in Penasylvania.

The councll Friday authorized Sucan Garrett of Steridan io help represent the public Interest, together with Mirbet and Freedmen, is fuare ections of the bear. Ias.

Mss Girrett, who holds a law depere pardicipated lest year in tederil hearites opposing a proposel io expand the Trojes - nuclear power plant's capacty to store spent radionctive fuel at the plunt dto is Columbia Copinty.

The Pebble Sprincs project reeds tedtes at is well is tate perides before cop. crivedoe can byda. 


\section{Ballot on N-plants challenged}

MOUNT VERNON, Wash. (UPI) - PUget Sound Power \& Light Co. has ftled hewsult challedging the Skagit cousty Commlsatos's decision to place on the Nov. 6 ballot a proposition eababling residents a vote on whether they support proposed construction of twin nuciear resctors on the Skagjt River near Sedro Wooley.
The proposituon is purely in edviery ballot, ensbing Skagit County voters to volce approval or disapproved of the pro. poced nuclear facillities.

Two Portland-based electric utillites are co-spousors of the proposed auclenr plante. Portand General Electric Co: owns a 30 percent share of the project and Padfic Power \& Ught Co. a 20 percent share.

Puget Power's out seeks to halt plece ment of the nuclear advisory measure on the bellot, sald Pager Power attorney Rerl Angevise. If that's not poselble, he satd. the company wants the ballors impounded until a deciston on the aviclear plase is made by the county commission.

Filed in Supertor Court, the sut clnimed

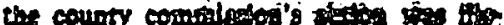

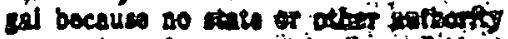

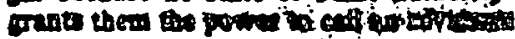
clector.

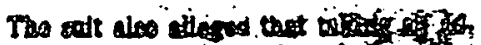

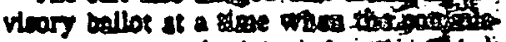

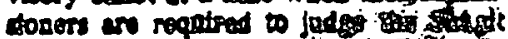

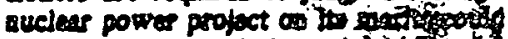

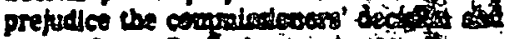

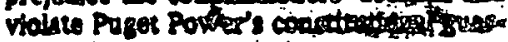
antes of the poceen.

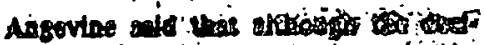

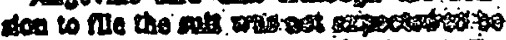

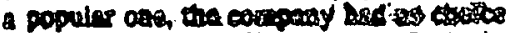

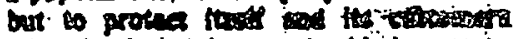

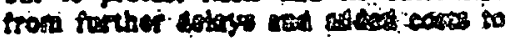

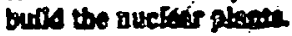




\section{jack anderson N-probe is shocking}

WASHEVTON - A all-eecret report by a predidentially appointed blue-ribbon comminaton Invesed gatias the nuclear die exter at the Taree Mille hined povier plent near Harribury, PL, is wand to throw Dew fat in the firetight ragins between proponents and enomies of nuclear power devet opment.

Antl-noke protesters, wch is those who ro cently stormed the bar. ' ricades of the Seabrook. N.H., nuclear faclitity. bave ande it clear they don't iatend to forget the cenr-catastrophic tiasco at Three Mile Island,

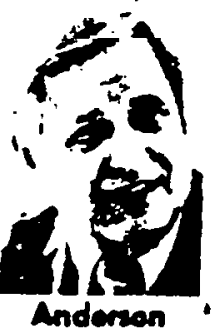
which held the entire nation in frightened surpense for six days laat March.

Nuclear power's stauachest defeaders. including Jimmy Carter, have attempted to soft-pedal the health and safety hazards of buliding more nuciear power plents. But the highly confidential fiadings of the presidential commission, hesded by Darmouth president Joho Kemeay, prove that Americans woro fortunate that the Three Mile Island aceldent wasn't worse, or didn't happen sooner.

Kemeny and his fellaw commissioners will report to the White House later this moath. But we've had access to their proIiminary eyes-only concludons, which are certala to change the way the auclear Indurtry is regulated.

Bustcally, what the investigators found was that at least at Three Mile Island, the auclear power industry is being rim by people who doa't know what they're doins - or don't care. Here are fust a few of the shocklag deflciencles the Kemeny Commisolon's invesdgators turned up:

- The Three Mlle Island fiasco was caused primarily by the inability of the operators, engineers and plant supervisors to recognize the mechanical faibure when It occurred. "This demonstrated a lack of fundameatal understanding of the plant destga and operational chnracteristics under normal and aboormal conditions," say the secret fladings.
- Qualifications for licensed nuclear plant personnel are incredibly lax. There are no minimum requirements on education or psychological fitness for reactor operatero; rupervisers and plaut tuausge!s - whose expertise and state of mind can mead the difference between safery and nightmere for millionds. Oas Nuclear Roguatory Commission official recalled ijcendng an individial who didn't have a high school education. Incredibly. there's oot even a requir:ment that applicants with criminal recorts be screened out.

- Training probrams are nun by the udlities with virtuslly no supervision by the NRC. The pregians run by the firm that designed Three Mile Island's reactors. for example, hayen'? beeo audited since 1968. and that audit dida't evaluate the coatents of the program. for the exam

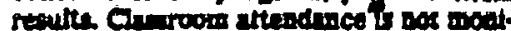
tored by the NRC. Files of pact NRC H. censtar exans are kept by the utlittes an ruldes for trulnees, one Kemeny comrais. doner told our reparter Christoph See cheoyl.

The realibot picture is one of tainias programs of which the NRC is lupgely isnorent. followed by examinations which are routinely passed without meaningful evaluatdon." coscluded the commission's suff lovedientors.

- The indurtry and the regulatory commistos falled to beed the warnings implicit in earlier accideats, both in this country and abroed, yet a pattera of probablity was clearly disceraible. For exampie, an aceldent - strilar to Three Mile lelend's, but less resious - occurred in 1974 at a auclear power plant in Bezanu. Switzerland, Involving American-made equipment. But the incident was never reported to the NRC, because the law requiring American firms to report reactorrolated accideats wasn't passed till two moethe hater.

Evea now, under mutual intormation soreemeats with 18 antions, the latarms. Hon the NRC sets trom overseas is ofteo "well laundered" to minimize seriousness, cecording to an NRC offidal.
- Wamings from knowledgeable, conseieatfous inspectors and sclentsists are shrugeed off by those with the power to correct potentially dangerous situations. NRe inupecior James Cressweil, sor ex. ample, tried in vatn for two years to get his supertors to do something about deff. etoneter at the David Besae ouelear plant Dear Toledo, Ohio - sbortcorrings that foreshadowed Three Mlle Island. And a Tenneacee Valley Authority scientist had opotted a major safety problem related to the salfunction that oceurred at TMI but hils informattoo was last in the shuffle untal after the auclear mishap that shook the world.

- Poor desiga made some vital infor. matlon in the reactor room insccessible. Malfunctionigg equiprent was slow to be removed or repalred, and Three Mile ts land magagement was lax in modl?ying operations and emergeacy procedures. "One unst conclude," the repor states. bluntly. "that the oversight of both the utlity and the NRC was clearly deficient in permitung these deficiencies to go unsttended."

Kemeny's probers, curiousiy, wrote off the heslit barard to those exposed to Three Mlle Isiand's radloactive tallout with the phrase "probably so detectable lonz-term delayed health effects." Aad it notes that "only three workers ... were exposed to sllghtly higher radiation dosen than constdered safe, but even those doset were not sufficieat to cause any scute lapury."

Yot the Investigators admitted that celantate are uncertain about the loag. torm affects of low-level radiation. 


\section{$\mathrm{N}$-plant poses no danger}

PLATTEVILLE, Colo. (UPI) - A preliminary la. vestigation Iadicates do measurable radiation es. caped during an equipmeat failure that shut down the Forr St. Vrain nuclear geterating plant for the third time in less than two years. A federal inspector sadd Monday.

"The plant already is back in stable condition," sald Mayaard Dickerson. the oa-site U.S. Nuclear Regulatory Commission inspector asstgned to the plant 40 miles east of Denver. He also sald no full scale NRC investigation is planned:
Dickerson said the shutdown occurted at $7 \mathrm{~km}$. Sunday wben belium, the primary coolant used at the fecillty, seeped into a beckup water system, sppareatly throegh a. wat. functoning valve.

"It's just a matter of fizIng valve. The plant could be operational agnin as 8000 as Tuesday after I complete an inspection of repalrs," Dickercon sajd
Moadey.

It was the thind storidown of the plant in then two years due to equipment fallure and tie recoed revultiag from a be lum strinlator : maltunetion.

Fort St. Vrain. wifigh opeod. is 1976, Is the teot nuelear power plane bujlt In Colorado. It employs a high-temperature, ges:cooled reactor. 
$\left[\begin{array}{l}n \\ 3\end{array}\right.$

Oregon Journal

Portland, Oregon

October 16, 1979

\section{$5 \mathrm{~N}$-foes occupy Atiyeh's office}

SAInA - After the ar. rex of tour andi-quelen protesters Monday; IV thare began what they sald would be 1 day-long camp out in Gov. VIc Atjyeb's of

Hce Tuesday, repeating

theit demands that the

Trojan auclear power plant in Raivier be shut down permenedtly.

The proteters, members of the Troing Decommisdoning Allance, sat in the coverwor's ceremonial office and talked with to portes is a plainclothes state trooper looked on from scrost the room.

Atyeh did not immed. tely emerge from his lo. ner office to talk with pro. tewan or reporters, but press secrotary Bebay Mlas ald, "The sovernor will mike on effort to talk to them somedme todny, If they are willing to watt."

Asted what the governor wes doing at the mo ment, Mlles replied, "He's entching up on spending two weeks out of the conntry (a Fur East tande mitcton)."

One of the protesters. James Mase of Portland. sild. WWe will oot leave
Cov. Atyet's ofile voluntarlly unies he orders an immodlate, permaneat deledvios of Trofto." 
Oregon statesman

Salem, Oregon

October 16, 1979

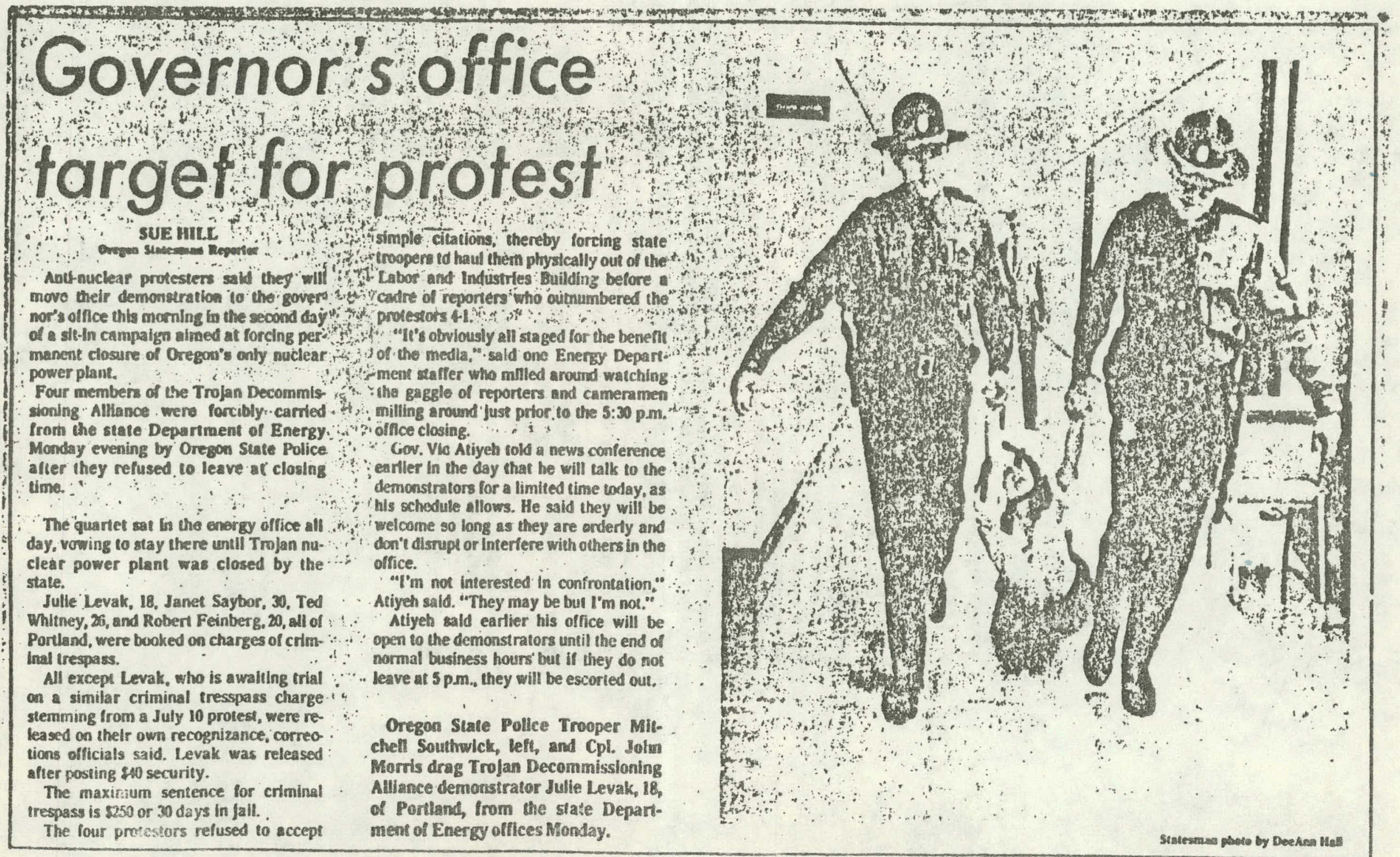



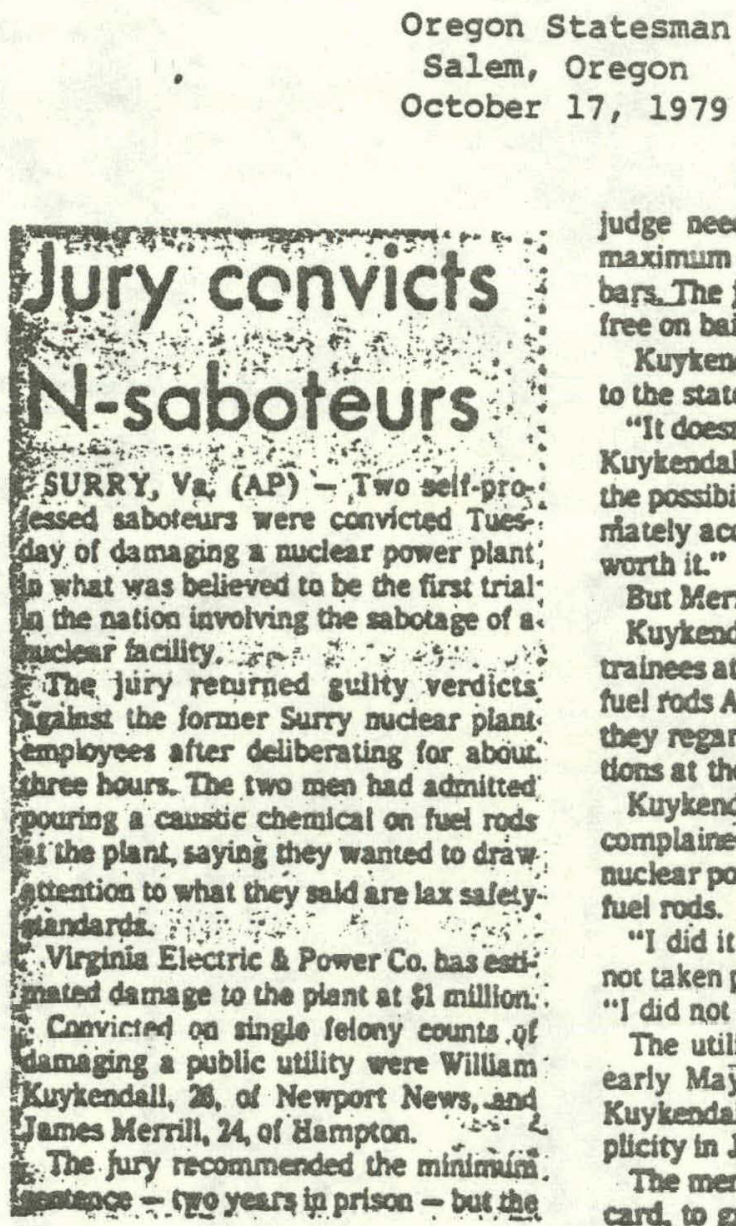

judge seed not accept the jury recommendation. The maximum sentence for the offense is 10 years behind bars. The judge set sentencing for Nov. 27 . Both men are iree on bail.

Kuytendall and Merrill plan to appeal the convictions to the state Supreme Court.

"It doesa't and bere. I have faith in the justice system." Kuytreadall said. Asked if damaging the plant was worth the possibility of going to prison, he responded" "Il it ulti. rinately accomplishes my objective, yes, it will have been worth it."

But Herrill said, "No, at least I don't think so."

Kuytendall and Merrill, former control room operator trainees at the ruclear plant, admitted they sabotaged the hel rods April 27. They said they did so to dramatize what they regarded as lex security and unsafe worting condidons at the plant.

Kuykendall and Merrill testified Monday that they had complaind in vain to the company abuut conditions at the nuclear power plant before deciding (1) damage the siort hel rods.

"I did it to shock my employer into action that he had not taken previously on his nwn accord." said Kuỵkendall "I did not want to hur anynne

The utility discovered the damage to the fuel rods in early May and began a search for the saboteurs. But Kuykendall and Merrill came forward to admit their complicity in June, belore an arrest was made.

The men had used Kurytrendall's "ley," coded plastic card, to gain sccess to a trid storage building, separate trum the auclear contatnment building.

- They carried tive galloes of sodium hycroxide into the resuricted area, and Kuykendall suid later that a security guard bad walked through the area while they were abo. aging the nods - 
Oregon Journal

Portl and, Oregon

October 24, 1979

\section{'It can happen here,' Trojan warned}

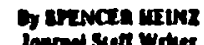

Maimien - nue lecomal Nuclear Rego-

Litory Comminton lone locel governameal

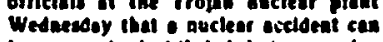

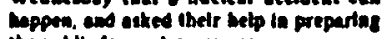

public for auch ad emergeacy.

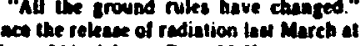

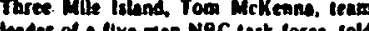

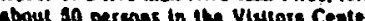

asdilortum at ine Troven plaal. "You've

cot to have a felli bas of iricte 10 protect ine public es best you cas."

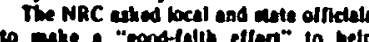

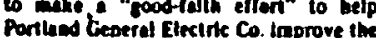

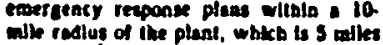
couth of Riviler.

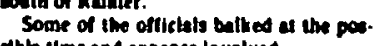
Ous ine $A$ expence iavalued

made oware that the tlies response in murkear actident chould be to iake Im. all furither inaruciloas.

The NAC lote offirlels that the porbly within 10 miles of ithe plant thouts be

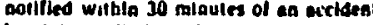
Invciving radlutilun release

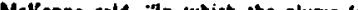

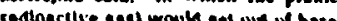

\section{blow down the triver so tan you woultory}

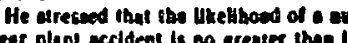

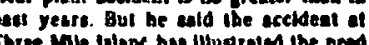

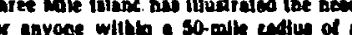

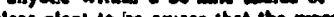

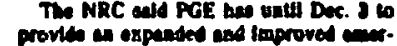

\section{Weld faults stall Hanford N-plant}

RIIIILAND, Warh. (UPI) - Repals derective wetho we meld

work woo't befls for al keast a mooth on

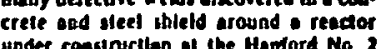
under consinsclitan at the Hardord Na. 2

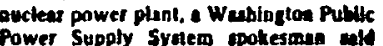

Wedsesday. on the t,0no-tan chlele ere -visully de

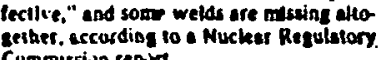

The etecto a musins ago. betre been ine largel of: lears of engineers attempllag to develop: plas of aclioo to repalr ithem, meld WPPS upply ayutem ingloeers are findablag the

Melly deagerous cartihquate favilt coule

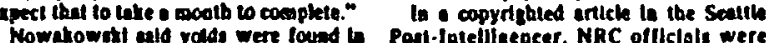

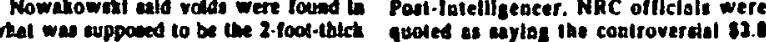

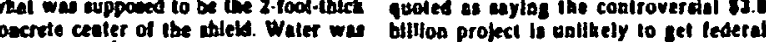

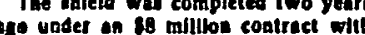
Lexinby Ca of seatike The lor. 10 expected to bedie operellog to - Shagll Coualy Supertur Court puate de

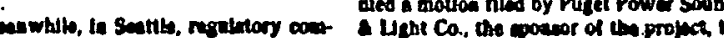

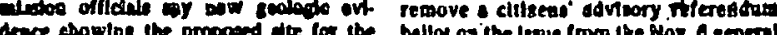

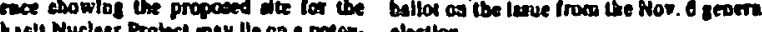

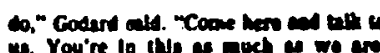

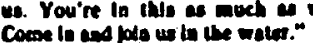
Mckean aid its entades ondropy

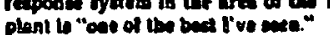

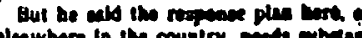
ilsel lraproverameat.

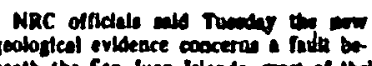

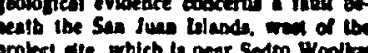

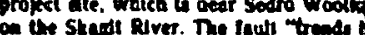

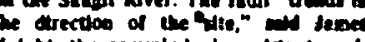

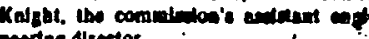
metriaz diretor.

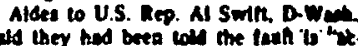

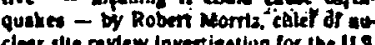
Cear slie reveW Invertigetluon for the U.S.

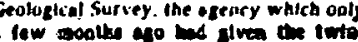

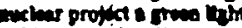

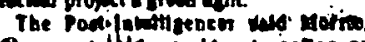

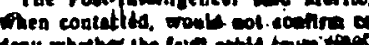
are.

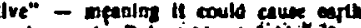




\section{Need for N-power stressed in drive}

A madonoride campaign in lavor of mucleas power atred Thursday, according to members of Noclear En. ergy Eduation Day (NEED).

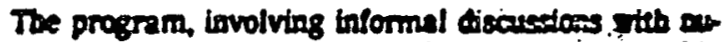
cleap industry spokernes across the US, is pousoned th Oregan by Oregan Women's League, Nuclear Evergy Wumbn and Women and Energy.

"Nuclear power is a highty misundersood, vmecesar.

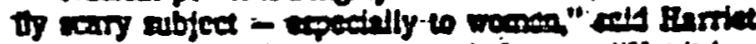
Beers. president of Oregon Women's League "Yet it a a

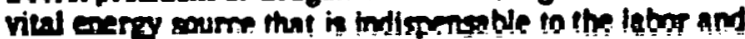

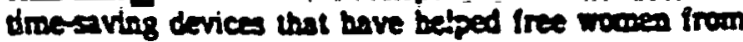
busebold chores."

More Information is available from Beers, of Beaver. ion, exogere 
Oregon Journal

Portland, Oregon

October 19, 1979

\section{Nuclear true confessions}

After Three Mile Island, what?

The electric utility industry's inswers to that question, outlined at a press conference sponsored by Portland General Electric Co. this week, make excellent sense, at least s tar as they 80.

One only wonders why the steps had not been taken long ago.

After the accident last March 28, when the nuclear power reactor at Three Mile Island near Harrisburg. $\mathrm{Pa}$., threatened to run out of control, the electric power industry formed a committee to study what lessons should be learned from it.

$\because$ The main recommendation so thr, as described at the meeting presided over by PGE's board chairman, Frank M. Warren, this week, iv creation of an Institute of Nuclear Power Operations (INPO). It will be rin by the operators of nuclear power plants, public and private. Its ob will be to develop and if possibie to enforce "benchmarks of ex. cellence" for the operatton of those piants.

Today there is "a wide disparity in the quality of operation" of nuclear plants, said A. J. Phister. general manager of the Salt River mclear project in Arizona, one of the participants in the industry's post-mortem to Three Mile Island.

The institute, which is scheduled to be in business by early aext year, will train and test the employees who operate nuclear plants, and the executives who hire and supervise them.

It will record and analyze the relatively little things that 80 wrong in nuclear plants, to try to see that they don't build up into major accidents. It will share information among nuclear operators worldwide.

It will audit the operation of each nuclear plant periodically, to see that it is meeting the best available standards.

It will maintain a national inventory of experts and special equipment. ready to rush them to the scene of a nuclear accident.

What? Haven't these things been done right along? No, said Warren and his colleagues.

In addition to forming INPO, the Industry is talking of organizing an insurance pool. It would help the power system which might suffer a prolonged outage from damage to a nuclear plant to pay for the replacement power it would need until the plant could be put back in service. Without such help, the local ratepayers bave to pay the whole cost. and in the case of PGE's Trojan plant, that cost runs $\$ 700,000$ to $\$ 900,000$ a day, Warten said.

By implication, the lasurance is a weapon INPO would use to force Individual utilities to maintain high standards: Get sloppy, and you're out of the pool.

Some of the lessons of Three Mlle Island, as recited by Warren and his colleagues, must be bitter for the industry - and they should be for the oublic as well:

- The Industry needs an indepen. deat source of technical informaton, separate from the manufactur. ers who sell the utilities their nuclear equipmeat. of course! Didn't anyone think of that before?

- The industry was wrong in thinking that if it did everything the federal Nuclear Regulatory Commission told it to do, it had done all it needed do. What an indictment of the federal regulators who, the public thought, were assuring the safety of nuclear plants!

A glaring omission from the plans for INPO are that it is not presently programmed to help find a way to dispose safely of the radioactive wastes a nuclear plant produces. This failure, which the federal government also shares, will remain the Achilles heel of the aucles industry until it is solved.

Traumatic as it was, Three Mile Island could have its beneficial side if it does awaken the industry and the public to such reforms as War. ren and his assoctates have described. We need the energy that nuclear piants can provide.

But why has the barn door been lett open so long? 


\section{N-medicine hurt by dump closure}

CARSON CITY, Ner. (UPI) - The clo eure of a auclear waste dump is Southern Neved could force thousads of boupitals, resenrch centers and lodurtries ceroes the andion to stockpile thetr own ridlonctlve materials, apokesmas for Cov. Robert Lint said Tuesdiy.

This is definitely courethiog that will

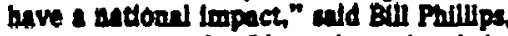
owe exeretury for List, who ordered the burtal grounde in Bunty ciosed becaure of efety violatton.

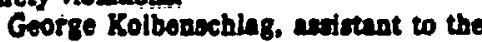
prestuent of Neclear Engineerias Co.n of Louiovillo, KY, whlah operited the dump. aid the shutdown could limit rech thing a future cancer reaearch. metallurgteal wort and bospital trentwent. He ald privete ledurtites don't bave the fecillides to store thetr own wastes. This is i nutjoad problem." cald Kolberintilas.

The 12000-nember Soclety of Nuclear Medicine, baned in Now York City, atked Lit to llow radlonetive materials from bontols and hboratortes to conthue to be burfed at Beatty ustil a clterantive the ens be lound The closure. sald Dr. Loard Pretrina, codety preddeah of
New York City, "crentes an immediate crits for anclent medicine and for thou. cands of Amertcans who seed its vital covices."

The entul closure wes supposed to be Tuesday but war detayed until Wednesdiy to allow trueke alluady en roure with the weste to dispose of it. There are only three commerclal burtal grounds in the intion - at Beatty, in Hinford, Wash. and Berawell. S.C.

Werbingtoa Gov. Dixy Lee Ray ba ituspeaded opertion in her state because im. properly peckeged waste was belug trins. purted to the sile. And South Carolina has ilinited the anount of radionctive materats It will sccept.

Lat, described as "very irstated" at the recent developments in Beatty, ordered the ourpension of the license of Nucleas Euguedting. Llat moved last moath to rovote the license permanently, but a bearins on thit action before the state Heslth Band is not scheduled undl Nov. 27.

in the latent developmeat, at least four marele of redtocedve weste were found buried outedde the dump. 


\section{Mile Island} probe 1 vote short of $\mathbf{N}$-ban

WASKIINGTON (UPI) - The president's Ture Mile Intand commistion, in closed meedags hat weekead, tell short of the ebeolute mifotity aeeded to recom. mend moratortum os construction of new auclar reactors li was reported Tuesing.

The New Yort Times atd two uniden. ufied comminedon members told it that six of these voting sapported the step, while thes of four oppoed th after latense de bate at a finl caries of meetlags.

But the propoes to balt construetion of new reactor did not become a formal recommeadation because a procedural rule adopted on Saturdny requires in abcolute majortty - seves votes - of the 12 coinintedones for such recommends. toes, It sald.

An NRC representative had ao comment Tueedsy on the Dewspaper report.

The Tlmes also sald it had obtuined an Oct. 17 draft of the commission's flual report, which is due to be submitted to President Carter early next week, and learned that the final version virtually is unchanged.

According to the psper, the commisction concludes is its final draft repor that the ottlity that operated the reactor "did not have suffictent knowledge, expertise and peronat to operate the plant or maintain it adequately."

The commission found that the total cost of the Three Mile Island reactor accident, including restoriog the plant and providing alternatdve electricity, would be blgb; ranging from $\$ 1.047$ billion to $\$ 1.858$ billion.
The druft report aloo was crittcal of the companies that made and designed the reactor. And the report charged the federil repulntory ageacy was preoceupted with tecendias resctors, not ascoring their anfety, and lacked a system "to measure and improve the quality or safety regulatoas."

The commiaston headed by John Kemeay wes ser up by Prostded Carter lest apring after the March 28 accident at the Three Male Iolnad auclear plant in Peno. sylvania It is ose of six groups exanining the lacideat and tis consequences.

The Times suld the commisston's formal recommendations iaciuded the following:

- That the flvo-member Nuclear Regulatory Commision, an independeat lederal agency, be abolisbed and replaced by an ageacy in the executive branct with a single director appointed by the presideat and conflimed by the Senate.

- That reactor operating licenses be subfect to periodic renewal after an open and public hearing on the performance of the operating utllity.

- A vartery of changes in the qualifica. tion of reactor operators. their training. the organization of reactor control rooms and the intensity and direction of govern. ment regulation. Al present, many aspects of reactor safety are left to the discretion of the companies that design and manufacture reactors and the utillties that operate them. 


\section{Bid for hearing on Trojan upheld}

SALDM - Oregon's Energy Facillty Siting Council must hold a hearing that could reoult in revoling or suspending the state perrail to operate the Trojan nucleap power plant, the Oregon Court of Appeals ruled Mondny.

The court sald the herring must be beld to condder the site cerdficate lasoned for the plant, near Rainier.

Two Porthand Democrats. state Sens. Jan Wyer and Ted Hillock, asked the Sitios Counell for a contented eas herr. ins on the certification of Tropan a re quext the counctl deviled.

Wyers and Hallock then took the mattor to Mulmomit County Cireut Conrt, whers Judge Churles Livithin found senins the counetl, a ruling it appenied.

In upbolaling the lower court's ruling. the appeals court suld the wor the comidis own filles, to is requilred to hold a bearing 0 requested by Wyers and Hil. boct.
The larmakers want the nenring to anpied or revole Trotan's ste certuficate. They contend Porthend.Genernl Electric Co. I storing wore spent foel rods - and for loager partods of time - then speci. fled to ite the certffeate, which also is a volatton of a state law that problbits eocubllatalas a waste disposal factlity for redionettre materials in Oregon, the lawmakess cointeand.

State law, anid the court, requires that a ats be und scoordine to its dite cartifi. eate.

State law aloo allows a waiver of that requirement by the oouncil. but only atter a public hearlng. And. according to Wyers' and Hallock's complaint, "No such hearing has been held and the owner is not ut!liatag Trojan in aceordance with its die certifleate."

"A hearlag must be beld." the court aded. 
Oregon Journal

Portland, Oregon

October 24, 1979

\section{S. Carolina N-dump restricted}

Uaited Press Intermational

South Carolina, the only state accepting low-level nuclear waste, bas ansounced it will bar any shipments of radioactive materials originaily intend. ed for recently closed dumps in Nevade and Washiagton state.
In Nevada, Cov. Robert List safd Tuesday that be is golag ahead with the shutdowe of the state's nuclear dump site - one of oxly three in the nation - despite mountlag pleas trom hospitals and research cen. ters to keep it open.

Nevada's trouble plagued dump in the desert near Bentry was ordered closed late Monday by List after four radinactive barrels were lound burted outside the property.

Llst also critleized President Carter, saying he is more interested in politics than in developing a as. tonal policy for the disposal of the auclear garbege. 


\title{
Brown's pledge to shut $N$-plant draws cheers
}

\author{
DURHAM. N.H. (UPI) - California \\ Gov. Edmund G. Brown Jr. brought \\ cheers trom 800 students at the Universi- \\ ty of New Hampshire Wednesday by \\ pledging to shut the $\$ 2.6$ billion Seabrook \\ nuclear power if \\ he's elected presi- \\ dent. \\ news \\ The Seabrook \\ plant. now under \\ construction, has \\ scope \\ been the target of tepeated anti-nuclear \\ demoastrations for the past three years. \\ More than 2,000 protesters tried to storm \\ the gates to the coastal plant earlier this \\ month, but were repulsed by police and \\ National Guardsmen. \\ Brown. al unarinounced candidate for \\ the Democratic presidential nomization. \\ repeated his call for a hait to construction \\ of new nuciear plants and pledged that he \\ will block the government from issuing a \\ license for the Seabrook plant if he's
} elected. 


\section{Trojan exercise taken seriously}

\section{Dy PAUL MANLY \\ and SPENCER HEINR \\ Joural Seaff Wrters}

Three hour loto Thursdey's practice drill for a Trojen power plent emergency, the dozen or so state offldaln and techaicians staffing the governor's command post. suddealy realtzed that no one bad remembered to arder a por of colfee.

That's bow sertously the exercise was taken in the crowded room in a corner of Portland's State Orflee Buflding where Cov. Vic Atlyeh buddled with representatves of Portiand General Electric Co. and Oregon's Health Diviston. Energy Department and the State Pollce.

The same group was scheduled to meet agala Friday, this dine at the Trojan Vistors Center, to ovalunte Thursday's drill and discuss where improvements might have been made if the "disaster" had been real.

THE "ALERT" that reached the goverwor's offlce in Selem at 10:08 a.m. Was not as much of a surprise as hed been planned. For weeks PGE, state and county emergercy services agencies had been planniag a tear of Trojan's emerzency plan for the week of Oct. 22, but the exict date was supposed to be s secret.

As it huppened, the Trojen Decommissioning Allines - which wants Trojan put out of cetton perminently cot word of the date and relayed the information to the Dews medis.

In that way the governor, too, found out which day be was going to be called on to mike dectistons about "eva. cunsting" redidents around Trojan, but be said he dida't know the exact timing of the exercise unthl State Police Dotified bls office of the siert four minutes after th wes recelved at pollice beadquarters in Salem.

The four-minute delay was necessary, the governor expinined, for the State Police to varify that the alen was "real."

CONTRARY to expectations when plans for the drill first were drafted. the exercise bad to be conducted while trojas was out of action, with the auclear resctor shut dows so that repairs could be made this week to a padr of leakd as steam turbines.

For that reason. the stuation at the governor's com. mand post became a bit unreal when reports came in Indicating that a control rod had broken and radlosettre ges hed been relensed lato the alr.

At the Trojan plant, 5 miles south of Rainier, the exerelae began at 9:59 em. when control room worters recelved as envelope that contalned the scearita.

Control room personnel phoned the attendant at the nearby Viator Center public information desk, and the annouaced over the public addreas oystem that as sceldent hed occurred.

SIRENS sounded and plant managers drove cars to the Vlators Ceoter auditorium. which would serve as a command and arategy cepter for the site in an actual emer. sency.

Within flve minutes, they were sented at a table with 11 telephoses hooked lato a ceatral, portable phose jack.

They evaluated scenario data and fed it to emergency agencles in the area.

Commend personnel kept a ronnigz tumetable posted to the wall of radiation readtags, evecuation times and ambolence artivals.
Ambulance persoanel removed a worker who, accord. ing to the scenarlo, hed bumped his head while trying to escape the "containment" area of the plant. He was admitted to Good Samuritun Hospital.

Arother worker, supporedly exposed to radiadon, was led through the decontamination chamber sod drives to Good Semaritun in a Portland Genesal Electric Co. car.

A US. ARMY Natlonal Gund bellcopter landed outadde the Vistiors Center. In an actud emergency. PGE apokesmen sald. the cratt would be dispatched to follow the plume of radlonctive geves.

Dave Eagon, a PGE public Information officer, ald the teat was worthwhile despite criticism from wome ant. anclear groups that the date of the teat was geatrally bown earlier is the week.

"But people at the plant didn't know exactly what dime of day It was going to bappen." Eagon ald. "And they dida't know the scenarto undl they got the en. velope."

Tom Mckenas, leader of the federal Nuclesr Raguln. tory Commission tesk force that observed the entire test. ald as it progressed that the response by Trojan and area coveraments seemed well-coordlinated.

"I SEE a lot of positive things," be suid.

"One of the things we wanted to determine was whether they had the ability to immediately locate an itrerait" to observe the plume.

The bellcopter was here right away. The crew was on the ball. They seemed to know fust what to do."

In Warhington's Cowlitz County, directly across the Columbla River from Trojan, restdents were advised lo evecunte from the dity of Kalime and the Green Moun. tain are. They were advised to bead for the Lewis River reglon if a real emergency developed.

The dmulnted eccident, Atyeh explained, lavolved a broken rod in Trojan's reactor that allowed steam to exape (an eveat that was impossible, because the pinnt was shut down and no steam was being generated.

"An amoust of steam has escaped outside the plant." Atyeh coatloued keeping a perfectly straight tace and ecting for all the world as if the most serious crisis of his term in office was seally bappeoiog.

THE FRST blat that the stuntion was anythiog less than a practice exercise came when Atyeh used the worde "evacuntion drill" to describe what the Columbia County shertifs offlce was Injtinting withid a 2.5-mike redius of Trojen.

"We've fust received word that they're asking that evecution be extended to 6 to 7 miles (from Trojan)," the povernor condrued. "We'tl let you know our decision on that"

For the aext 2/\% bours. Atyeh smoked cigareate after clgarette as reports poured into the command post from Trojen irom Health Diviston teams checking radiation levels at vartous distances from the pinat, from the Columble County emergency services office in St. Helens and the Cowllez County office la Kelso, Wash.

AS TDLPHONES rang. Featth Diviston and Energy Departmeat offlcials automattcally answered "Decidion Center" as if they did it every day.

The sovernor indited on beidg briefed about the rub fect of every phone communication and havias technical details "truaslated" by tecbnicians familine with radia. don and auclear generators. 
Orezon Journal

Portland, Oregon

Octoser 25, 1979

\section{Trojan emergency response tested}

A iest was staged T.uursday of emerrenci: responses in the event of a radlose live acident at the Trojen nuclear power plant.

The loir-hour test begen at 9:59 a.m. with emergency teams from Columbla Councy in Oregon and Cowlitz County in Waskiagton participating in the exercise.

Gor. Vic Atiyel's offloc in Salem was nottiled at 10:18 a.m. That a stmulated cccldent had occurred. The accident supposed ly Involved the brenting of pod, which released radionctivity toto the atmo-

Aur th Immedlately boerdet a hellcop-

Aus th immediately or ter and flew to Portiand, where he arrived at $11:$ o s.m. at a commend pont set up in the Suate Oifice daslaing Meanume, officlals and technlcians of the Oregon Health

Divialon and the Sute Department of En. ergy were too busy to b tel reporters on the extept of the supposed radiation rease ovacuation activities.

Atte: Atlyeh arrived and was.binefed on the slluation, be told the waiting re porter that the amount of radiation es caping cutside the plant was between one and five rems, explaining that five rems would equal the yearly radiation dose to an avernge Trojan employee.
The annual teat b conducted a a re zulrement of Portland General Elechic's peratlos llisense for the nuclear plan per Rinie- to show what menture would be taken to protect the public in case of a nuctear accident.

Juanite $G$ bson, secretary of John $T$ DeFrance. disector of emergency service or Columbia County, sald thelr first notication of the mock accident was ro celved at 10:: $3 \mathrm{am}$.

That call, she sald, was recelved Through the county's central dopatch netdulsed to sctivate our emergency re poose pinn.

"The call came from Trejen," she sald. "Our orders were to evacuato the 1/kmile radlus around Trojan - about 600 reseons." Atyeh announced at 11:30 \&.m. that a recommendation was recelved to expand the evacuation expand the evacustlon radius to olx

M. Gibson ald police went door to door in the rea, banding out eviaund isetructions, although lo reallty cobons was actually evecuated.

She suld PGE reported the "actagatriets volved "a bith releave of rediation on thetr 's' monitor. I don't know what the mears."
The people "evecuntid" wers tiventex

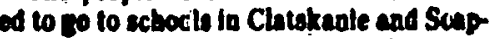
poosen Mi. Glosian calds.

"If at all potdble, boy were to use their own tranoportation," stre sald.

Me clbcon esed that ln a real emergen. cy. Matlonal Guard vehloles and ectiool buetes would be ueod in an evacration. These vehlcles were placed on alert Thuraday but not ectually seat out.

Peicono livir:e In Cowlitz Cosoty. Wash, fuat ecmos the Columble Ruer Irom Trojan, also were advised to evacur. ate in the simulution. Longriew, the cour ty sant of Cowinz County. is the largen city clocest to the buelear plant.

All pereons in Southwest Washiorton were lald to tuge thetr radios to 1270 on the AM dial to Isten for any emergency inworucements.

As the mete-belleve oxercts wis ento

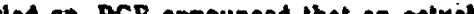
current ahutdown of Trojen is expected is

PGE

PCe arller planned to have malate ance and repalr worth completed by thlo weak and the plent back In operation ean ly next woek. 
Oregon Journal

Portland, Oregon

October 26, 1979

\section{Council takes first step toward N-plant decision}

By PAUL MANLYY

Jourall Steff Wrter

Oregon's Enerby Facility Siting Counedl took the first step Friday down a long roed toward final action on a proposal pending for aearly a decade to bulld two ouciear generators at Pebble Springs in Gilliam County.

With ao debite, the six members pres. ent at a meeting in Porthnd agreed that the four utility companies sponsoring the project beve proved they will make tho utmost practical use of any byproducts or wastes generated by the auclear project if it is ouilt.
There was no argument on that subject trom foes of the Pebble Spriags project who participated in state heartags that opanned more than a year.

"We have one (isaue) out of the way." exclaimed Councll Chairman Walter Evans triumphently as the motios passed unnimoudy.

Beneflcial use of wartes was one of four "hincontested" wbjects to be debated Fridry by the Sitng Coundl. Friday's seyclos was the firot of many pienoed by the councll for the coming year to review upwards of 20 rabjecte on while tertiono ay wes precented at the bouring. 


\section{'Decision center'} rapped on $\mathbf{N}$-drill

DY SPENCER HIINZ Jounnl Staff Wrter

RADNER - A spokesman for a federal agency Frtday criticized the effectrveness of the rate "decision ceater" office in Portland during the mock disater drill Thursday involving a supposed release of radiadod from the Trojas audicar powes plunt near here.

"When it comes to making dectistons, it appears that no dectsions were being made at the state decision ceater," Dick Donovan, a spokesman for the iederal Emergency Management Agency, told a packed anditorium during a cridque sesson at the Trojan Visitors Ceater.

The deciston center "ceased to function when the governor arrived. It simply stut down for 45 minutes," Donoren declared. Donoven's reference whs to confusion crented when Gov. Vic Adyeh artived by belleopter trom Salem to talie charge of the decidon center in the State Offlce Butlding aboat in bour after the drill be gng it 10 am.

The thrus of commeats by a panel of erport nhermer was that the dill hed been a sucees from the andpoint of 11 lustrating a amber of deficiencles.

The observers aid the drill had been belpiul in showtng better ways to provide for an emertincy in the foture. (Rebtad cary on page 31) 
By PAUL MANLEY

Joural Stat Writer

Portland General Electric Co. - and its ratepayers - are going to feel effects of last spting's Three Mile Island auclear mishap for some time to come.

Even though the most serious nuclear power piant accident in U.S. bistory occurred six moaths ago in Penusylvanila, tts impart will be noticed for years in Oregon and elsewhere is the nution, two utlity Industry spokesmen indleated Tuesday in Portland.

A.J. "Jeck" Pfister, director of the Salt River nuclear project in Arizon. and Joe Prestele, nuclear operations specialist for the Electric Power Research institute, described cooperative steps belag taked by the utdity industry to reduce chances of future nuclear mishaps and to protect the public and the utilities against the consequences of any that do occur.

With Portland General Electrtc Co. Board Chairman Frank M. Warten, they spoke to news reporters and invited representadves of the publlc in PGE's WII. inmette Center audirorium.

Warren suid PGE is planning to purdet. pate in a proposed insurance pool that would cover part of the cast of replucement electridty purchased during a long outage of a large generating plant.

Metropolitan Edison Co., the utlity that owned the stricken Three Mile Island plant, still out of commission. has had to pay more then $\$ 20$ million a month tor power to replace the output of the shutdown project:

Warren estimated PGE's share of the Insurance "premium" would be $\$ 1$ millioo to $\$ 2$ million a year. "We might have to contribute to (solving) their problems and they'd contribute to ours," he said, refer. riag to other utllities that would pertidi. pate in the pool.

Asked whether that expendture was reasonable for bis company, Warred replied that be considers it a good lavers. ment because a ode-day outage for PGE's Trojan auclear plant may cost $\$ 700,000$ to $\$ 900.000$.

The PGE chairman noted that the utitity Industry lnsurance plan is stin belag drated, but said be folt the comprny like by will seed the Oregon pubtlc utlity comind suloder's epproval to perticlples.

"T think we would get that approvar" Warren added. "It we did not, I thint-mo weill consider (partcipating) unytow," meaning that PGE would pay the biforance premium out of earnlage if . If coulda't be fastifled to the PUC as a biedness expense.

"But. we think tis a very proper so pense," Warrea tressed.

(Condaved os page 11) 


\section{$\star$ Three Mile 'fallout': Portlanders may pay}

(Coxtlaned trom page 1)

Pinter exdmated PGE's yearly coo- Iinuing for many yearz to determine what Utibution will be $\$ 150,000$ to the institute effects, If iny, the redioactive emisslions

of Nuclear Power Operatton (INPO) be will have on resldents of the area aronnd

will have on residents of the area around

nuclear generalors to Improve exchanges. EPRI, research and development

of Information and techniques in the au- organlzation funded by dectric utlitites, clear energy fleld.

also is putting together a team of experts

He suld one lesson learaed from Three to evaluate minor malfunctions at all au-

Mile Island is that "there Is wide disparity clear generators to see whether they pro-

In the operatlon of nuclear power plants."

The new INPO will "seek out the most haps.

eflectlve tralning technlques (lor nuclear

plant operators) and the best operallog land occurs. Plister sal1, the utllity can-

haps.

utilities, Pflater explaned.

land occurs. Plister sait, the utllity can
pany operating the plant will be able to

obialn from industry sources. inrough

Prentele sald the Electric Power Re-

INPO, the equipment and expert manpow.

search Institute is continulog its own er needed to cope with the problem.

analyds of the' Three Mile Island mishap. Warren sald some U.S. Nuclear Regula- too blg for the size of their work force, so they welcome help from the utility indus. try in Improving procedures ond exchanges of Information.

"The utlilty operating the (nuclear) plant has to be responsible for what happens there." the PGE chairman said.

He sald Innancial elfects of the Three Mile Island mishap on Metropollian Edl. son Co. "give the greatest motivation" to all utilities to operate nuclear generators as expertly as possible.

Any lime disaster of Three Mile Istand scope occurs, "the entire nuclear industry Is in danger." Pilster commented, explainscing the industry concern for preventine a repetition.

He sald the accldent "has been costly in terms of public support."

Warren is one of elght members of : national utility industry committee studying effects of Three Mile Island. 